UNIVERSIDADE DE BRASÍLIA

INSTITUTO DE CIÊNCIAS HUMANAS

DEPARTAMENTO DE SERVIÇO SOCIAL

TRABALHO DE CONCLUSÃO DE CURSO

ORIENTADORA: PROFa. MSC. PATRÍCIA PINHEIRO

A CAPACITAÇÃO DOS PROFISSIONAIS EM REFORMA PSIQUIÁTRICA

COMO ESTRATÉGIA PARA A IMPLEMENTAÇÃO DE SERVIÇOS

SUBSTITUTIVOS NO ÂMBITO DO HOSPITAL SÃO VICENTE DE PAULO

GRACE ANTUNES

BRASÍLIA 
GRACE ANTUNES

A CAPACITAÇÃO DOS PROFISSIONAIS EM REFORMA PSIQUIÁTRICA COMO ESTRATÉGIA PARA A IMPLEMENTAÇÃO DE SERVIÇOS SUBSTITUTIVOS NO ÂMBITO DO HOSPITAL SÃO VICENTE DE PAULO

Monografia apresentada ao Departamento de Serviço Social da Universidade de Brasília como parte dos requisitos para obtenção do grau de Assistente Social, sob a orientação da Prof. ${ }^{a}$ Msc. Patrícia Pinheiro 


\title{
A CAPACITAÇÃO DOS PROFISSIONAIS EM REFORMA PSIQUIÁTRICA COMO ESTRATÉGIA PARA A IMPLEMENTAÇÃO DE SERVIÇOS SUBSTITUTIVOS NO ÂMBITO DO HOSPITAL SÃO VICENTE DE PAULO
}

\author{
Por \\ Grace Antunes
}

Monografia apresentada ao Departamento de Serviço Social da Universidade de Brasília como parte dos requisitos para obtenção do grau de Assistente Social, sob a orientação da Prof. ${ }^{a}$ Msc. Patrícia Pinheiro

10 de dezembro de 2007.

\section{Banca Examinadora}

Prof. ${ }^{a}$ Msc. Patrícia Pinheiro

Prof. Mário Ângelo Silva

Maria da Anunciação Soares Castro Alves 
“Onde está o sábio? Onde, o escriba? Onde, o inquiridor deste século? Porventura, não tornou Deus louca a sabedoria do mundo?” Apóstolo Paulo 


\section{Agradecimento}

Em primeiro lugar, agradeço a Deus, meu Pai, por me capacitar e sustentar não apenas na construção desse trabalho, mas em toda a minha vida. O Teu amor e paciência me motivam a ser melhor; mesmo quando não tiver nada, terei tudo, pois tenho a Ti.

Agradeço à toda minha família, especialmente, às minhas irmãs Corem, Loreta e Kate, e à minha mãe, pelo apoio em toda a minha trajetória acadêmica; por levantar mais cedo pra fazer o café da manhã; por acreditar contra as circunstâncias que esse sonho seria possível; por nunca ter desistido. Essa vitória também é sua.

Agradeço ao Guga, meu companheiro de todas as horas, amor da minha vida, e que me faz acreditar a cada dia no meu potencial e na possibilidade de ser cada vez mais feliz. Obrigada pela sua ajuda na correção deste trabalho, e pela compreensão em tantos momentos. Amo-te, Amorebo!

Agradeço à professora Patrícia Pinheiro, por me orientar na construção deste trabalho, e também aos professores do Departamento de Serviço Social Karen Santana, Denise Bomtempo, Luiz Fernando Viegas e Maria Lúcia Pinto Leal, que contribuíram efetivamente para minha formação.

Agradeço de forma especial à Maria da Anunciação, minha supervisora de estágio, que me mostrou como ser uma profissional engajada e comprometida com os direitos sociais. Agradeço também à equipe do Programa Vida em Casa, em especial ao Oliveira, à Lenita, ao Mário, ao Maurício, e todos que tanto me ensinaram.

Agradeço às grandes amigas Jamila Zgiet e Carla Soares pela atenção especial na correção de algumas partes deste trabalho. Vocês foram essenciais. Agradeço também aos meus amigos, futuros colegas de profissão, Wênia Oliveira, Luana Regina, Thaís Imperatori, Michele Lago, Leiliane Morais, Elen Martins, Alex Kid e Fabiana Sena, além de todos aqueles que estiveram comigo nessa jornada.

Agradeço à minha família de Deus, líderes, discípulos e irmãos, pela compreensão de tantas ausências e, principalmente, pelas orações. Vocês são especiais $\left(\mathrm{D}^{+}\right)$pra mim, especialmente, minha grande amiga Ana Carolina Sousa do Vale.

Sigo na perspectiva de que muito maiores que os meus, são os sonhos de Deus pra $\operatorname{mim}=$ )

A todos aqueles que fizeram parte dessa conquista, o meu muito obrigado! 


\section{Resumo}

As instituições psiquiátricas, historicamente, carregaram a função de controle e repressão social, pois eram destinadas a todas as pessoas indesejadas pela sociedade, e não apenas àquelas que possuíam transtorno metal. A partir da década de 60, surgiram novas perspectivas de atenção à saúde mental que negavam o modelo manicomial vigente, como a antipsiquiatria inglesa e a desinstitucionalização italiana. No Brasil, no contexto da reabertura democrática e da emergência dos movimentos sociais pela Reforma Sanitária, trabalhadores da saúde mental, juntamente com a população, passaram a reivindicar a regulamentação de um novo modelo de atenção às pessoas com transtorno mental. Esse foi consolidado a partir da Lei 10.216/01, que estabeleceu a extinção dos hospitais psiquiátricos e a substituição desses por serviços de caráter comunitário e que, além de oferecer atendimento integral a essas pessoas, garantissem a sua cidadania. Em várias partes do país, a rede de saúde mental encontra-se bem estruturada, realidade que não define o atendimento do Distrito Federal, onde a Reforma Psiquiátrica ainda está no início de sua implementação. Entre os serviços de saúde mental disponíveis no Distrito Federal, está o Hospital São Vicente de Paulo, considerado uma instituição psiquiátrica fora dos parâmetros estabelecidos pela legislação. No entanto, dentro dessa instituição funcionam alguns serviços pautados pelos princípios do modelo psicossocial de atenção, implementados por iniciativa dos profissionais.

O objeto deste estudo é investigar a relação entre a capacitação em Reforma Psiquiátrica e a implementação de serviços substitutivos no âmbito desse hospital. Para atender a este propósito foram aplicados, em abril de 2006, questionários aos profissionais de diversas áreas do Hospital São Vicente, a fim de conhecer qual o nível de conhecimento que esses se atribuíam sobre o novo modelo de atenção à saúde mental, e avaliar a sua participação em eventos e cursos de capacitação nesse tema. Além disso, foram realizadas entrevistas com os profissionais responsáveis pelos serviços dentro do hospital, verificando-se que todos já participaram de ações de capacitação em Reforma Psiquiátrica, e fazem parte das mesmas categorias já citadas. Uma dessas entrevistas forneceu dados sobre a estruturação da Reforma Psiquiátrica no Distrito Federal atualmente, mostrando que esse tema ainda é palco de discussões no âmbito político, e que possui vários obstáculos para sua efetiva implementação.

Palavras-chave: saúde mental; capacitação profissional; Reforma Psiquiátrica; serviços substitutivos; desinstitucionalização; transtorno mental. 


\section{Lista de Siglas e Abreviaturas}

\section{Siglas}

AFAGO - Associação de Familiares, Amigos, Usuários e Profissionais da Saúde Mental BPC - Benefício de Prestação Continuada

CAPS - Centro de Atenção Psicossocial

CAPS-ad - Centro de Atenção Psicossocial especializado em Álcool e Drogas

CAPS-i - Centro de Atenção Psicossocial infanto-juvenil

CF/88 - Constituição da República Federativa do Brasil de 1988

CNS - Conferência Nacional de Saúde

CNSM - Conferência Nacional de Saúde Mental

COMPP - Centro de Orientação Médico- Psicopedagógica

COSAM - Coordenadoria de Saúde Mental

DF - Distrito Federal

FHDF - Fundação Hospitalar do DF

GAPI - Grupo de Assistência Pós- Internação

HBDF - Hospital de Base do Distrito Federal

HDIA - Hospital O Dia

HPAP - Hospital de Pronto Atendimento Psiquiátrico

HRT - Hospital Regional de Taguatinga

HSVP - Hospital São Vicente de Paulo

INAMPS - Instituto Nacional de Assistência Médica da Previdência Social

INSS - Instituto Nacional do Seguro Social

ISM - Instituto de Saúde Mental

LBHM - Liga Brasileira de Higiene Mental

LOAS - Lei Orgânica da Assistência Social

MNLA - Movimento Nacional de Luta Anti-manicomial

MTSM - Movimento dos Trabalhadores da Saúde Mental

ONG - Organização Não Governamental

PSF - Programa Saúde da Família

PVC - Programa Vida em Casa

SES/DF - Secretaria de Estado de Saúde do Distrito Federal

SRT - Serviço Residencial Terapêutico

SUS - Sistema Único de Saúde

UNB - Universidade de Brasília

\section{Abreviaturas}

Art. por artigo 


\section{Lista de Gráficos}

Gráfico I - Idade dos profissionais questionados (p. 61).

Gráfico II - Tempo de serviço no HSVP dos profissionais questionados (p. 61).

Gráfico III - Seção de atuação dos profissionais questionados (p. 62).

Gráfico IV - Profissão das pessoas questionadas (p. 63).

Gráfico V - Sexo dos profissionais questionados (p. 64).

Gráfico VI - Nível de conhecimento dos profissionais em Reforma Psiquiátrica (p. 65).

Gráfico VII - Participação em eventos sobre a Reforma Psiquiátrica (p. 66).

Gráfico VIII - Nível de interesse em conhecer a Reforma Psiquiátrica (p. 68).

Gráfico IX - Disponibilidade de horas semanais para capacitação (p. 68).

Gráfico X - Nível de conhecimento por categoria profissional (p. 69).

Gráfico XI - Nível de interesse por categoria profissional (p. 71).

Gráfico XII - Participação em eventos por categoria profissional (p. 72).

\section{Lista de Quadros}

Quadro 1 - Eventos informados pelos profissionais (p. 66).

Quadro 2 - Auto-Avaliação do conhecimento dos profissionais (p. 70).

Quadro 3 - Atuação das equipes do Setor de Terapia Ocupacional da Internação dividido por atividades (p. 80).

Quadro 4 - Profissional que implementou o serviço (p. 92). 


\section{Sumário}

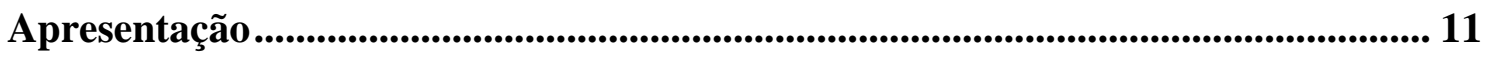

Capítulo I - A Instituição Psiquiátrica - Concepções e Princípios ............................ 12

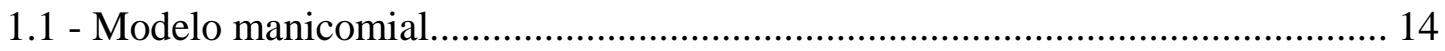

1.1.1- Funções históricas do hospital psiquiátrico................................................... 18

1.1.2 - O hospital psiquiátrico como instrumento de controle e repressão social ... 19

1.1.3 - Relações de poder na instituição psiquiátrica ............................................... 20

1.1.3.1- Níveis de hierarquia ente profissionais ................................................ 22

1.1.3.2 - Relação profissionais - pacientes ........................................................ 23

1.2 - Modelo psicossocial de atenção à saúde mental .............................................. 25

1.3 - Reforma Psiquiátrica internacional: antipsiquiatria e a desinstitucionalização . 26

Capítulo II - Construção da Reforma Psiquiátrica no Brasil e no DF ..................... 31

2.1 - Saúde mental no Brasil antes da reforma ............................................................ 31

2.2 - Surgimento da reforma psiquiátrica no Brasil.................................................... 37

2.2.1 - Reforma psiquiátrica no contexto da reforma sanitária ............................... 38

2.2.2 - Movimentos pela construção do modelo antimanicomial........................... 40

2.3 - Política de Saúde Mental na atualidade............................................................. 44

2.3.1 - Marcos legais da implementação da Política de Saúde Mental ................... 45

2.4 - Reforma Psiquiátrica no Distrito Federal........................................................... 50

2.4.1- Construção da Reforma Psiquiátrica no Distrito Federal............................. 50

2.4.2 - O Hospital São Vicente de Paulo ..................................................................... 54

Capítulo III - Pesquisa de Campo ................................................................................................. 58

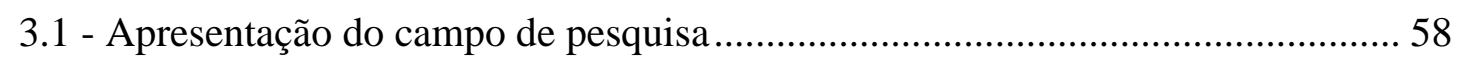

3.2 - Objetivos da pesquisa e metodologia utilizada .................................................. 59

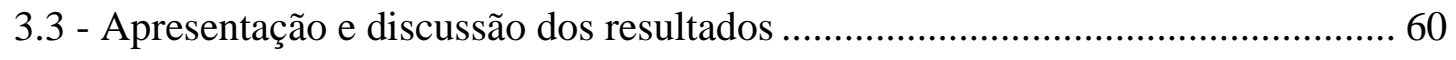

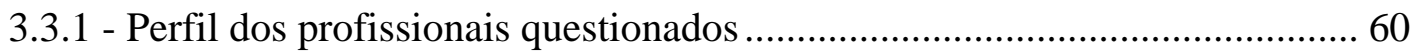

3.3.2 - O conhecimento dos profissionais sobre a Reforma Psiquiátrica e a participação destes em eventos que tratam desse tema .......................................... 64

3.3.3 - Serviços implementados por iniciativa de profissionais do HSVP .............. 73

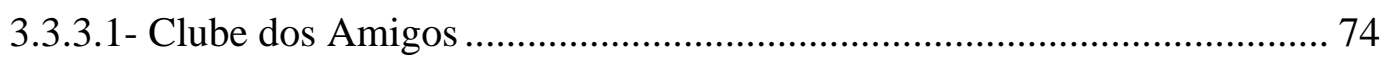

3.3.3.2 - Time de Futebol Nacional Esporte Clube ............................................. 75

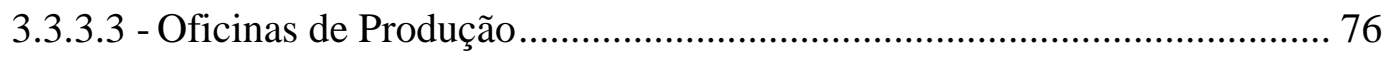


3.3.3.4 - Setor Terapêutico Ocupacional - Internação.......................................... 78

3.3.3.5 - Grupo de Atendimento Pós-Internação (GAPI) ..................................... 83

3.3.3.6 - Grupo de Terapia Comunitária ............................................................ 85

3.3.3.7 - Programa Vida em Casa (PVC)............................................................ 87

3.3.4 - Comparativo entre os resultados …............................................................ 91

3.4 - Acontecimentos recentes na saúde mental do DF ............................................. 93

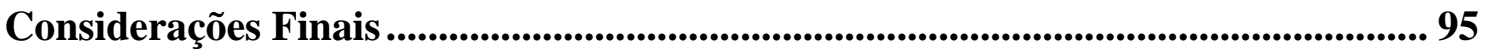

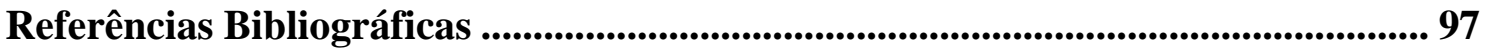

Apêndice

- Questionário de pesquisa (Público-alvo: profissionais do Hospital São Vicente de Paulo);

- Roteiro de entrevista semi-estruturada (Público-alvo: profissionais que implementaram Serviços Substitutivos no âmbito no Hospital São Vicente de Paulo). 


\section{Apresentação}

A Reforma Psiquiátrica, que estabelece a construção de um novo modelo de atenção em saúde mental, ainda não foi efetivamente implementada no Distrito Federal por meio dos serviços substitutivos. Ao contrário disso, ainda existem nessa unidade da federação instituições como o Hospital São Vicente de Paulo, o qual, de acordo com a legislação deveria ter sido extinto, por se constituir num hospital psiquiátrico,.

Embora o atendimento desse hospital não esteja totalmente pautado pelos princípios da Reforma, existem alguns serviços baseados na perspectiva do modelo psicossocial, implementados por iniciativa dos profissionais dessa instituição. Este trabalho busca conhecer quais são esses serviços, e estabelece como objeto de estudo a importância da capacitação dos profissionais em Reforma Psiquiátrica para a implantação dos mesmos, no âmbito de uma instituição que carrega o caráter do modelo manicomial de atendimento.

Dessa forma, para compreender essa relação, primeiramente foi realizada pesquisa bibliográfica que possibilitasse estabelecer um paralelo entre o modelo manicomial e o modelo psicossocial de atenção à saúde mental, mostrando sua construção histórica. Também foi feito um levantamento e estudo da legislação vigente no país nesse tema, para avaliar a coerência dos serviços oferecidos pela instituição pesquisada com as novas diretrizes estabelecidas.

Em um segundo momento, foi realizada pesquisa de campo no Hospital São Vicente de Paulo, dividida em duas fases: a primeira, em abril de 2006, com a aplicação de questionários aos profissionais sobre capacitação em Reforma Psiquiátrica; e, a segunda, por meio de entrevista semi-estruturada com os profissionais que implementaram os serviços substitutivos no âmbito da instituição.

Esse trabalho está dividido em três capítulos. O primeiro fará um paralelo entre o modelo manicomial e o psicossocial, a partir da caracterização histórica da instituição psiquiátrica e dos movimentos que surgiram contrários a essa perspectiva. No segundo capitulo é traçada a trajetória da Reforma Psiquiátrica no Brasil e no Distrito Federal, evidenciando a participação dos movimentos sociais nesse processo. O terceiro capítulo abordará a pesquisa de campo realizada, apresentando-se e discutindo-se os resultados. 


\section{Capítulo 1}

\section{A Instituição Psiquiátrica - Concepções e Princípios}

No decorrer da história é possível identificar construções sociais acerca das doenças que são caracterizadas por estigmas, uma vez que está definido entre a cultura, a economia, a política e a ordem social, o que é aceitável ou não diante dos papéis que devem ser desenvolvidos na sociedade.

A construção do transtorno mental ${ }^{1} \mathrm{e}$ sua institucionalização a partir da Psiquiatria resultou de um longo processo de representações sociais e médicas em torno da loucura, tendo em vista os vários contextos políticos, econômicos e sociais pelos quais passou até chegar ao que é hoje.

A loucura foi interpretada de diversas formas ao longo da história, explicada através de paradigmas pré-científicos, metafísicos e mágico-religiosos, sendo atribuída ao castigo dos deuses, possessões demoníacas, entre outras interpretações. Antes do nascimento de uma ciência específica que a estudasse, as soluções para o transtorno mental eram baseadas em conhecimentos e práticas ancestrais, muito enraizadas na cultura das populações. Entre essas soluções estava a exclusão dessas pessoas nas instituições asilares. (GONÇALVES, 2004).

A sociedade da Idade Média tratava o louco como um indivíduo indesejado, privando-o da participação na sociedade; seu discurso era desprezado e abafado pelo confinamento. (FILHO, 1987).

Com o desaparecimento da lepra no Ocidente, houve o esvaziamento das instituições que segregavam os portadores dessa doença. Gradativamente, os leprosários passaram a recolher todas as pessoas que ofereciam algum risco à sociedade, como os portadores de doenças venéreas, os mendigos, e os loucos. (AMARAL, 2006).

A loucura era tratada como caso de segurança pública, de forma que as pessoas com transtorno mental eram retiradas das ruas e aglutinadas nessas instituições sem nenhum tratamento específico para sua patologia. O objetivo da internação era preservar a ordem pública, como afirma Castel (1978) mostrando o exemplo da França, onde o poder real, "munido das prerrogativas do executivo ele intervinha para salvaguardar a

\footnotetext{
${ }^{1}$ Embora a diferenciação de termos como doença mental, deficiência mental ou intelectual e transtorno mental não seja nítida, será utilizado neste trabalho o termo "transtorno mental", tendo em vista sua exclusividade na legislação brasileira atual sobre a saúde mental, a Lei 10.216/01.
} 
ordem pública contra as perturbações causadas pelos insanos.” (CASTEL, 1978: 2324).

De acordo com o autor, três coisas podiam acontecer ao louco, dependendo de sua condição familiar e relações sociais: a) a família poderia se responsabilizar totalmente por ele, mas teria que assumir a tarefa de neutralizar suas crises, para que não representasse risco à sociedade; b) quando a família não queria a presença da pessoa com transtorno mental em casa por essa não se submeter ao seu controle ou por representar riscos ao patrimônio da família, poderia solicitar juridicamente a internação do louco em hospital psiquiátrico, ou pedir a interdição judicial desse. Neste caso, todos os seus bens passavam para a família, alternativa escolhida em maior número pelas famílias mais ricas; também era possível pedir a internação em instituição particular, dispondo-se a família a pagar por ela; e, c) a pessoa com transtorno mental encontravase fora do ambiente familiar por ter fugido de casa, ou por não ter vínculos familiares; essa era internada compulsoriamente, o que representava a grande maioria das internações. (CASTEL, 1978).

Até o fim do século XVIII, a medicina ainda não tinha se interessado pela condição de saúde da pessoa com transtorno mental. No entanto, à medida que crescia o número dessas pessoas convivendo nos asilos, a possibilidade de observar as várias características de cada uma impulsionou o nascimento da Psiquiatria. (MACHADO, 2006).

Essa especialidade médica nasceu vinculada ao poder burguês, que surgiu com a Revolução Francesa, a partir do qual se estabeleceu na sociedade a regulação da vida social por meio do contrato social. Filho (1987) afirma que, nesse contexto:

[...] o discurso médico rompe com uma tradição individualizada de sua prática e se configura como prática social. Inicialmente socializando o corpo, em função das forças produtivas; posteriormente se organizando sob a forma de aparelho de estado, exercendo controle sobre a vida dos indivíduos, reforçando o poder estatal através de uma estratégia biopolítica. (FILHO, 1987: 78).

Foi de dentro dos asilos destinados a resolver o problema da pobreza que nasceu a Psiquiatria como uma prática filantrópica exercida pelos médicos, com o objetivo de manter os loucos confinados num local específico que possibilitasse o estudo do seu transtorno, além de proteger a ordem social. (SERRANO, 1992). 
O transtorno mental, nessa época, era estudado individualmente, sob a perspectiva biomédica de que era causado por alterações físicas, ignorando-se os determinantes sociais e culturais envolvidos. (GONÇALVES, 2004).

\section{1- Modelo manicomial}

Os antigos asilos destinados a recolher todas as pessoas que contrastavam com o modelo de regras sociais emergente permaneceram com a mesma perspectiva: excluir da sociedade essas pessoas; no entanto, com o advento da Psiquiatria para estudar os comportamentos disfuncionais da sociedade, esses passam a ser considerados instituições psiquiátricas, ou popularmente chamadas, hospícios. (MOREIRA, 1983).

Nessas instituições eram aplicadas diversas formas de tratamento, a fim de se analisarem os efeitos que determinados instrumentos tinham sobre a loucura; sendo assim, os pacientes que residiam nos hospícios, "eram acorrentados em seus leitos, submetidos a choques térmicos, elétricos, insulínicos e outras ações violentas, ou permaneciam ociosos, perambulando pelos pátios”. (MACHADO, 2006: 9).

Em 1793 o médico francês Philippe Pinel foi nomeado diretor do hospital La Bicêtre, um grande hospício francês onde se reproduziam estas práticas. Pinel percebeu a particularidade da loucura, separando as pessoas com transtorno mental das demais que conviviam no mesmo ambiente, para que pudesse tratá-las especificamente. Inspirado pela ideologia libertária da Revolução Francesa, tinha o objetivo de soltar os grilhões dos loucos e educar sua vontade, a partir do que ele chamou de tratamento moral $^{2}$, o qual reproduzia a tentativa de disciplinar e domesticar o louco, permanecendo a concepção deste como anormal. (SERRANO, 1992).

No entanto, as idéias positivistas emergentes no meio do século XIX fizeram retroceder a perspectiva do tratamento moral, e a loucura voltou a ser considerada um processo apenas orgânico, uma doença física. Essa visão do transtorno mental desvinculava-o de qualquer relação com os aspectos sociais, econômicos, ambientais e culturais da pessoa acometida, sendo esta considerada um "aparelho estragado", que deveria ser retirado do convívio social, se não houvesse tratamento para sua doença. (TEIXEIRA, 1993: 52).

\footnotetext{
${ }^{2}$ De acordo com SERRANO (1992), o tratamento moral baseava-se na perspectiva de educar a vontade da pessoa com transtorno mental, desenvolvendo a disciplina da mente.
} 
O positivismo, o qual determina que a compreensão do fenômeno pode ser alcançada a partir da análise de suas partes, influenciou o nascimento da corrente médico-biologicista, que passou a considerar o homem reduzido à sua condição biológica. (MACHADO, 2006).

Foi nessa perspectiva que a Psiquiatria encontrou suas bases de cientificidade, "buscando no próprio fenômeno da loucura suas causas e seus efeitos, privilegiando uma abordagem fundamentalmente biologicista, destacando nela os sinais e sintomas do adoecimento.” (MACHADO, 2006: 8).

As idéias positivistas carregavam em si o pilar da neutralidade científica, o qual permitia que a Psiquiatria focasse seu estudo e tratamento diretamente no transtorno do indivíduo, desconsiderando os demais aspectos determinantes da sua condição. Como afirma Machado (2006):

Era possível fechar os olhos para as dimensões histórica, cultural e social do sujeito louco, submetendo-o a tudo o que apraz a medicina moral e toda sorte de abusos cometidos em seu nome, na tentativa de trazer o doente de volta do desvio à norma, tendo o asilo como palco dessas práticas. (MACHADO, 2006: 10).

Com o advento do capitalismo, as relações de produção passaram a se estabelecer na exploração da força de trabalho e na lógica da máxima produção, alterando as concepções na sociedade, uma vez que a valorização da pessoa passou a ser estabelecida pela sua capacidade produtiva; esta última está diretamente ligada à sua condição de saúde, a qual era entendida, nessa época, como ausência de doença. (MACHADO, 2006).

No âmbito da saúde mental, essa perspectiva, aliada ao poder médico, justificou a exclusão e o isolamento das pessoas com transtorno, baseando-se na idéia da incapacidade para o trabalho; consequentemente, no século XVIII a prática de internamento passou a ser mais difundida.

O modo de produção capitalista fragmenta o homem, na medida em que tira do trabalhador a propriedade e a subjetividade sobre o trabalho que desempenha, fazendo deste apenas uma extensão da máquina que opera. De acordo com Machado (2006):

Nas instituições manicomiais, a fragmentação acontece de parte a parte, se, por um lado, o trabalhador, em sua ação, é privado da totalidade do sentido do seu trabalho, o sujeito louco, antes do trabalhador, já sofrera fragmentação maior, quando foi desapropriado de si mesmo, quando o manicômio primeiro o reduziu a corpo doente e quando depois jogou fora tudo o que lhe pertencia 
e que não estava contido em seu corpo, a saber, sua dimensão histórica e sociocultural. (MACHADO, 2006: 11).

Essas relações capitalistas surgem no âmbito das fábricas, com a industrialização, causando um grande aumento no contingente populacional urbano, à medida que as pessoas do campo migravam para as cidades em busca de melhores condições de trabalho. Nesse contexto, as instituições psiquiátricas passaram a abrigar, além dos loucos, todas as pessoas que não conseguiram acompanhar as exigências capitalistas, ou que não puderam ser absorvidas pelo mercado e ficaram sem renda e nenhum tipo de assistência à sua pobreza.

O objetivo terapêutico do hospital psiquiátrico acabou sendo ultrapassado pelas necessidades que se apresentaram, fazendo que este cumprisse um papel repressor, de retirar do convívio social as pessoas para as quais não existia tratamento delimitado, mas que eram indesejadas pela sociedade. (MOREIRA, 1983).

Não só a doença biológica agora definia a loucura, mas todos os comportamentos desviantes do padrão da sociedade. Como afirma Machado (2006):
Em que pesem os aspectos biológicos, um dos determinantes para a constatação da alienação é justamente a incapacidade do sujeito para o trabalho. O rótulo da incapacidade somado ao da periculosidade são os dois principais estigmas impostos ao portador de sofrimento mental. (MACHADO, 2006: 12).

Diante desse quadro, o modelo manicomial se define pela consideração do louco e da loucura como objetos de estudo da ciência médica, à qual é atribuído o poder e a supremacia sobre a pessoa com transtorno mental, e legitima a instituição psiquiátrica, no modelo asilar, como o espaço próprio de tratamento e medicalização dessas patologias.

No modelo manicomial, o internamento compulsório, o isolamento social e o ócio fazem o interno perder as suas capacidades criativas e habilidades, tornando-o dependente do manicômio, ou seja, institucionalizado, submetido às ações disciplinadoras e controladoras da instituição. (MACHADO, 2006).

Como afirma Goffman (2007):

Uma vez que o internado seja despojado de seus bens, o estabelecimento precisa providenciar pelo menos algumas substituições, mas estas se apresentam sob a forma padronizada, uniformes no caráter e uniformemente distribuídas. Tais bens substitutos são claramente marcados como pertencentes à instituição e, em alguns casos, são recolhidos em intervalos regulares para, por assim dizer, serem desinfetados de identificações. (GOFFMAN, 2007: 27-28). 
Ou seja, dentro do hospital, os pacientes eram padronizados, retirando destes suas identidades e particularidades, submetendo todos ao mesmo tratamento, colocando todas as doenças dentro de um mesmo espectro de análise, como se a loucura fosse a característica comum a todos, que neutralizava as diversas manifestações das suas patologias. No fim das contas, não havia tratamento eficaz: apenas medidas de contenção e manutenção destes pacientes.

Além disso, o hospital psiquiátrico retirava do paciente seu contato com o mundo externo; em primeiro lugar, pela distância da instituição dos centros urbanos e das casas dos pacientes, os quais eram distribuídos mais em detrimento das vagas existentes que pela proximidade de sua moradia. O contato com os familiares era restrito a dias e horários específicos, o que dificultava muitas vezes a visita desses. Em segundo lugar, a própria estrutura do hospital, com muros altos, portas fechadas, barreiras intransponíveis, revelava o caráter de isolamento e dissociação com o mundo externo, fazendo que os pacientes mais facilmente incorporassem a realidade do hospital como sua própria e se tornassem menos aptos para assumirem seus papéis sociais no mundo externo. (MOREIRA, 1983).

Todos esses aspectos mostram como a saúde mental, antes da Reforma Psiquiátrica, estava confundida com elementos de repressão e controle social, e não oferecia condições concretas de tratamento para as pessoas com transtorno mental, que lhes garantisse a reinserção social sem ferir sua identidade e liberdade. Pelo contrário: o hospital psiquiátrico levava as pessoas ali internadas à institucionalização, uma vez que, com a indefinição das internações, o longo tempo passado dentro da instituição, o abandono por parte da família, o uso abusivo de medicação, e a falta de tratamento terapêutico acabavam retirando das pessoas sua identidade, sua perspectiva de vida fora da instituição, e fazendo-as adaptar-se ao ambiente hospitalar. (MOREIRA, 1983).

Com o avanço da Psiquiatria e as alterações nos valores sociais, começou-se a considerar o transtorno mental inserido no seu contexto social, o que se ampliou após a Segunda Guerra Mundial, quando foram geradas profundas reflexões sobre as relações humanas e, também, sobre as representações da loucura na sociedade. 


\subsection{1- Funções históricas do hospital psiquiátrico}

Algo que bem explicita a contradição entre a teoria e a prática desenvolvida nas instituições, de forma geral, é a análise dos objetivos traçados formalmente em contraste com a realidade cotidiana.

Em relação à instituição psiquiátrica, de acordo com Moreira (1983), “o hospital psiquiátrico é uma organização que presta serviços para pessoas, propondo-se à tarefa de transformá-las, retirando-as de seu estado de doença ou incapacidade”. (MOREIRA, 1983: 18).

Historicamente, as tarefas principais do hospital psiquiátrico eram o desenvolvimento de técnicas que visassem à recuperação da saúde e a socialização dos pacientes, fazendo-os internalizar as normas de convivência da microssociedade que representava o hospital - tais como a obediência à hierarquia e a aceitação da possibilidade de contenção - para mais tarde reintegrarem-se na sociedade mais ampla. Estes eram os objetivos terapêuticos da instituição. (MOREIRA, 1983).

Diva Moreira ainda aponta outros três objetivos que fizeram parte da construção das funções do hospital psiquiátrico: a) a proteção da família, da comunidade e do paciente contra o mal que este pode realizar, pois, socialmente estabelecido, a perda da razão consistia na incapacidade da pessoa em determinar seus atos, podendo tornar-se perigosa à sociedade; b) a custódia ou abrigamento de pacientes crônicos, daqueles que perderam os laços familiares, ou até mesmo cujas famílias são incapazes de manter em casa uma pessoa improdutiva ${ }^{3}$. Dessa forma, o hospital psiquiátrico assume muito mais a função de prover alimentação, moradia e vestuário para esses pacientes, que a de promover sua saúde e recuperação; e, c) a formação e treinamento dos profissionais, podendo reproduzir nestes a ideologia interna já vigente no hospital, a qual será explicitada na continuação ou não das práticas institucionais já estabelecidas. (MOREIRA, 1983).

Outra função distinta do hospital psiquiátrico era a de internação de pacientes com doenças clínicas, os quais, sendo tratados nos hospitais gerais por comportamentos de ansiedade, depressão ou nervosismo, eram transferidos para o hospital psiquiátrico para serem tratados. Este último não possuía os recursos, materiais e médicos

\footnotetext{
${ }^{3}$ Entende-se o emprego dessa palavra nesse texto como a não-obtenção de renda por parte do paciente, que pudesse vir a somar no orçamento familiar.
} 
especializados para tratar esses pacientes em relação às outras patologias, os quais ficavam sendo transferidos de um para outro hospital até que tivesse a saúde restabelecida, ou até que, por tanta demora no atendimento e remoção do paciente, o mesmo chegasse a óbito. (MOREIRA, 1983).

\subsection{2- O hospital psiquiátrico como instrumento de controle e repressão social}

Além dessas funções formalmente delimitadas do hospital psiquiátrico, está uma das suas principais atribuições sociais, como foi construído historicamente: o controle da ordem social.

A Psiquiatria carregou essa função pela própria especificidade de sua área de conhecimento, pois tem como objeto as falhas ou rupturas que ocorrem entre o padrão de comportamento esperado socialmente e o expressado pelo indivíduo, onde deve intervir para restabelecer o equilíbrio das relações sociais. (MOREIRA, 1983).

A própria avaliação dos resultados do tratamento é feita na observação da capacidade de reintegração social do paciente, tendo em vista a normalização do indivíduo, sendo desconsideradas as particularidades de sua personalidade.

Moreira (1983) afirma que o hospital psiquiátrico, historicamente, assumiu a função de custódia e abrigo para as pessoas com transtorno mental, herança da antiga função do hospital de retirar das ruas as pessoas indesejadas pela sociedade. Essa função é considerada por Diva Moreira como preventiva, uma vez que estarão encarcerados aqueles indivíduos passíveis de cometer crimes nas ruas:

Com uma incapacitação que não lhes permite ser absorvidos pelo mercado de trabalho - o que poderia discipliná-los - sua internação vai significar a possibilidade de submetê-los à disciplina médica, além de, simultaneamente, proteger a cidade dos elementos passíveis de provocar a desordem pública. Não é por acaso que o hospital psiquiátrico é considerado pela família, prefeitura e polícia, ou pela sociedade em geral, como instituição alternativa de controle social. (MOREIRA, 1983: 66-67).

Os hospitais psiquiátricos também eram considerados casas correcionais, como “agências de repressão a indivíduos que infringiram ou se desviaram das normas ou valores socialmente estabelecidos e legitimados e a indivíduos perturbadores da ordem pública e familiar.” (MOREIRA, 1983: 66). Desse grupo de pessoas fazem parte os “alcoólatras, desordeiros e meninas perdidas” (MOREIRA, 1983: 68), os quais eram levados ao hospital, sendo punidas por desrespeito à moralidade vigente. 
A Psiquiatria, dessa forma, trabalhava juntamente com outras agências de controle e repressão social, como a organização penal, a polícia e a família, sendo responsável por definir os parâmetros de normalidade e estabelecer quem seria excluído desse padrão e qual seria seu tratamento. Seu status de ciência médica, porém, disfarçava o caráter repressor de suas ações. (MOREIRA, 1983).

A importância da Psiquiatria foi crescendo na medida em que foram incorporados ao seu campo de ação a avaliação e tratamento das pessoas consideradas normais em todas as esferas da vida social. Ela ultrapassou os muros da instituição psiquiátrica para oferecer tratamento a todos os tipos de pessoas, através do processo de medicalização das relações sociais, tornando os problemas do convívio social uma questão técnica.

Moreira (1983), afirma que, nessa perspectiva:

[...] a Psiquiatria torna-se o fulcro por excelência de um sistema político, e por isso ela não foi abandonada, enquanto instrumento de poder, nos regimes políticos mais variados. Afinal, ainda não se descobriu recurso melhor para promover a coesão social do que através da descoberta de bodes expiatórios, enquanto a sociedade for incapaz de conviver com as diferenças. (MOREIRA, 1993: 194).

Essa afirmação confirma a utilização da instituição psiquiátrica como uma agência de repressão e controle social, retirando do convívio da sociedade as pessoas que fogem às regras sociais, sob a lógica do tratamento.

\subsection{3- Relações de poder na instituição psiquiátrica}

Várias instituições sociais determinam sua atuação através da "nítida divisão entre quem tem o poder e quem não tem", estabelecendo níveis de hierarquia inflexíveis, que reproduzem a violência e a exclusão . (BASAGLIA, 1985: 101).

Basaglia (1985) afirma que:

Família, escola, fábrica, universidade, hospital: instituições que repousam sobre uma nítida divisão de funções, através da divisão do trabalho (servo e senhor, professor e aluno, empregador e empregado, médico e doente, organizador e organizado) [...]. De onde se pode ainda deduzir que a subdivisão das funções traduz uma relação de opressão e de violência entre poder e não-poder, que se transforma em exclusão do segundo pelo primeiro. (BASAGLIA, 1985: 101). 
A instituição psiquiátrica estabeleceu-se como uma dessas instituições onde a violência é justificada pela necessidade de controlar os efeitos da doença. (BASAGLIA, 1985).

O transtorno mental, historicamente, foi definido em contraponto à idéia de saúde mental, comparando comportamentos estranhos à sociedade com aqueles considerados normais. Cooper (1967) explicita essa relação de forma clara:

\begin{abstract}
Precisamos olhar para o Sadio Mental um pouco mais de perto. Desistimos da conotação, e vemos que, denotativamente, incluem-se nesse conceito as famílias dos pacientes, empregadores em exercício, clínicos gerais, funcionários do bem-estar mental, a polícia, magistrados, assistentes sociais, psiquiatras, enfermeiros de doenças mentais e muitos outros. Todas essas pessoas, algumas das quais podem ser muito sinceras e dedicadas ao paciente, estão inexoravelmente, se bem que a despeito de si mesmas, numa violência sutil contra o objeto de seus cuidados. (COOPER, 1967: 35).
\end{abstract}

Na perspectiva de David Cooper, por mais que os profissionais da saúde mental estabelecessem uma prática de cuidados com os pacientes, ultrapassando inclusive os limites institucionais para fornecer um bom serviço aos mesmos, "devemos lembrar também que as boas intenções e todas as pompas da respeitabilidade profissional muito frequentemente encobrem uma realidade humana verdadeiramente cruel.” (COOPER, 1967: 35).

Cooper (1967) afirma que no hospital psiquiátrico se reproduzem relações semelhantes àquelas produzidas na família do paciente, onde os profissionais assumem os papéis familiares numa relação interpessoal com o mesmo, criando o ambiente de submissão semelhante àquele em que o paciente não conseguiu adaptar-se em casa. Nesse contexto, afirma que à pessoa com transtorno mental restam poucas alternativas:

[...] pode decidir vegetar seus dias afora, numa enfermaria de doentes mentais crônicos, ou oscilar entre seu inferno familial e o não diferente inferno da enfermaria convencional de admissão psiquiátrica, constituindo a última, naturalmente, a idéia comum atual de progresso psiquiátrico. (COOPER, 1976: 38).

Além dessas representações da instituição psiquiátrica, várias práticas são determinadas tendo em vista as relações entre os profissionais, e também aquelas estabelecidas entre estes e os pacientes, durante seu período de internação. 


\subsubsection{1- Níveis de hierarquia ente profissionais}

Dentro dos hospitais, em geral, observa-se a soberania do saber médico em relação às outras áreas, como Enfermagem, Psicologia, Serviço Social e outras; existe uma verticalidade hierárquica com relação aos médicos e demais profissionais. Essa relação explicita uma luta de forças muito mais política que em nível de conhecimento; como afirma Teixeira (1993), “o fato de a instituição pertencer à máquina estatal propicia predominância da lógica política sob a da lógica técnica.” (TEIXEIRA, 1993: $63)$.

Nos hospitais psiquiátricos brasileiros, em particular, essa relação se torna bem mais interessante no que diz respeito à hierarquia médico - enfermeiro, pois essa última profissão surgiu no âmbito dessa instituição. Teixeira (1993) descreve o trajeto da Enfermagem no Brasil tendo início no Hospital Nacional dos Alienados, no Rio de Janeiro, por volta de 1980, afirmando que essa profissão surgiu pela necessidade de substituir as irmãs de caridade da Santa Casa de Misericórdia, à qual o hospital ainda estava subordinado nessa época.

Vianey (2005) coloca que a enfermagem surgiu no Brasil com o objetivo de organizar o hospício, de forma a disciplinar os pacientes através de uma prática medicamentosa, além de desenvolver atividades administrativas burocráticas.

Somente com o início da Reforma Psiquiátrica é que o paradigma da Enfermagem na instituição psiquiátrica passou da submissão conservadora aos médicos, para a compreensão do seu papel terapêutico e humanizado do cuidado com o paciente. Este processo se deu a partir do aprimoramento das técnicas de Enfermagem empregadas no âmbito hospitalar, engendrando a construção de teorias próprias para essa área de atuação, delimitando seu espaço profissional. (VIANEY, 2003).

Em relação às outras áreas, apesar das diversas tentativas atuais de interdisciplinaridade dentro da saúde após o advento da Reforma Psiquiátrica e do crescimento expressivo do trabalho de assistentes sociais, psicólogos e outros profissionais, o saber médico ainda se estabelece como superior aos outros, representando a peça-chave do hospital.

Esse quadro tem sido alterado à medida que os serviços alternativos à pratica manicomial, em sua maioria, são criados por e para equipes interdisciplinares, 
obrigando o saber médico a reconhecer a importância do trabalho de outros profissionais e desenvolver sua atuação em conjunto com as outras áreas da saúde.

\subsubsection{2- Relação profissionais - pacientes}

Outra característica importante de estudo na instituição psiquiátrica é a “centralidade das relações interpessoais de seus membros com a clientela. É, então, no processo de interação social que a equipe intervirá nas condutas do paciente e, ao mesmo tempo, lhe servirá de modelo normativo.” (MOREIRA, 1983: 36).

Uma particularidade da instituição psiquiátrica é que, diferente do que ocorre com as doenças clínicas em que a própria pessoa reconhece sua enfermidade e procura o serviço de saúde, na maioria dos casos de transtorno mental, esse é identificado pelos familiares e pessoas próximas ao paciente, o qual é encaminhado ao hospital psiquiátrico, muitas vezes, sem reconhecer-se doente. Dessa forma, geralmente essas pessoas são internadas de forma compulsória e sob a pressão dos familiares e da possibilidade de sofrer punições por parte dos profissionais. De acordo com Moreira (1983), essa posição “reforça o verticalismo das decisões e justifica a expropriação de qualquer nível de autonomia ou poder para a clientela.” (MOREIRA, 1983: 38).

A relação que se estabelecia no modelo manicomial entre o paciente e os profissionais do hospital, era marcada pela impessoalidade, pelo tratamento da doença, e não da pessoa. Principalmente entre o médico e o paciente, a relação era assimétrica, uma vez que, para o primeiro, todo discurso do paciente se tornava passível de análise, objeto de estudo; ou seja, as expressões, reivindicações e vontades do paciente deveriam ser examinadas, mas não ouvidas. (MOREIRA, 1983).

Em relação aos outros profissionais, no modelo manicomial, pouca credibilidade também se dava ao que era falado, "uma vez que a doença já teria deteriorado sua mente, e sua linguagem estaria, portanto, comprometida.” (MOREIRA, 1983: 121). Dentro do hospital psiquiátrico era reproduzida uma relação de subordinação e dependência, como explicita o fato de os objetos pessoais de todos serem entregues às enfermeiras. (MOREIRA, 1983).

Basaglia (1985) apresenta um quadro de exploração e desvalorização do paciente pelos profissionais, a partir de sua experiência de trabalho no hospital psiquiátrico, onde presenciou a ação de enfermeiros noturnos; esses, para marcarem o 
ponto durante a madrugada ${ }^{4}$, misturavam fumo com migalhas de pão e davam para um dos pacientes separar durante 30 minutos. Quando esse terminava o serviço, deveria acordar o enfermeiro e, assim, poderia ficar com o fumo. (BASAGLIA, 1985).

Os atendentes também imprimiam em suas práticas certa distância social dos pacientes, enfatizando as diferenças entre eles pelo tom de voz, as roupas e o tratamento pessoal; essa diferenciação pode ser interpretada pelo medo de se contaminarem com a patologia, pelo convívio diário com os pacientes diariamente. Como afirma Moreira (1983):

Apesar de a loucura ser percebida como basicamente orgânica, a constatação de que um paciente agitado leva à balbúrdia toda a ala faz pensar no caráter contagiante dela. É preciso, então, manter a desrazão quando muito nos pátios, para que ela não atinja as salas de enfermagem. (MOREIRA, 198: 122).

Essas relações têm se alterado na medida em que o novo modelo de atenção à saúde mental desenvolve-se nas instituições psiquiátricas. Basaglia (1985), entretanto, mostra que apenas a alteração do modelo não é suficiente para romper com a lógica manicomial, mas depende também do caráter das ações dos profissionais:

O novo psiquiatra social, o psicoterapeuta, o assistente social, o psicólogo da indústria, o sociólogo de empresa (para citar só alguns), são os novos administradores da violência no poder, na medida em que, atenuando os atritos, dobrando as resistências, resolvendo os conflitos provocados por suas instituições, limitam-se a consentir, com sua ação técnica aparentemente reparadora e não-violenta, que se perpetue a violência global. Sua tarefa, que é definida como terapêutico-orientadora, é adaptar os indivíduos à aceitação de sua condição, de "objetos de violência”, dando por acabado que a única realidade que lhes cabe é serem objeto de violência se rejeitarem todas as modalidades de adaptação que lhe são oferecidas. (BASAGLIA, 1985: 102).

A importância da ação dos profissionais nesse processo é confirmada por Serrano (1992), quando afirma que "a Psiquiatria alternativa não depende só de leis. Principalmente ela depende da disposição de seus profissionais e do elevado grau de participação do povo nas discussões, na fiscalização e nos projetos.” (SERRANO, 1992: 88).

\footnotetext{
${ }^{4}$ De acordo com Basaglia (1985), o enfermeiro noturno deveria marcar o ponto a cada trinta minutos, para provar que não estava dormindo.
} 


\section{2- Modelo psicossocial de atenção à saúde mental}

O modelo manicomial começou a ser criticado a partir da segunda metade do século XX, quando a descoberta dos medicamentos psicotrópicos possibilitou um grande alívio dos sintomas psiquiátricos. Ao mesmo tempo, novas teorias foram sendo formuladas e o transtorno mental passou a ser considerado tendo em vista o contexto social de seu portador, possibilitando a atuação de profissionais de outras áreas do saber, como psicólogos, assistentes sociais, músicos, artistas e outros; esses passaram a estudar o indivíduo e seu sofrimento em detrimento das condições de vida às quais está submetido. (MACHADO, 2006).

Assim, o paradigma biomédico, o qual tinha uma perspectiva individualista quanto à doença e ao sofrimento, foi superado pelo paradigma das Ciências Sociais, chamado, na saúde mental, de paradigma psicossocial, o qual considera a saúde, a doença e a cura como construções sociais a partir da tradução subjetiva da doença, com as suas ramificações pessoais, familiares, sociais e culturais. (GONÇALVES, 2004)

Além disso, o novo paradigma da saúde mental estabelece as pessoas com transtorno mental como sujeitos ativos no processo de tratamento e mudança do seu contexto social. A atenção psicossocial deve promover a saúde mental inclusive nos casos de doenças graves, a partir de alternativas de atendimento que supram essas demandas. (FAGUNDES, 1992).

A abordagem interdisciplinar impressa nos novos moldes de atenção à saúde mental passou a privilegiar a manutenção do convívio familiar e social como objetivo dos serviços terapêuticos, desconstruindo o manicômio e a institucionalização do indivíduo como única forma de atenção psiquiátrica.

O modelo psicossocial busca promover a inclusão da pessoa com transtorno mental à sociedade a partir da extensão da garantia dos direitos fundamentais dessa como cidadã, a participação da família no tratamento do paciente de forma efetiva, e a construção de serviços substitutivos ao manicômio na comunidade, desvinculados da lógica de internação compulsória e permanente. (MACHADO, 2006).

A lógica desse novo tipo de instituição baseia-se em proteger a pessoa com transtorno mental e conferir-lhe atenção integral para o restabelecimento de sua saúde mental, rompendo com a perspectiva de enclausurar os loucos para proteger a sociedade contra os riscos que esses poderiam representar. 
Machado (2006) afirma que “o novo paradigma reconhece que a instituição asilar nega a subjetividade dos sujeitos, nega todas as suas dimensões que não residem no corpo e, por isso mesmo, ele, homem, passa de sujeito à coisa.” (MACHADO, 2006: 17).

Diante disso, o paradigma psicossocial propõe a extinção do manicômio como espaço de tratamento para o louco; mas não apenas isso: propõe a extinção da lógica de exclusão e a construção de um novo olhar da sociedade sobre a loucura, sendo possível a expressão das diferenças em todos os aspectos da vida social, valorizando a pessoa com transtorno mental, garantindo à mesma um tratamento humanitário e de proteção à sua complexidade.

\section{3- Reforma Psiquiátrica internacional: antipsiquiatria e a desinstitucionalização}

As reflexões geradas sobre as relações humanas após a Segunda Guerra Mundial colocaram em evidência socialmente temas como a defesa de direitos sociais, culminando com a criação da Declaração Universal dos Direitos Humanos, em 10 de dezembro de 1948. (MACHADO, 2006). Nesse contexto, passou a ser criticada por profissionais da área psiquiátrica a representação social da loucura e a forma de tratamento empregado à mesma.

As primeiras propostas de Reforma Psiquiátrica, desenvolvidas na Inglaterra e nos Estados Unidos, limitavam-se, entretanto, a reestruturar as práticas psiquiátricas dentro do manicômio, buscando apenas melhorar as condições de vida dos pacientes nas instituições. Nestes países, foram estabelecidas comunidades terapêuticas, tendo em vista democratizar as relações dentro das instituições psiquiátricas, mas sem a perspectiva de romper com a lógica manicomial. (MACHADO, 2006).

Nos anos 1960 psiquiatras ingleses formaram um movimento chamado antipsiquiatria, o qual, diferentemente das propostas citadas acima, propôs a extinção do hospício como local de tratamento psiquiátrico, questionando o saber médico focalizado na doença e estabelecendo um "diálogo entre a razão e a loucura, entendendo que a loucura está entre os homens e não dentro deles”. (MACHADO, 2006: 22). 
A antipsiquiatria visava a reforma do modelo manicomial e a reconstrução da relação médico-paciente, valorizando seu discurso, passando-se a perceber a loucura como um fato social, fugindo ao reducionismo biologicista, e considerando a família como categoria central nessa discussão. (AMARAL, 2006).

Uma pessoa importante nesse processo foi David Cooper, médico psiquiatra inglês, que, junto com outros médicos, formou em 1975 a Rede Alternativa à Psiquiatria, que defendia a proteção dos loucos contra a violência da instituição e a organização de grupos de discussão para uma democracia participativa. Para Cooper (1967):

[...] a mais chocante forma de violência em Psiquiatria é nada mais do que a violência da Psiquiatria, na medida em que esta disciplina escolhe refratar e condensar sobre os pacientes que ela identifica a violência sutil da sociedade e que, com demasiada freqüência, representa para e contra esses pacientes. (COOPER, 1967: 13).

Cooper iniciou uma experiência em antipsiquiatria em 1962, quando colocou em funcionamento uma enfermaria em um hospital na Inglaterra que desenvolvia um trabalho distinto do tradicional. Ele identificou três necessidades para a construção de um novo modelo de atenção à saúde mental: a) separar os pacientes crônicos daqueles que estavam nas primeiras crises, muitas vezes jovens, estabelecendo para estes um local onde pudessem encontrar-se consigo mesmos; b) construir um local de trabalho no qual fosse possível estabelecer uma pesquisa sobre a interação dos pacientes com as famílias e em grupos terapêuticos; e, c) estabelecer um espaço fora da instituição psiquiátrica, como casas na comunidade, que permitissem uma "maior liberdade de movimentos, fora dos papéis altamente artificiais de funcionários e pacientes, impostos pela Psiquiatria convencional.” (COOPER, 1967: 111).

Os grupos terapêuticos funcionavam dentro da enfermaria, com o objetivo de registrar queixas de pacientes e funcionários de problemas ocorridos no cotidiano e construir projetos de Terapia Ocupacional, havia também grupos específicos direcionados aos funcionários para que os mesmos pudessem avaliar sua atuação e os resultados do tratamento. (COOPER, 1967).

Além da antipsiquiatria inglesa, outro movimento foi muito importante para a construção de um novo modelo de atenção à saúde mental, o qual foi a Reforma Psiquiátrica italiana preconizada por Franco Basaglia, sob os princípios da desinstitucionalização. 
Franco Basaglia foi o diretor do Hospital de Gorizia, no nordeste italiano, onde nasceu uma associação chamada Psiquiatria Democrática, a qual propunha transformar o hospital em uma comunidade democrática humanizada. (SERRANO, 1992). Na prática, a equipe médica estabeleceu uma sociedade dentro do hospital, com a criação de grupos de discussão sobre as condições desse e do tratamento oferecido, nos quais os pacientes tinham voz ativa. Basaglia começou a perceber que a passividade e a agressividade de muitos pacientes não eram apenas resultado do transtorno, como o regime manicomial dizia, mas sim a expressão de tantos anos de internação numa instituição opressora. (SERRANO, 1992).

Como conta Basaglia (1985) em sua experiência:

\begin{abstract}
A situação que encontramos em nossa instituição apresentava-se altamente institucionalizada em todos os seus setores: doentes, enfermeiros, médicos [...]. Tratou-se então de provocar uma situação de ruptura capaz de descristalizar as funções dos três pólos da vida hospitalar, dispondo-os em um jogo de tensões e de contenções em que todos estivessem envolvidos e por que todos fossem responsáveis. Isso implicava em um "risco", mas era o único meio de equiparar em um mesmo nível médicos e doentes, doentes e equipe do hospital, todos unidos em torno da mesma causa, unidos em direção a um objetivo comum. (BASAGLIA, 1985: 115).
\end{abstract}

Em contraste com o modelo manicomial, "na situação comunitária, o médico é quotidianamente contestado e controlado por um paciente que já não se pode afastar ou ignorar.” (BASAGLIA, 1985: 119).

Dessa forma, além de transformar as relações dentro do hospital, era preciso tirar de dentro dos pacientes a instituição psiquiátrica, de forma que os mesmos pudessem reconhecer-se como sujeitos autônomos; e também, reconhecer o saber médico como insuficiente para responder à questão da loucura em sua integralidade. (MACHADO, 2006). Surgiu, então, a idéia da desinstitucionalização.

De acordo com Rotelli, Leonardis e Mauri (1990), o processo de desinstitucionalização não remete simplesmente à desospitalização - em tirar os pacientes dos hospitais psiquiátricos - mas vai mais além, começando pelo desmonte da relação problema-solução, renunciando a perseguir a solução racional da Psiquiatria, a qual visa à normalidade plenamente restabelecida. A proposta desse processo é de transformar o sofrimento, garantindo plenas condições de cidadania e vida social aos portadores de transtorno mental. É a reconstrução da complexidade do objeto doença; a ênfase não é mais colocada no processo de cura, mas no projeto de invenção da saúde e de reprodução social do paciente. 
Foi nessa perspectiva que Franco Basaglia iniciou na cidade de Trieste, em 1971, uma proposta de atendimento psiquiátrico que realmente rompeu com a lógica manicomial. Como colocam Amarante e Rotelli (1992):

Aí começa a verdadeira demolição do aparato manicomial com a extinção dos "tratamentos" violentos, a abertura dos cadeados e das grades, a destruição dos muros que separavam o espaço interno do externo, a constituição de novos espaços e formas de lidar com a loucura e a doença mental. (AMARANTE; ROTELLI, 1992: 43).

Amarante e Rotelli (1992) deixam claro que essa desconstrução não representou o fim do tratamento psiquiátrico; o novo modelo proposto por Basaglia não somente preconizava o fechamento dos hospitais psiquiátricos, mas entendia a necessidade de cuidar das pessoas com transtorno mental sob uma nova perspectiva, construindo outras possibilidades de atendimento que garantissem condições de cidadania. Nas palavras de Amarante e Rotelli (1992):

[...] a “negação da instituição" não é a negação da doença mental, nem a negação da Psiquiatria, tampouco o simples fechamento do hospital psiquiátrico, mas uma coisa muito mais complexa, que diz respeito fundamentalmente à negação do mandato que as instituições da sociedade delegam à Psiquiatria para isolar, exorcizar, negar e anular os sujeitos à margem da normalidade social. (AMARANTE; ROTELLI, 1992: 44).

Quando do fechamento da instituição manicomial por Basaglia foram sendo construídos, com a perspectiva de promover um novo atendimento em saúde mental, serviços que substituíam o antigo hospício. Dessa forma, foram criados sete centros de saúde mental espalhados pela cidade de Trieste, os quais, com pouco tempo de funcionamento, passaram a atender 24 horas por dia as demandas psiquiátricas. Além disso, foram criados grupos-apartamentos para moradia de alguns usuários, acompanhados ou não de técnicos da saúde. Outra iniciativa importante para a descontrução do manicômio foi a criação de cooperativas de trabalho, as quais surgiram com a necessidade de empregar os pacientes que saíram do hospital mas não encontravam trabalho na sociedade; além dessa função, essas cooperativas “representam um novo espaço de produção artística, intelectual ou de prestação de serviços que assumem um importante papel na dinâmica e na economia não apenas dos serviços de saúde mental, mas também de toda a cidade.” (AMARANTE; ROTELLI, 1992: 44).

Todas essas propostas mostram como esse novo modelo instalado por Basaglia girava em torno da desconstrução do manicômio como espaço próprio de tratamento e 
vida das pessoas com transtorno mental, quebrando o antigo paradigma de que o paciente se tornava parte da instituição, estando confinado a ela. Baseando-se na idéia da desinstitucionalização é que os serviços substitutivos vão sendo implementados dentro e fora das instituições psiquiátricas.

Rotelli, Leonardis e Mauri (1990) explicam que a desinstitucionalização visa mobilizar todos os atores envolvidos no sistema de ação institucional. Os técnicos da saúde mental devem ativar toda a rede de relações que estruturam esse sistema e dinamizar as competências, os poderes, os interesses e as demandas sociais; as relações de poder entre instituições e sujeitos são transformadas através de gestos elementares, em que os direitos civis dos pacientes são protegidos, eliminando a coação, as tutelas jurídicas e os meios de contenção, reconstruindo o direito e a capacidade de palavra, produzindo relações e espaços de interlocução; enfim, garantindo uma existência mais rica de recursos, possibilidades e experiências.

Dessa forma, esse processo representa um trabalho complexo para os técnicos e administradores, mas permite uma participação essencial da comunidade e, potencialmente, uma enorme mobilização de energias, constituindo o oposto de toda prática de abandono desenvolvida pelo modelo manicomial. (ROTELLI, LEONARDIS; MAURI, 1990).

Isso mostra a importância da atuação dos profissionais da saúde mental não apenas na execução dos serviços oferecidos à população, mas também no engajamento político necessário à uma reformulação cultural e social da loucura e da sua própria atuação profissional. Como o modelo de desinstitucionalização italiano inspirou a Reforma Psiquiátrica brasileira, essa relação com os profissionais se fez de forma marcante, provocando grandes movimentações sociais, num contexto político propicio à reestruturação dos serviços de saúde e de garantia de direitos sociais. 


\section{Capítulo 2}

\section{Construção da Reforma Psiquiátrica no Brasil e no DF}

A Reforma Psiquiátrica no Brasil iniciou-se no contexto das lutas pela redemocratização política e de transformações significativas no modelo de atenção à saúde de forma geral. Foi construída, inicialmente, por movimentos de trabalhadores, usuários dos serviços de saúde mental e entidades civis, além de ter sido normatizada por meio de leis específicas para essa área.

Para entender como se deu o processo da Reforma no Brasil e, posteriormente, no Distrito Federal (DF), é necessário conhecer a instituição psiquiátrica brasileira antes do seu advento. Esse contexto torna possível analisar as mudanças proporcionadas pela Reforma, a partir da compreensão dos paradigmas que foram quebrados, a ideologia dos movimentos que emergiram, e a transformação nos serviços oferecidos.

\section{1- Saúde mental no Brasil antes da reforma}

Nos livros de história, onde fala-se sobre o início da colonização brasileira, a figura do louco não aparece de forma específica, nem o trato que lhe era atribuído pela sociedade da época. Considerando a tendência histórica universal, supõe-se, então, que os loucos sem vínculos familiares que não tinham atitudes de agressividade perambulavam pelas ruas sem sofrer repressão social, vivendo da caridade das famílias. Aqueles que tinham comportamento violento eram colocados nas prisões. No entanto, a grande maioria das pessoas com transtorno mental era escondida por suas famílias em quartos fechados ou cômodos separados do conjunto da casa, por vezes amarrados, para conter os comportamentos agressivos. (RESENDE, 1987).

De acordo com COSTA (1976), até a segunda metade do século XIX, as pessoas com transtorno mental que habitavam o Rio de Janeiro (capital do Brasil na época) não eram alvo de nenhuma assistência médica específica. Os mesmos eram encarcerados nas prisões, acusados de vagabundagem ou perturbação da ordem pública, ou então eram colocados em celas especiais dos hospitais gerais da Santa Casa de Misericórdia, as quais, em geral, eram insalubres, onde sofriam castigos corporais.

Como afirma Resende (1987): 
As Santas Casas de Misericórdia incluem-nos entre seus hóspedes, mas dálhes tratamento diferenciado dos demais, amontoando-os em porões, sem assistência médica, entregues a guardas e carcereiros, seus delírios e agitações reprimidos por espancamentos ou contenção em troncos, condenando-os literalmente à morte por maus tratos físicos, desnutrição e doenças infecciosas. (RESENDE, 1987: 35).

A partir de 1830, médicos higienistas sugeriram a criação de hospícios de caráter asilar, para que os loucos pudessem ser colocados em um ambiente limpo, arejado, e recebessem tratamento moral e medicamentoso. No entanto, o principal objetivo dessa medida era tirar das ruas as pessoas com transtorno mental que haviam sido abandonadas, mantendo assim a higiene pública. (COSTA, 1976).

O marco inicial da assistência psiquiátrica brasileira foi a inauguração do Hospício D. Pedro II, em 1852, o qual tinha capacidade para receber 350 pessoas, lotação que, em um ano, já estava alcançada, pois destinava-se a atender todo o Império. Era localizado na Praia Vermelha, um bairro, na época, isolado da cidade do Rio de Janeiro. Permaneceu sob a direção das Santas Casas de Misericórdia, as quais também ofereceram seus porões em outras cidades para a abertura de novos hospícios. (RESENDE, 1987).

No início do funcionamento dessas instituições, os médicos estavam praticamente excluídos do tratamento, uma vez que a direção ainda estava nas mãos das Irmãs de Caridade das Santas Casas. Dessa forma, aqueles apenas visitavam os hospitais em caso de alguma doença clínica. (RESENDE, 1987). Apenas em 1881 um médico generalista assume a direção do hospital. (COSTA, 1976).

O Hospício D. Pedro II só foi subordinado ao Estado em 1890, após a instauração da República, quando passou a se chamar Hospital Nacional dos Alienados. A partir do Governo Campo Sales (entre 1898 e 1902), os recursos para a assistência psiquiátrica foram sendo restringidos, fazendo que o Hospital Nacional dos Alienados se tornasse apenas uma casa de detenção para as pessoas com transtorno mental. (COSTA, 1976).

Assim, a ideologia das primeiras instituições psiquiátricas no Brasil permeou entre três funções: a) proteger a sociedade dos riscos que os loucos poderiam representar, excluindo-os do convívio familiar e recolhendo-os às instituições; b) curar a doença que lhes acometia, internando-os por indicação clínica; e, c) diminuir seu sofrimento tanto pela doença, quanto pela sociedade, sob a perspectiva caritativa da época. (RESENDE, 1987). 
No entanto, as funções de exclusão e recolhimento dessas pessoas às instituições sobressaíram às outras funções esboçadas, como coloca Resende (1987):
A função exclusivamente segregadora do hospital psiquiátrico nos seus primeiros quarenta anos de existência aparece, pois, na prática, sem véus ou disfarces de qualquer natureza. (RESENDE, 1987: 39).

Apenas em 1912 é que a Psiquiatria se tornou uma especialidade médica no Brasil; a partir de então, vários estabelecimentos para pessoas com transtorno mental foram criados. No entanto, somente em 1934 é que as instituições e a prática da Psiquiatria no Brasil foram regulamentadas, por meio do decreto $\mathrm{n}^{\circ} 24.559 / 34$, o qual dispunha "sobre a assistência e proteção à pessoa e aos bens dos psicopatas" 5 . Esse decreto representou a principal medida do Governo Vargas sobre este tema. (AMARAL, 2006). Nessa época, a doença mental era tratada como caso de polícia, em que o tratamento visava proteger a sociedade contra a periculosidade do "psicopata ou

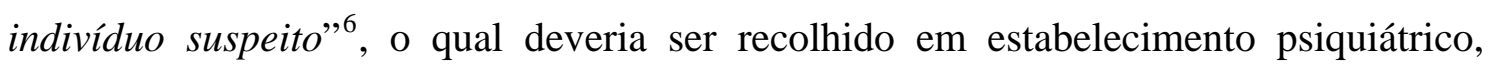
sendo considerados "absoluta ou relativamente incapazes de exercer pessoalmente os atos da vida civil"7

A partir desse decreto a Psiquiatria alcançou uma maior importância social, sendo reconhecida juridicamente e recebendo investimento para pesquisa e formação específica na área; mas a falta de delimitação do campo de estudo e atuação da Psiquiatria não permitiram uma mudança cultural em torno da visão sobre o transtorno mental. (AMARAL, 2006).

Dessa forma, a grande maioria dos loucos recolhidos pelo governo ainda era confinada nas prisões, dividindo o espaço e os maus tratos sofridos pelos bêbados, criminosos e condenados. A perspectiva dessas casas correcionais era reeducar os perturbadores da ordem social através do trabalho; e os loucos eram submetidos às mesmas condições que os demais. (RESENDE, 1987).

Resende (1987) reconhecia uma característica da Psiquiatria, que se perpetuou por longos anos:

Exclusão, eis aí, numa só palavra, a tendência central da assistência psiquiátrica brasileira, desde seus primórdios até os dias de hoje, o grande e sólido tronco de uma árvore que, se deu e perdeu ramos ao longo de sua vida

\footnotetext{
${ }^{5}$ Decreto ${ }^{\circ} 24.559 / 34$.

${ }^{6}$ Decreto n ${ }^{\circ} 24.559 / 34$. Art. 10

${ }^{7}$ Decreto ${ }^{0}$ 24.559/34. Art. 26
} 
e ao sabor das imposições dos diversos momentos históricos, jamais fletiu ao ataque de seus contestadores e reformadores. (RESENDE, 1987: 36).

Nessa época, a intervenção era baseada no biologismo ${ }^{8}$, que entende os problemas psiquiátricos como resultantes de causas biológicas; considerando-as suficientes para explicar tanto os problemas psíquicos, como o funcionamento cultural da sociedade. (COSTA, 1976).

Foi nessa perspectiva que fundou-se, em 1923, a Liga Brasileira de Higiene Mental (LBHM), pelo psiquiatra Gustavo Riedel, como o objetivo de melhorar as condições do atendimento às pessoas com transtorno mental através de uma renovação dos profissionais e dos estabelecimentos de Psiquiatria. Esta era uma entidade civil, mantida por filantropos e subvenção federal, que representava a elite psiquiátrica do Rio de Janeiro. (COSTA, 1976).

A LBHM fez do pensamento biologisante da Psiquiatria da época uma ideologia conivente com os preconceitos sociais em torno da loucura. Nos seus programas de higiene mental, os psiquiatras dessa instituição incluíram o ideal de eugenia ${ }^{9}$. Este já vigorava antes da criação dessa instituição, reproduzido pela elite intelectual da época, que atribuía os problemas econômicos e sociais do regime republicano do Brasil à sua formação social. De acordo com Costa (1976), para esses intelectuais:

O brasileiro não tinha podido promover o desenvolvimento harmônico do
país porque o calor e a mistura com "raças inferiores" tinham-no tornado
preguiçoso, ocioso, indisciplinado e pouco inteligente. Infelizmente nada
podia ser feito contra o clima. Em contrapartida, o problema racial ainda
podia ser resolvido. (COSTA, 1976: 36).

Foi essa ideologia que os psiquiatras carregaram para os programas de higiene mental, legitimando os preconceitos sociais em torno da loucura:

[...] a História da Psiquiatria brasileira criou uma atmosfera psiquiátrica saturada de conotações ideológicas. A L.B.H.M. herdou esse tipo de pensamento, reforçando-o e desenvolvendo-o, graças à incapacidade que tiveram seus psiquiatras em discriminar aquilo que nas suas teorias era determinado pelos preconceitos da cultura. (COSTA, 1976: 37).

\footnotetext{
${ }^{8}$ De acordo com o sítio da Associação Paulista de Medicina de Família e Comunidade, “o biologismo pressupõe o reconhecimento predominante da natureza biológica das doenças, de suas causas $e$ conseqüências".

${ }^{9} \mathrm{O}$ termo eugenia, ou boa geração, foi cunhado por Francis Galton em 1883, no livro Inquires into human faculty. Sob a influência da leitura do livro de seu primo Charles Darwin, A origem das espécies, Galton lança as bases do que depois ganhará o nome de eugenia com o livro Hereditary genius (1869). Nesse livro, Galton procura demonstrar que a capacidade humana decorria da hereditariedade mais do que da própria educação. Segundo definição do próprio Galton, Eugenia é a "ciência que lida com todas as influências que melhoram as qualidades natas de uma raça; também aquelas que as desenvolvem à máxima vantagem "' (SILVA, 2004).
} 
Essa perspectiva foi impulsionada pela crescente aceitação da eugenia como campo de estudo e atuação nos meios políticos, ideológicos e médicos incentivando a sua propagação para todos os domínios da vida social, e não apenas para o psíquico. A idéia propagada pelos eugenistas ${ }^{10}$ era a da seleção natural dos indivíduos defendendo que a criação de instituições para mendigos, criminosos e loucos, eram medidas onerosas para o Estado e para a parte produtiva da sociedade, pois mantém a vida de homens inferiores, que a própria natureza deveria eliminar. (COSTA, 1976).

Dessa forma, a eugenia propunha a esterilização das pessoas com transtorno mental, de forma a propagação da loucura nos filhos. A Igreja Católica, porém, posicionou-se contrária a essa sugestão, em defesa da integridade corporal e da dignidade humana. (COSTA, 1976).

Foi essa herança do pensamento psiquiátrico que influenciou a prática de várias instituições psiquiátricas ao longo de muitos anos no Brasil.

O fim da escravidão e, progressivamente, a emergência do capitalismo comercial e industrial brasileiro, além do desenvolvimento do comércio em cidades como Rio de Janeiro e São Paulo, provocaram o aumento demográfico acelerado das cidades; consequentemente houve a proliferação de cortiços e favelas, onde as condições de saneamento, higiene, controle de doenças e epidemias eram precárias. Essa situação mostrou a insuficiência da prática religiosa para suprir todas as demandas decorrentes dos problemas sociais, impulsionando uma maior cientificidade na promoção da saúde geral e da saúde mental. (RESENDE, 1987).

Dessa forma, iniciou-se uma nova fase da Psiquiatria, em que esta se tornou parte da saúde pública, sob a execução do Estado. No entanto, a clientela do hospício ainda não diferia daquela que, primeiramente, ocupara o espaço da instituição psiquiátrica. (RESENDE, 1987).

No Brasil difundiu-se a prática laboral nos hospitais psiquiátricos, mais como uma adesão política que clínica a esse tipo de tratamento, considerando a ideologia da

\footnotetext{
${ }^{10}$ Médicos que adotavam a perspectiva da eugenia em suas práticas. Moura (2005) afirma que ainda nos dias atuais as idéias eugenistas estão presentes em algumas práticas médicas no Brasil, principalmente nos estudos de desenvolvimento genético, em que se pode evitar deficiências, características estéticas, deformações, entre outros aspectos na reprodução humana. Segundo a autora, a perspectiva de padronização e normatização humana ainda sobrepõe a ética da diversidade em alguns espectros da ciência. (MOURA, 2007).
} 
época em torno da cidadania, a qual tinha uma relação direta com a inserção em alguma profissão reconhecida. (RESENDE, 1987).

Essa iniciativa está relacionada ao modelo de atendimento da reforma italiana, no qual as cooperativas de trabalho representavam uma possibilidade de tratamento através da criação de espaços para a produção artística e cultural, além da reintegração dos loucos pela prestação de serviços à comunidade, garantindo a participação destes na reprodução material da sociedade. (AMARANTE; ROTELLI, 1992).

No entanto, a realidade fora dos asilos, nessa época, já estava longe das atividades desenvolvidas nas colônias, como afirma Resende (1987)

[...] a nova e dinâmica lavoura cafeeira exportadora paulista pedia braços, é certo, mas é duvidoso que o hospício pudesse lhe oferecer o material humano eficiente e disciplinado de que necessitava. (RESENDE, 1987: 51).

Dessa forma, as colônias perpetuaram a função histórica do hospital psiquiátrico de apenas retirar da sociedade aquelas pessoas que não eram desejadas por esta. A própria população das colônias demonstra essa função, como afirma Resende (1987):

\begin{abstract}
De fato, quem se dispuser a examinar a população das nossas colônias de alienados vai encontrar, amalgamadas à massa de crônicos, tornada indiferenciada pela cultura mesma do asilo, desde pessoas que lá chegaram após uma passagem por um hospital psiquiátrico até indivíduos em cuja história de vida consta, como determinante de internação, "doenças" como a de moças namoradeiras que foram desvirginadas e desonradas, crianças que se tornam órfãs, mendigos ou arruaceiros que, pela intermediação de um chefe de polícia local ou um delegado de polícia, encontraram no encaminhamento ao hospício a solução definitiva. (RESENDE, 1987: 52).
\end{abstract}

Até mesmo as práticas de maus tratos e torturas continuaram sendo reproduzidas nas colônias; essas ficaram superlotadas em todo o país, com péssimas condições de higiene, cuidados e moradia para os pacientes. (RESENDE, 1987).

Com o crescimento da indústria capitalista, os trabalhadores, para prevenirem-se contra os efeitos da exploração de sua mão-de-obra, criaram as Caixas de Aposentadoria e Pensão, que eram fundos de pensão restritos aos trabalhadores de cada empresa, com vistas a garantir alguns benefícios, como pensão em caso de morte, aposentadoria, auxílio-doença, entre outros. Mais tarde, esses fundos passaram a ser organizados por categoria profissional, por meio dos Institutos de Aposentadoria e Pensão, os quais, além de outros benefícios, garantiam assistência médica por meio dos sindicatos. O restante da população ficava a mercê das ações de promoção de saúde e prevenção de doenças pela vacinação, por exemplo, realizadas em caráter universal pelo Ministério da 
Saúde, o qual também se encarregava pela assistência médico-hospitalar para poucas doenças, oferecida aos indigentes e não segurados pela previdência.

Apenas na década de 50 é que a assistência psiquiátrica começou a ser incorporada ao conjunto das práticas previdenciárias. Porém, a precariedade dos hospitais públicos de saúde mental incentivou a contratação de leitos psiquiátricos em hospitais privados, os quais seriam destinados a receber as pessoas com transtorno mental seguradas ou dependentes. (RESENDE, 1987).

As condições nos hospitais psiquiátricos públicos eram terríveis: não se escapava dos eletrochoques, celas fortes, doses altíssimas de medicação; e os pacientes ficavam jogados nos pátios ou perambulando pelos corredores. Não tinham nenhuma perspectiva de futuro, projeto coletivo ou acesso a qualquer decisão. (LOBOSQUE, 2001). Estes hospitais encarregaram-se de atender à população indigente, a qual estava à margem da sociedade capitalista. Nos hospitais privados, contratados pela previdência para atender seus segurados, a função de abrigar e vestir o paciente passou a ser prioritária, em detrimento do tratamento psiquiátrico que deveria ser oferecido aos trabalhadores internados, tornando-se instituições asilares. (RESENDE, 1987).

Nas décadas de 60 e 70, houve um aumento significativo de leitos financiados pelo Governo em hospitais privados para atender aos segurados da previdência social, “caracterizando uma situação de comercialização da doença mental cuja intensidade não encontra paralelo em outros países.” (DELGADO, 1987: 173).

Esse processo proporcionou o aumento significativo do número de hospitais psiquiátricos privados nas décadas seguintes, vindo a cair apenas nos anos 90, a partir da implantação da Política de Saúde Mental no Brasil.

\section{2- Surgimento da reforma psiquiátrica no Brasil}

O modelo de atenção em saúde mental preconizado pela Reforma Psiquiátrica brasileira carrega muitos elementos das reformas internacionais, sendo, porém, consolidada tardiamente com relação a essas. No entanto, a emergência desses novos modelos, a insatisfação de várias categorias profissionais atuantes na saúde mental, o contexto de reabertura democrática e a luta social pela reestruturação da saúde em geral, forma elementos que incentivaram a articulação de movimentos sociais em favor de 
uma Reforma Psiquiátrica que não apenas melhorasse as condições dos hospitais, mas que construísse um novo modelo de atenção psiquiátrico.

Dessa forma, a implementação da Reforma Psiquiátrica no Brasil e, posteriormente, no Distrito Federal (DF) foi um processo de construção histórica, passando pela Reforma Sanitária e pela criação de vários movimentos sociais que criticaram o modelo manicomial, propondo novas alternativas de atendimento à saúde mental, até sua consolidação por meio de legislação específica.

\subsection{1- Reforma psiquiátrica no contexto da reforma sanitária}

Desde o início dos anos 70, a assistência médica no Brasil constituiu-se em torno de alguns aspectos: a cobertura médica aos segurados da previdência social era oferecida pelo Instituto Nacional de Assistência Médica da Previdência Social ${ }^{11}$ (INAMPS), o qual incorporou os serviços de saúde que anteriormente eram oferecidos pelos sindicatos, no âmbito dos Institutos de Aposentadoria e Pensão. Nessa época, a política de saúde direcionava a assistência para uma prática médica curativo-individual, deixando em segundo plano as ações da saúde coletiva; além disso, repercutia-se a utilização de serviços privados comprados pela previdência, incentivando a mercantilização da saúde. (TEIXEIRA; MENDONÇA, 1989).

O processo de redemocratização política iniciado no fim dos anos 70 evidenciou a dívida social gerada durante a ditadura militar, trazendo à tona a necessidade de criar políticas públicas que promovessem a equidade e a justiça social. Nesse contexto, as universidades tornaram-se espaço de resistência contra o autoritarismo do governo militar, ao mesmo tempo em que a Organização Panamericana de Saúde passou a recomendar a criação de Departamentos de Medicina Preventiva nas faculdades, os quais passaram a formar seus alunos a partir da compreensão dos determinantes sociais da doença, indo contra a perspectiva curativa da saúde previdenciária. (TEIXEIRA; MENDONÇA, 1989).

Dessa forma, formou-se, no âmbito das universidades, o Movimento Sanitário, o qual buscava a difusão de novas práticas políticas na área médica a partir de projetos de

\footnotetext{
${ }^{11}$ Instituto responsável pela assistência médica à população segurada pela Previdência Social; ou seja, só podiam ser atendidos nesses hospitais os trabalhadores com carteira assinada e seus dependentes.
} 
medicina comunitária. Esses projetos permitiram a construção de uma política alternativa para a saúde, investindo-se na saúde coletiva e garantindo uma atenção mais ampla aos não-segurados.

O Movimento Sanitário ganhou maior importância no início da década de 80, quando a Previdência Social começou a entrar em crise, inclusive em relação ao modelo privatizante de atendimento, e este movimento foi o único que apresentou um projeto concreto de reformulação da saúde. Foi então que a luta pela construção de um novo sistema de saúde entrou para a discussão da Previdência Social, responsável pelo atendimento médico da maior parte da população. (TEIXEIRA; MENDONÇA, 1989).

A partir de então, o Movimento Sanitário projetou suas ações em direção a politizar a questão da saúde através de conferências onde foi possível estabelecer um grande debate em torno da democratização do acesso e do direito à saúde como dever do Estado.

A participação do Movimento Sanitário e da população nas decisões sobre os rumos da saúde pública no Brasil se deu de forma efetiva na VIII Conferência Nacional de Saúde (CNS), que ocorreu em 1985, a qual marcou a história das conferências de saúde. Nesta conferência as reivindicações desse movimento foram consolidadas em propostas específicas para várias áreas da saúde, as quais fizeram parte da construção do texto da Constituição da República Federativa do Brasil de 1988 (CF/88). Essa definiu a saúde como um direito universal e dever do Estado, garantido através de um sistema único e descentralizado, o Sistema Único de Saúde (SUS). O SUS, estabelecido na $\mathrm{CF} / 88^{12}$, foi consolidado com as leis orgânicas da saúde: Lei $\mathrm{n}^{\circ} 8.080 / 90{ }^{13}$, e a Lei n. ${ }^{\circ}$

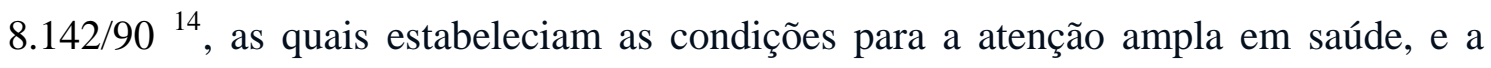
participação da comunidade na gestão do SUS, respectivamente.

Os princípios que norteiam as ações do SUS, estabelecidos pela Lei $\mathrm{n}^{\circ}$ 8.080/90, são: a) a universalidade de acesso como um direito social; b) a eqüidade no atendimento; c) a descentralização da gestão, com a participação dos estados e municípios; d) a garantia de atenção integral em todos os níveis de complexidade; e, e) a

\footnotetext{
${ }^{12} \mathrm{CF} / 88$. Arts. 196 a 200.

${ }^{13}$ Lei n ${ }^{\circ} 8.080$ de 19 de Setembro de 1990. "Dispõe sobre as condições para a promoção, proteção e recuperação da saúde, a organização e o funcionamento dos serviços correspondentes e dá outras providências".

${ }^{14}$ Lei n. ${ }^{\circ} 8.142$ de 28/12/1990. "Dispõe sobre a participação da comunidade na gestão do Sistema Único de Saúde - SUS - e sobre as transferências intergovernamentais de recursos financeiros na área da saúde e dá outras providências.”
} 
participação da comunidade na construção das políticas por meio dos conselhos de saúde.

Atualmente, nem todos esses princípios vêm sendo cumpridos na prática, pois esbarram em um problema crônico das políticas sociais: a escassez de recursos financeiros. No entanto, não se pode deixar de reconhecer os avanços alcançados para a saúde pública no Brasil a partir da instauração desse modelo.

\subsection{2- Movimentos pela construção do modelo antimanicomial}

Em meados de 1978, motivados pelo Movimento Sanitário, vários profissionais da saúde mental passaram a denunciar as condições precárias dos serviços públicos de Psiquiatria. Em meio às mobilizações sociais, surgiu a discussão entre Psiquiatria e democracia, além da reivindicação de psicólogos e médicos por melhores condições de trabalho e salários no âmbito da saúde mental.

Nessa época, psiquiatras do INAMPS começaram a questionar as precárias condições de vida da classe trabalhadora e o mau atendimento oferecido pela saúde previdenciária, associando-as com o aumento da demanda por tratamento psiquiátrico. Junto com outros profissionais da saúde mental, tais como psicólogos, assistentes sociais, enfermeiros, sociólogos e terapeutas ocupacionais, organizaram vários encontros para discutir a situação da assistência psiquiátrica no Brasil. (SERRANO, 1992).

No Rio de Janeiro, por exemplo, os trabalhadores da Divisão Nacional de Saúde Mental organizaram-se para denunciar a violência, a desassistência e a marginalização das instituições psiquiátricas, além de criticar a existência de uma indústria da loucura, criada pelo setor privado e pela política privatizante da previdência social a que era submetida a assistência para os trabalhadores segurados. (AMARANTE ; ROTELLI, 1992).

A partir dessas denúncias, formou-se o Movimento dos Trabalhadores em Saúde Mental (MTSM) o qual, junto com outras instituições e movimentos, passou a criticar o modelo manicomial de tratamento psiquiátrico, tendo em vista uma reformulação nas políticas de saúde mental até então implementadas. Esse movimento se contrapôs ao 
Governo Militar, denunciando práticas de tortura e violência no âmbito do tratamento psiquiátrico. (AMARAL, 2006).

O MTSM crescente em todo o país foi fortalecido com a visita de Franco Basaglia $^{15}$ ao Brasil, em junho e julho de 1979, por acontecimento do III Congresso Mineiro de Psiquiatria, realizado em Belo Horizonte; suas palestras foram um grande incentivo para os trabalhadores da saúde mental denunciarem a crueldade da instituição psiquiátrica. (SERRANO, 1992).

Este congresso foi um marco de discussão em torno da questão psiquiátrica, tendo como pano de fundo o contexto do Hospital-Colônia de Barbacena, cuja realidade equiparava-se, na visão de Franco Basaglia, a um campo de batalha. Foi nesse evento que se consolidou a necessidade de uma nova consciência dos profissionais em torno da situação da saúde mental no país, a partir das denúncias feitas no congresso de saúde mental em nível nacional, realizado em Santa Catarina no ano anterior, o qual tratou da questão da mercantilização do atendimento psiquiátrico e da situação precária dos hospitais públicos. (DELGADO, 1987).

Esse último congresso foi o impulsionador da realização do Primeiro Encontro Nacional de Trabalhadores em Saúde Mental, realizado em São Paulo, em 1979, onde as várias categorias profissionais atuantes nas instituições psiquiátricas discutiram o seu papel político para a transformação do modelo psiquiátrico vigente. Nessa época, foram questionadas as internações em leitos privados, tendo em vista o incentivo das instituições particulares em manter longas internações para a obtenção de maior lucro por parte dessas, além das condições de violência e abandono dos hospitais públicos. Embora caracterizados por condições diferentes, ambos os sistemas faziam perpetuar na Psiquiatria a lógica da segregação e exclusão social. (DELGADO, 1987).

Toda essa situação, de acordo com Delgado (1987), mostrou que:

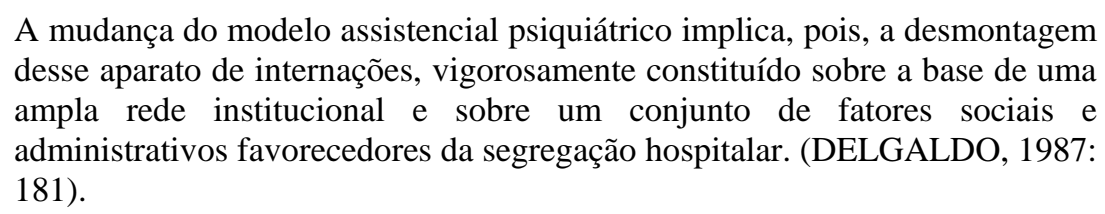

\footnotetext{
${ }^{15}$ Psiquiatra italiano que instituiu o modelo de desinstitucionalização no âmbito da saúde mental, grande responsável pela Reforma Psiquiátrica italiana.
} 
No entanto, esse movimento não conseguiu consolidar, até o fim dos anos 70, um modelo de Psiquiatria alternativa no Brasil, sendo esta apenas desenvolvida em algumas iniciativas dentro da estrutura psiquiátrica tradicional.

Tornou-se necessária, então, a construção de uma nova forma de compreender e praticar a atenção psiquiátrica no Brasil, que transformasse a base de atuação profissional, a perspectiva social em torno da loucura, a implementação dos serviços de saúde mental, e não apenas contornasse a situação caótica da atenção psiquiátrica da época. Cabia a essas discussões definir as estratégias de desospitalização dos pacientes psiquiátricos através de uma prática assistencial que não mais os isolassem da comunidade, mas que promovesse a reintegração social. (DELGADO, 1987).

Aproveitando o contexto da realização da VIII CNS, a qual foi muito importante para a consolidação das reivindicações do Movimento Sanitário sobre os princípios do SUS, foi realizada a I Conferência Nacional de Saúde Mental (CNSM), em julho de 1987. Nessa foi levantada a necessidade de integrar trabalhadores da saúde mental e sociedade civil para transformar as práticas institucionalizadas; além disso, enfatizouse a importância da participação popular para elaborar e executar a política de saúde mental, quebrando a barreira entre a instituição psiquiátrica e a sociedade. Também foi colocada a questão do financiamento, contrapondo-se ao antigo modelo de contratação de leitos nos hospitais privados, mostrando a necessidade de se investir nos serviços comunitários de atenção à saúde mental. (MACHADO, 2006).

Em dezembro de 1987, ocorreu o II Congresso Nacional dos Trabalhadores de Saúde Mental, em Bauru. Deste evento surgiu a palavra de ordem em relação a esse tema: o dia 18 de maio foi marcado como Dia Nacional da Luta Antimanicomial. A partir de então, passou-se a defender a extinção do hospital psiquiátrico e a implantação de serviços substitutivos para a atenção em saúde mental. (AMARAL, 2006).

A construção desse novo modelo no Brasil baseou-se, em grande medida, na ideologia da desinstitucionalização italiana, a qual visa reintegrar a pessoa com transtorno mental na sociedade, conferindo-lhe, novamente, os direitos de cidadania. Amarante e Rotelli (1992) deixam claro o interesse brasileiro pela reforma italiana, afirmando que esse:

[...] é comprovado através de significativas experiências que estão sendo desenvolvidas em alguns serviços, instituições ou ainda municípios, onde tem 
sido esta linha prático-teórica mais importante a orientar a condução da política assistencial. (AMARANTE; ROTELLI, 1992: 41).

E esta perspectiva, embora não tenha sido a única referência para a construção da Reforma Psiquiátrica brasileira, foi muito importante nesse processo, como afirmam Amarante e Rotelli (1992):

\begin{abstract}
Seria redutor ou errado dizer que a linha iniciada por Basaglia tenha sido a única a informar os movimentos de transformação da prática psiquiátrica no Brasil, mas pode-se afirmar sem sombra de dúvida que tem sido a mais importante para aqueles que se empenham na verdadeira transformação da instituição psiquiátrica, a exemplo dos Movimentos de Trabalhadores em Saúde Mental em suas mais variadas cores e momentos de suas trajetórias. (AMARANTE; ROTELLI, 1992: 48).
\end{abstract}

A propagação e reprodução das idéias do MTSM em todo o país, colocando em evidência a questão psiquiátrica, alcançaram a consciência da sociedade em torno desse problema, pois, “de forma competente, tais movimentos fazem ver à sociedade como os loucos representam a radicalidade da opressão e da violência imposta pelo estado autoritário.” (AMARANTE; ROTELLI, 1992: 48).

Os encontros realizados em torno dessa questão consolidaram ainda mais esse movimento, que tinha por lema a construção de uma sociedade sem manicômios, e passou a ser chamado de Movimento Nacional da Luta Antimanicomial (MNLA); esse grupo começou a se organizar em redes com outros segmentos da sociedade civil, como Organizações Não Governamentais (ONGs), grupos de familiares dos pacientes, entre outros, e passou a realizar encontros nacionais que discutiam a construção de uma nova cidadania para as pessoas com transtorno mental, assim como a ampliação dos seus direitos. (AMARAL, 2006).

O primeiro desses encontros aconteceu em 1993 e provocou um debate em torno da prática médica em saúde mental, da necessidade de criar novas formas de terapia, proteger os direitos e repensar a representação dessas pessoas na sociedade, garantindolhes a cidadania sem negar-lhes o direito à diferença; a idéia era desconstruir a noção de que só é possível inserir-se na sociedade através da produção, enfatizando a importância do convívio social. (AMARAL, 2006).

O setor privado de atendimento psiquiátrico apresentou resistência ao novo modelo que começava a ser construído a partir desses debates, pois " a mudança desse estado de coisas vem colocar em risco seus interesses de hegemonia do saber ou de produção de capital na exploração da mercadoria 'doença mental.'” (AMARANTE; 
ROTELLI, 1992: 43). É importante citar que, quando o autor fala de "hegemonia do saber”, está se referindo também aos centros universitários, os quais entram como um desses agentes de recusa da reestruturação dos serviços psiquiátricos. Essa posição demonstra a tentativa da categoria médica em manter a hegemonia do seu saber, uma vez que o novo modelo de atendimento em saúde mental, além de propor a participação indispensável das outras áreas da saúde no tratamento psiquiátrico, passa a olhar o paciente na sua totalidade, e não apenas com o enfoque na doença; além disso, os psiquiatras, em sua maioria, atuavam nas unidades particulares de internação, as quais eram constantemente denunciadas pelos maus-tratos infligidos às pessoas em tratamento. (AMARAL, 2006).

Em seqüência ao primeiro encontro, aconteceu em 1995 o II Encontro Nacional, cujo tema era Cidadania e Exclusão, reforçando o debate sobre a desconstrução da representação social dessas pessoas, visando reconhecer a subjetividade do sujeito como elemento que lhe garanta cidadania, independente da sua produção. (AMARAL, 2006).

A proposta do MNLA era suprimir a internação, construindo respostas inteiramente substitutivas ao modelo manicomial, desenhando as bases da Reforma Psiquiátrica brasileira.

\section{3- Política de Saúde Mental na atualidade}

O resultado da luta dos movimentos contra o modelo manicomial, as influências internacionais contra o paradigma psiquiátrico, a proposta de construção de um novo modelo de atenção à saúde mental, além da emergência de um novo sistema de saúde geral, engendraram a criação de uma política específica para a saúde mental, a fim de garantir a atenção ampla e integral às pessoas com transtorno mental.

A alteração desse modelo foi chamada de Reforma Psiquiátrica, a qual não só faz uma crítica ao modelo hospitalocêntrico de atenção, mas visa à extinção dos hospitais psiquiátricos e, dessa forma, o estabelecimento de novos serviços, que desconstruam os anéis de violência e exclusão legitimadas pelas instituições manicomiais. (LOBOSQUE, 2001). 


\subsection{1- Marcos legais da implementação da Política de Saúde Mental}

A construção de uma política que regulamentasse os serviços de saúde mental tornou-se indispensável na medida em que era necessário transformar o aparato legal da exclusão expresso nas antigas legislações sobre o tema ${ }^{16}$, nas quais os loucos eram excluídos da sociedade por conta de sua incapacidade para o trabalho e periculosidade social. Nesse contexto, Fagundes (1992) afirma que:

[...] o desafio é tornar a saúde mental uma questão social incluída nas agendas do legislativo, do executivo, do judiciário, dos movimentos sociais, populares e sindicais em todos os níveis: local, municipal, estadual e federal. (FAGUNDES, 1992: 61).

Assim, foram construídas legislações que regulamentaram o novo modelo de atendimento em saúde mental, baseado em serviços substitutivos.

Uma das primeiras medidas nesse aspecto foi a proibição da abertura de novos leitos em hospitais psiquiátricos, feita pelo Ministério da Saúde por meio do Projeto Delgado, de 1989. Além disso, esse projeto previa a extinção dos manicômios e a desospitalização progressiva das pessoas com transtorno mental, a partir da regulamentação da internação compulsória e da criação de serviços substitutivos. (DELGADO, 2007).

A partir da década de 90 o processo de Reforma Psiquiátrica ganhou mais força na América Latina e, consequentemente, no Brasil, pois foi realizada, em novembro de 1990, a Conferência Regional para a Reestruturação da Assistência Psiquiátrica no Continente, organizada pela Organização Pan-Americana de Saúde, a qual resultou na assinatura da Declaração de Caracas.

Essa declaração determina que a reestruturação da assistência psiquiátrica nos sistemas locais de saúde deve permitir a promoção de modelos alternativos de atendimento, centrados na comunidade e articulados com as redes sociais. Determina também que deve haver uma revisão crítica do papel dos hospitais psiquiátricos na execução dos serviços, além de ajustar as legislações federais e locais em torno dessa questão.

A Declaração de Caracas também estabelece que a capacitação dos profissionais em saúde mental deve ser feita dentro dos princípios do modelo psicossocial de atendimento.

${ }^{16}$ Como exemplo, tem-se o já citado Decreto nº 24.559/34. 
A partir de então, houve um grande impulso para a criação de legislações em saúde mental que contemplassem as reivindicações dos movimentos pela Reforma Psiquiátrica no Brasil. A articulação entre esses atores da luta antimanicomial se fez representar pelo projeto de lei do deputado Paulo Delgado de 1987, o qual havia sido apresentado em 1989 a diversas Comissões da Câmara, mas tramitou no Senado de 1991 a 1999, quando foi aprovado; o mesmo foi sancionado apenas em 2001, tornandose a Lei 10.216, que finalmente regulamentou a Reforma Psiquiátrica no Brasil.

A tramitação desse projeto de lei refletiu o conflito de interesses entre os donos de clínicas psiquiátricas particulares e hospitais conveniados, e os movimentos sociais a favor da extinção desse modelo de atendimento por uma proposta alternativa. Em 1991, por exemplo, a Federação Brasileira de Hospitais encaminhou um abaixo-assinado ao Congresso pedindo o adiamento da votação da lei, para que pudesse ser modificada de acordo com seus interesses. Porém, quando da aprovação da lei, em 2001, foi possível suprimir os artigos incluídos por esse grupo, os quais aprovavam medidas como o repasse de recursos públicos para a construção de novos hospitais psiquiátricos. (AMARAL, 2006).

A Lei 10.216/01, como promulgada, “dispõe sobre a proteção e os direitos das pessoas portadoras de transtornos mentais e redireciona o modelo assistencial de saúde mental.” (BRASIL, 2002: 15). Essa lei determina como direitos dessas pessoas, entre outros, a humanidade e respeito no tratamento, com vistas a alcançar a sua recuperação pela inserção na família, no trabalho e na comunidade. Também determina que o tratamento seja o menos invasivo possível e, preferencialmente, oferecido em serviços comunitários de saúde mental.

Em seu artigo $4^{\circ}$ deixa explicita a proposta da desinstitucionalização, quando declara que "a internação, em qualquer de suas modalidades, só será indicada quando os recursos extra-hospitalares se mostrarem insuficientes”, determinando que o tratamento, no caso de internação, deverá visar à reinserção do paciente na sociedade, através de uma atenção integral em todos os aspectos. (BRASIL, 2002: 16). Além disso, esse mesmo artigo proíbe a internação em instituições asilares, sendo prevista pelo artigo $5^{\circ}$, para os casos de pessoas que perderam seus vínculos sociais, ou que é dependente da instituição, “política específica de alta planejada e reabilitação psicossocial assistida”. (BRASIL, 2002: 16). 
A Lei 10.216/01 foi o grande impulso para a consolidação da Reforma Psiquiátrica no Brasil, pois vários serviços foram regulamentos a partir dessa, sendo consolidados como política nacional do Estado para a saúde mental.

Entre 11 e 15 de dezembro de 2001 aconteceu em Brasília a III CNSM, a qual estabeleceu, em seu relatório final, diretrizes para a execução da Política de Saúde Mental, a capacitação dos profissionais atuantes nessa área, o financiamento da Política, a acessibilidade aos serviços e informações, os direitos de cidadania dos usuários e o controle social, a partir da participação da população nos conselhos de saúde mental. (SUS, 2002).

A III CNSM foi convocada pelo Ministério da Saúde, através da Resolução n. ${ }^{\circ}$ 310/CNS, de 04/04/2001, por solicitação do Plenário do Conselho Nacional de Saúde. Nos meses de preparação da Conferência foram realizadas 163 Conferências Municipais e 173 Micro-regionais e Regionais, além de diversas plenárias nos locais onde não havia como fazer as Conferências. (SUS, 2002).

Essa grande mobilização em torno da III CNSM fez que esta impulsionasse, em grande medida, a aplicação da Lei 10.216/01.

[...] é a III Conferência Nacional de Saúde Mental, com ampla participação dos movimentos sociais, de usuários e de seus familiares, que fornece os substratos políticos e teóricos para a política de saúde mental no Brasil, fortalecendo o processo de construção e consolidação do modelo psicossocial de atenção em saúde mental no Brasil. (BRASIL, 2005: 9).

Assim, vários serviços foram criados e fortalecidos, em nível nacional, como os Serviços Residenciais Terapêuticos (SRTs) e os Centros de Atenção Psicosocial (CAPS).

Os SRTs já haviam sido regulamentados pela Portaria nº 106 de 11 de fevereiro de 2000, mas foram consolidados a partir da Lei 10.2016/01. De acordo com essa lei os SRTs são casas localizadas no espaço urbano, constituídas para responder às necessidades de moradia de pessoas com transtorno mental grave que perderam os vínculos familiares e sociais, principalmente, as egressas de hospitais psiquiátricos ou de custódia. O objetivo dessas casas, além de oferecer moradia, é auxiliar a pessoa com transtorno mental na sua reintegração social, sendo garantido seu direito de circular pela cidade e pela própria casa, tendo resguardada sua privacidade e respeitados suas vontades e hábitos. (BRASIL, 2005). 
O número de usuários em cada casa pode variar de uma pessoa até um grupo de oito pessoas, que deverá contar com suporte profissional sensível às demandas e necessidades de cada um. Os SRTs deverão estar vinculados a um CAPS ou a um serviço ambulatorial. (BRASIL, 2005).

Em conseqüência da Lei 10.216/01, vários hospitais psiquiátricos do país foram fechados, por não atenderem os critérios básicos de assistência então estabelecidos. Ao mesmo tempo, foram sendo implantados serviços substitutivos com base comunitária: os CAPS.

Esses foram regulamentados por meio da Portaria da Secretaria Nacional de Assistência à Saúde $n^{0}$ 224, de 29 de janeiro de 1992, como unidades de saúde locais/regionalizadas destinadas a oferecer atendimento entre o regime ambulatorial e a internação, devendo ser constituídos por equipes multiprofissionais. Esta portaria também estabelece que o CAPS pode constituir-se em porta de entrada da rede de serviços para as ações relativas à saúde mental, por estar integrado à comunidade. (BRASIL, 2005).

A Portaria $\mathrm{n}^{\circ}$ 336, de 19 de fevereiro de 2002, fortaleceu a idéia do atendimento em saúde mental pelos CAPS, diferenciando-os em três tipos: CAPS I, para cidades com população entre 20.000 e 70.000 habitantes; CAPS II, para cidades com população entre 70.000 e 200.000 habitantes; ou CAPS III, para cidades com população acima de 200.000 habitantes, além das especialidades álcool e drogas (CAPS-ad) e infantojuvenil (CAPS-i), dependendo do local onde será implantado e das demandas da comunidade. O trabalho se dá pela atenção ambulatorial em Psicologia e Psiquiatria, atendimento psicoterápico individual infantil e adulto, e também atenção grupal, desenvolvido por meio de oficinas terapêuticas. (BRASIL, 2002).

A desvinculação com o hospital psiquiátrico é esboçada pelo artigo $3^{\circ}$ desta portaria, o qual estabelece que os CAPS devem ser independentes de qualquer estrutura hospitalar, e, mesmo que localizem-se dentro do conjunto arquitetônico de algum hospital geral, devem ter equipe própria de atendimento e ser independentes da estrutura física do hospital. (BRASIL, 2002).

Além dessas formas de atendimento, a rede de saúde mental prevê também a abertura de leitos em hospitais gerais que possibilitem o atendimento aos pacientes em situação de crise, facilitando o acesso das famílias às emergências psiquiátricas, uma 
vez que essas estariam distribuídas por toda a rede de saúde; e também, a utilização dos serviços dos Hospitais-Dia (HDIA).

Esses foram aprovados no âmbito do SUS em 2001, por meio da Portaria $\mathrm{n}^{\circ}$ 44/01 do Ministério da Saúde, e são definidos como:

[...] a assistência intermediária entre a internação e o atendimento ambulatorial, para realização de procedimentos clínicos, cirúrgicos, diagnósticos e terapêuticos, que requeiram a permanência do paciente na Unidade por um período máximo de 12 horas. (BRASIL, 2001, Art. $2^{\circ}$ ).

Os Hospitais-Dia destinados à atenção em saúde mental representam um serviço de internação parcial, os quais são divididos em quatro categorias: a) serviços alternativos à hospitalização psiquiátrica; b) atendimento aos pacientes egressos de internação fechada; c) complemento ao tratamento ambulatorial, com atividades terapêuticas; e, d) reabilitação de pacientes que têm transtorno mental cronificado.

Entre os programas de saúde mental implementados, uma das maiores estratégias de desinstitucionalização, reintegração familiar e emancipação das pessoas com transtorno mental é o Programa De Volta para Casa, criado pelo Ministério da Saúde por meio da Lei 10.708, de 31 de julho de 2003.

O Programa busca contribuir efetivamente para o processo de inserção social dessas pessoas através do pagamento de um auxílio-reabilitação no valor de R\$ 240,00, pago a pacientes egressos de instituções psiquiátricas após terem permanecido internados por, no mínimo, dois anos, e cuja situação clínica e social não justifique a permanência no hospital. (BRASIL, 2003). Além disso, é um incentivo para famílias que não possuem condições de sustentar mais uma pessoa, a qual, em muitos casos, já passou décadas de internação.

Em linhas gerais, o programa é uma alternativa de atenção especializada desses pacientes, incentivando seu tratamento no âmbito familiar, dentro do novo direcionamento dado às políticas de saúde mental atualmente.

Todas essas medidas de transformação do modelo manicomial implementadas nacionalmente fazem parte da Política Nacional de Saúde Mental atual. No entanto, a execução desses serviços varia a nível local, ao mesmo tempo em que também são criados outros serviços, dependendo de cada território. 


\section{4- Reforma Psiquiátrica no Distrito Federal}

Após essa descrição da Política de Saúde Mental no Brasil e os serviços implementados, esse tópico analisará como estes serviços têm sido desenvolvidos no DF e, posteriormente, no Hospital São Vicente de Paulo (HSVP), para que seja possível conhecer as contradições da implementação da Reforma Psiquiátrica dentro de uma institução de Psiquiatria.

\subsection{1- Construção da Reforma Psiquiátrica no Distrito Federal}

O marco inicial do atendimento psiquiátrico no DF é a inauguração da Unidade Psiquiátrica do Hospital de Base do Distrito Federal (HBDF), ainda na década de 60, a qual foi uma das primeiras unidades implantadas em hospitais gerais do Brasil. Nessa eram atendidas pessoas com transtorno mental em situação de crise, priorizando-se a internação de pacientes em primeiro surto ou em quadros psicóticos agudos. Aqueles considerados crônicos eram encaminhados, principalmente, ao Sanatório Espírita de Anápolis, no Goiás, o qual era conveniado com a Fundação Hospitalar do DF (FHDF), além de outras clínicas também conveniadas. (MACHADO, 2006).

Em 1976 foi inaugurado em Taguatinga, cidade satélite do DF, o Hospital de Pronto Atendimento Psiquiátrico (HPAP), o qual, segundo Machado (2006), “representou, em certa medida, um retrocesso à perspectiva de vanguarda introduzida pela inauguração da Unidade Psiquiátrica do Hospital de Base, que propunha atendimento de pacientes psiquiátricos em hospital geral.” (MACHADO, 2006: 46).

Essa inauguração foi resultado da falta de uma proposta específica para a saúde mental no DF, pois, em todo o país, crescia a força dos movimentos sociais contra o modelo manicomial de atenção. (MACHADO, 2006).

Após 11 anos da criação do HSVP, em 1987, foi criado o Instituto de Saúde Mental (ISM), o qual se estabeleceu como alternativa substitutiva ao modelo manicomial, com a implementação de atendimento ambulatorial e a criação de um HDIA em suas dependências.

Como reflexo da formação do MNLA, em 1990, trabalhadores da saúde mental do DF se organizaram e formaram, em 1991, o Movimento Pró-Saúde Mental do DF, o 
qual surgiu após o I Encontro dos Profissionais de Saúde Mental do DF, em abril do mesmo ano. (MACHADO, 2006).

Esse movimento participou ativamente da constituição da Lei Orgânica do Distrito Federal, a qual foi de grande importância no que diz respeito à saúde mental, pois em seu artigo 211 estabelece que o Poder Público tem o dever de promover e restaurar a saúde psíquica dos indivíduos por meio de serviços de saúde oferecidos em todas as etapas de tratamento, respeitando os direitos dos usuários. Esta lei já previa a substituição do modelo manicomial pela utilização de Hospitais-Dia, leitos em hospitais-gerais, lares abrigados, centros de convivência e atendimento ambulatorial. Além disso, determinou que os hospitais-gerais incluíssem unidades de internação psiquiátrica. (BRASIL, 1993).

Em 1995 o ISM credenciou-se no Ministério da Saúde como CAPS, tornando-se o primeiro do DF. Neste mesmo ano aconteceu o I Fórum de Saúde Mental do DF, onde foi elaborado o Plano Diretor de Saúde Mental, apresentado à FHDF, como proposta de execução da saúde mental nessa unidade da federação. (MACHADO, 2006).

Ainda nesse ano foi criada pela FHDF a Coordenadoria de Saúde Mental do Distrito Federal (COSAM/DF), a qual tem como objetivo:

Propor e participar da formulação de políticas públicas de saúde, planos e programas estratégicos para a Saúde Mental do DF, compatibilizando-as com as diretrizes do Ministério da Saúde. Promover e participar de estudos que visem à reorientação e reestruturação da Saúde Mental, buscando a oferta de ações de saúde aos portadores de transtornos psiquiátricos e psicológicos; além de propor e acompanhar a aplicação de indicadores para a avaliação dos Programas de Saúde Mental. (GDF, 2007).

Entre suas principais funções, está a capacitação dos profissionais da área através de palestras e cursos de atualização profissional.

Também em 1995 foi aprovada a Lei Distrital nº 975, a qual fixa as diretrizes para a atenção em saúde mental no DF em torno da redução progressiva de leitos em hospitais psiquiátricos e clínicas especializadas, direcionando as ações para serviços como os CAPS, Residências Terapêuticas, HDIA, Oficinas Terapêuticas, entre outros dispositivos, além de determinar, no seu Art. $3^{\circ} \S 2^{\circ}$, o prazo de quatro anos para a extinção de todos os leitos em hospitais e clínicas especializadas, a partir da publicação da lei. (BRASIL, 2002). Dessa forma, até 1999 todos os leitos em hospitais psiquiátricos e clínicas asilares deveriam ter sido fechados. No entanto, não é isso que a realidade de Brasília vai mostrar. 
Em 1996 foi implantado, na estrutura do Centro de Orientação MédicoPsicopedagógica (COMPP), o segundo CAPS do DF, o qual atende o público infantojuvenil. O COMPP é um serviço de atendimento à saúde mental de crianças e adolescentes em vários níveis de sofrimento mental e emocional, como vítimas de violência ou abuso, depressão, autismo e com dificuldade de aprendizado. A família também é incluída no tratamento, por meio de terapia individual ou em grupo. (GDF, 2006).

No ano seguinte foi realizado o II Fórum de Saúde Mental do DF, e inaugurado o Serviço de Saúde Mental do Hospital Materno-Infantil de Brasília. Em 1998 aconteceu o I Encontro Nacional dos Serviços Substitutivos em Saúde Mental, onde grupos de todo o país apresentaram propostas de serviços alternativos ao modelo manicomial, fortalecendo a Reforma Psiquiátrica no Brasil e no DF. (MACHADO, 2006).

Nesse mesmo ano a FHDF criou o Curso de Especialização em Saúde Mental, como uma iniciativa de capacitação dos profissionais que atuavam nessa área, voltado para o modelo psicossocial de atenção. No entanto, após a segunda turma esse curso foi extinto, e, com ele, mais uma possibilidade de formar profissionais comprometidos com a implantação da Reforma Psiquiátrica. (MACHADO, 2006).

A partir de 1999, com a mudança do governo local, a Reforma Psiquiátrica no DF experimentou uma grande estagnação na implementação de serviços, permanecendo com velhas instituições, e reproduzindo o modelo manicomial na prática de muitas delas.

Em maio de 2000 um grupo de alunos do Curso de Especialização em Saúde Mental, juntamente com usuários dos serviços de saúde mental do DF, artistas e estudantes, organizaram o "Varal da Casa Verde", uma exposição de pinturas, esculturas e poesias, cuja abertura foi o Colóquio “Loucura e Arte”. Essa junção de diversos segmentos ligados à saúde mental em busca de uma nova perspectiva sobre a loucura, culminou na criação, em março de 2001, da ONG em saúde mental Inverso, a qual, desde então, "tem realizado ações políticas, culturais, e de cunho terapêutico, no sentido da defesa do ideário da Reforma Psiquiátrica.” (INVERSO, 2007).

Ainda no ano 2000, a FHDF foi transformada na Secretaria de Estado da Saúde (SES/DF), e o controle orçamentário e financeiro da saúde, então, foi passado do Fundo 
da Saúde para a Secretaria da Fazenda. Essa medida tem provocado ainda atualmente o crescente desabastecimento das unidades de saúde, bem como a precarização dos seus serviços e a carência de recursos humanos nas instituições. (MACHADO, 2006).

Em 2003 foi desativada a Clínica de Repouso Planalto, antiga instituição psiquiátrica que atendia no DF por meio de convênio com a SES/DF, onde foram constatadas pelo Ministério Público condições precárias de estrutura física, além de maus-tratos aos usuários. Nessa clínica havia 146 leitos mantidos pelo SUS, os quais foram extintos com a desativação da mesma, e os pacientes distribuídos pelos serviços disponíveis.

Em 2005 inaugurou-se um CAPS-ad na cidade satélite do Guará, destinado a atender pessoas com sofrimento psíquico decorrente do uso de álcool e outras drogas. Em novembro e dezembro de 2006 foram inaugurados, respectivamente, um CAPS-ad, em Sobradinho, e um CAPS II em Taguatinga. (SES, 2006).

Dessa forma, atualmente, existem sete CAPS funcionando no DF, os quais são: um CAPS I no ISM; um CAPS-i no COMPP; um CAPS-ad no Guará, um CAPS II no Paranoá, um CAPS-i no Adolescentro (Centro de Referência, Pesquisa, Capacitação e Atenção Integral à Adolescência e Família que funciona no Centro de Saúde 6 da Asa Sul desde 2001), semelhante ao CAPS-ad, especializado na infância e adolescência; um CAPS-ad, em Sobradinho; e um CAPS II em Taguatinga. Além disso, a SES/DF conta com 24 leitos de Psiquiatria no HBDF; 128 leitos, no HSVP, sendo 71 para internação e 57 para o serviço de emergência; ambulatórios em hospitais gerais (HBDF, Hospital Regional da Asa Norte, Hospital do Paranoá e outros), e o ambulatório do próprio HSVP. (GDF, 2006).

Além disso, existe no DF a Ala de Tratamento Psiquiátrico para o cumprimento de medidas de segurança para pessoas com transtorno mental autoras de atos infracionais.

Em 2006 havia a previsão de criação de residências terapêuticas nas regiões onde já havia CAPS ou serviços de saúde mental implantados, complementando a rede de atenção. A princípio seriam instaladas três SRTs, nas cidades de Taguatinga, Samambaia e Riacho Fundo, próximas ao HSVP e ao ISM. (DF, 2006). No entanto, essa proposta ainda não foi concretizada, deixando essa brecha no atendimento às pessoas com transtorno mental crônico e sem referência familiar. 
Apesar da implantação dos CAPS e de outros serviços de saúde mental, recentemente, a Reforma Psiquiátrica no DF ainda está bastante atrasada com relação à legislação e a experiência de outros estados brasileiros, pois a quantidade de serviços oferecidos não é suficiente para atender à demanda em saúde mental, além da inexistência de alguns serviços, como os leitos em hospitais gerais, os quais só existem no HBDF, e as residências terapêuticas.

As mudanças de governo têm ocasionado a descontinuidade das políticas públicas de saúde, e, consequentemente, estagnado a criação de novos serviços em saúde mental, inclusive no âmbito das organizações como a Inverso e o Movimento Pró-Saúde Mental, os quais não encontram espaço para consolidar suas propostas para um novo modelo de atendimento. (MACHADO, 2006).

Conceição Freitas, em matéria publicada em 15 de abril de 2007 pelo jornal de circulação eletrônica CorreioWeb, afirma que o DF está em penúltimo lugar no ranking da COSAM federal em relação ao número de CAPS, residências terapêuticas, e outras modalidade de atenção em saúde mental. Essa realidade afirma a precariedade das condições dos serviços de atenção psiquiátrica no DF, onde o acesso à saúde mental ainda é escasso, e são violados os direitos dessas pessoas previstos na legislação vigente.

\subsection{2 - O Hospital São Vicente de Paulo}

O Hospital São Vicente de Paulo é uma instituição subordinada à SES/DF e, portanto, tem um caráter público, e produz serviços de atendimento ambulatorial, emergencial, tratamento contínuo (em oficinas ou na família) e internação na área da saúde mental.

O HSVP foi inaugurado em 1959, mas não foi desde o início voltado especificamente para a saúde mental. Sua história começa mesmo um ano antes, em 03 de outubro de 1958, quando a extinta Fundação das Pioneiras Sociais inaugurou um hospital volante, conduzido pela congregação religiosa das Filhas da Caridade de São Vicente de Paulo; devido aos resultados satisfatórios do atendimento realizado, este se transformou no primeiro Hospital Geral do Distrito Federal, sob a administração das Irmãs Vicentinas, que deram a ele o nome e a imagem do seu padroeiro - Hospital São Vicente de Paulo. (HSVP, 1994). 
A proposta inicial era fazer no local um posto de puericultura e oferecer um atendimento especializado em maternidade. Mas, ao longo dos anos 60, o hospital expandiu o número de funcionários e as especialidades oferecidas (Pediatria, Ginecologia-Obstetrícia, Odontologia e Cirurgia). Com a ampliação dos serviços e especialidades, em 1968 a FHDF rompeu o contrato de prestação de serviços com as Irmãs Vicentinas, que deixaram o hospital. Em 1969, a fundadora do Lar dos Velhinhos, pediu ao governador permissão para retirar a imagem do santo padroeiro do hospital e levou-a para aquela instituição. (HSVP, 1994).

O hospital continuou suas atividades junto à comunidade de Taguatinga; mas, nos anos 70, o mesmo transformou-se num repositório de pacientes com meningite, devido a epidemias no DF e região.

Em 1975, com a inauguração do Hospital Regional de Taguatinga (HRT), o HSVP foi desativado e passou por uma pequena reforma. No local do mesmo foi inaugurado, em 18 de maio de 1976, o Hospital de Pronto Atendimento Psiquiátrico (HPAP), devido à grande necessidade desse serviço, considerando o elevado crescimento populacional de Taguatinga e do DF, e a incapacidade dos hospitais-gerais em atender essa demanda.

Durante a primeira direção do HPAP, que perdurou até 1985, foram difundidos os princípios manicomiais e de internação prolongada para tratamento da doença mental. Já a seguinte diretoria do hospital tinha como proposta de ação devolver ao hospital seu caráter humanizado, resgatando sua história. (HSVP, 1994).

O primeiro passo, então, foi trazer de volta a imagem do padroeiro, o que aconteceu no dia 27 de setembro de 1985. Exatamente dois anos mais tarde, depois de uma longa campanha humanitária, foi também resgatado o antigo nome da instituição Hospital São Vicente de Paulo. Nesse período, o hospital teve inaugurado um novo ambulatório, e também, implantada a residência médica em Psiquiatria. (HSVP, 1994).

Na década de 90, foram promovidas significativas mudanças na instituição, como a implantação do Hospital O Dia e a criação das Oficinas Protegidas destinadas a pacientes com distúrbios psicóticos junto ao tratamento ambulatorial. O funcionamento dos mesmos deu-se a partir de fevereiro de 1993. 
Em abril de 1995 foi criada a Associação de Familiares, Amigos, Usuários e Profissionais da Saúde Mental (AFAGO) visando captar recursos e doações para os programas do hospital, bem como dar apoio às famílias e pacientes.

Nesse mesmo ano uma psiquiatra assumiu a direção do hospital e passou a investir em estratégias de atendimento no modelo psicossocial, como o redirecionamento da internação para o Hospital-Dia, as oficinas terapêuticas, atendimento ambulatorial, entre outros. A COSAM-DF participou desse processo propondo a transformação do HSVP em um CAPS, transferindo o serviço de emergência e internação para o HRT. (MACHADO, 2006). No entanto, essas medidas ainda não se concretizaram, mesmo depois de muitos anos da promulgação da Lei Distrital n 975/95, que estabelecia o prazo até 1999 para o fechamento de todos os leitos em hospitais psiquiátricos.

Em março de 2005, o hospital recebeu a visita da Comissão dos Direitos Humanos da Câmara Legislativa, a qual revelou o descaso com a saúde mental no HSVP e no DF.

A deputada distrital Érika Kokay, presidente da comissão, disse nessa ocasião que, embora esta fosse a quarta visita realizada ao hospital, a situação tem piorado, e que era necessário tomar medidas emergenciais para contornar essa situação. ${ }^{17}$

Foram encontradas irregularidades na estrutura física do prédio, como também a falta de medicamentos e material de trabalho. (RODRIGUES, 2006)

Três dias depois, o hospital recebeu outra visita, mas, dessa vez, do secretário de Saúde, José Geraldo Maciel, o qual estava acompanhado do diretor do Hospital São Vicente de Paulo, Mário Antônio Crispim; do subsecretário de Atenção à Saúde, Mário Sérgio Nunes; do subsecretário de Planejamento em Política da Saúde, Cleyton Camargo e do Coordenador de Saúde Mental do DF, Antonio Geraldo da Silva.

Aos mesmos foi apresentada a seguinte situação: falta de medicamentos na farmácia do hospital durante meses seguidos, falta de espaço para que os pacientes pudessem dormir e situações precárias de estrutura física. Enquanto os pacientes da emergência deveriam permanecer no hospital por apenas 48 horas, muitos, por falta de vagas na internação, ocupavam leitos da emergência por até 20 dias. A situação se mostrava precária, como exemplifica Rodrigues (2006):

\footnotetext{
${ }^{17}$ Notícia veiculada pelo sítio da Secretaria de Saúde do Governo do Distrito Federal, em 11/01/2006.
} 
Na ala subcrônica, onde os pacientes deveriam ficar por até 45 dias, muitos ficam indefinidamente porque não têm para onde ir. Nos corredores da ala subcrônica, os problemas de infra-estrutura são visíveis. Poças de água formadas pela água da chuva do dia anterior ainda estavam no chão. A ferrugem corroeu as portas de metal, formando pontas afiadas que representam risco à integridade física dos pacientes. O local que um dia foi reservado para o descanso dos médicos deu origem a duas enfermarias, criada com a colocação de apenas um tapume para dividir os espaços. (RODRIGUES, 2006).

O maior problema enfrentado pelo HSVP é justamente em relação à escassez de recursos financeiros e humanos, tendo em vista a imensa demanda que tem chegado nos últimos anos e que, além do serviço oferecido nessa instituição, somente há atendimento psiquiátrico emergencial no $\mathrm{HBDF}$, em número bem limitado, o que acarreta a superlotação do HSVP.

Atualmente há, em média, 92 mil prontuários ativos no HSVP, que registram diversos tipos de demandas, muitas das quais poderiam ser atendidas apenas com serviços ambulatoriais, expressando a insuficiência dos CAPS existentes para o atendimento. O HSVP conta com 128 leitos, sendo 71 para internação e 57 para o serviço de emergência. Oferece também atendimento ambulatorial e possui uma farmácia com medicamentos psiquiátricos para seus pacientes. Mesmo com todas as dificuldades já apontadas, existem no hospital alguns programas e projetos desenvolvidos por iniciativa de profissionais, que representam alternativas de atendimento psicossocial, na perspectiva da Reforma Psiquiátrica. 


\section{Capítulo 3}

\section{Pesquisa de Campo}

\section{1- $\quad$ Apresentação do campo de pesquisa}

O HSVP representa o serviço de maior referência em saúde mental no DF, pois agrega em um único espaço tratamento ambulatorial, serviço de emergência, internação e terapia. O atendimento aos usuários é coordenado pela Gerência de Atenção Médica e Assistencial, a partir dos Núcleos de Emergência, Enfermagem, Nutrição e Dietética, Farmácia, Serviço Social, Terapia Ocupacional, além da seção responsável pelo controle de infecção hospitalar. A partir desses Núcleos são constituídas as principais unidades do hospital: Ambulatório, Emergência, Alas de Internação, Programa Vida em Casa e Oficinas de Produção.

A demanda que chega ao hospital é constituída por pessoas acometidas por transtorno mental e seus familiares, e o atendimento varia de acordo com o serviço requerido.

O vínculo dos pacientes com a instituição é por tempo indeterminado, uma vez que, no novo modelo de saúde mental, não se trabalha com a perspectiva de cura, mas de manutenção de um quadro estável do transtorno, de forma a possibilitar a integração na sociedade, como afirmam Amarante e Torre (2001):

O objetivo dos novos serviços, caso procurem inscrever-se no processo de
rupturas - aqui entendidas no sentido epistemológico ou arqueológico, de
rompimento radical com determinado paradigma, ou de construção de um
novo paradigma - com o modelo anterior, é o de produzir estruturas ou
recursos que efetivamente não reproduzam as bases teórico-práticas do
modelo psiquiátrico clássico, que fundou a noção de doença mental como
sinônimo de desrazão e patologia, que fundou o manicômio como lugar de
cura e que fundou a cura como ortopedia e normalização. (AMARANTE;
TORRE, 2001: 33).

Atualmente, a porta de entrada da maioria dos usuários é a emergência do hospital, seguida pela internação, contrariando o estabelecido pela Lei 10.216/01, que, em seu Art. $4^{\circ}$ determina que a internação só pode ser indicada quando todos os outros serviços extra-hospitalares se mostrarem insuficientes. (BRASIL, 2002).

Considerando esse contexto, o HSVP foi escolhido como campo de pesquisa, tendo em vista seu histórico e as contradições atuais no atendimento oferecido aos usuários. 


\section{2 - Objetivos da pesquisa e metodologia utilizada}

A pesquisa buscou analisar a importância da capacitação em Reforma Psiquiátrica para a implementação de serviços pautados pelos princípios do modelo psicossocial de atendimento, por iniciativa dos profissionais, no âmbito de uma instituição que carrega o caráter do modelo manicomial de atendimento, o HSVP.

Dessa forma, a hipótese dessa pesquisa é que a capacitação dos profissionais em Reforma Psiquiátrica tem sido determinante para a estruturação dessa no âmbito do HSVP, por iniciativa dos próprios profissionais.

O interesse pela capacitação desses profissionais surgiu a partir da proposta do atual governo de expandir a rede de atenção em saúde mental, com a criação de vários CAPS e SRTs no DF e a transformação do HSVP em um desses CAPS. Questiona-se se esses profissionais estariam preparados para atuar no novo molde de atendimento em saúde mental. Além disso, a Lei distrital nº 975/95, define que:

Art. $8^{\circ}$ O Governo do Distrito Federal promoverá campanhas de divulgação periódicas para esclarecimento dos pressupostos da Reforma Psiquiátrica de que trata esta Lei, nos meios de comunicação.

Art. $9^{\circ}$ Todos os estabelecimentos de saúde deverão propiciar aos usuários pleno conhecimento do objeto desta Lei, bem como do Plano de Atenção à Saúde Mental do Distrito Federal previsto no art. $7^{\circ}$. [Grifo nosso].

Considera-se que os profissionais que atuam no hospital, que têm um contato cotidiano com os usuários, seriam os mais indicados para propiciar esse conhecimento da legislação aos mesmos. Essa primeira ação poderia resultar no empoderamento dos usuários e familiares em relação a essa questão, levando-os a reivindicar o disposto no artigo $8^{\circ}$, que é a divulgação da Reforma pela mídia; assim, a implementação da Reforma poderia ser fortalecida.

Para obter os dados necessários à análise a que se pretende essa pesquisa foram aplicados, em abril de 2006, quarenta e três (43) questionários estruturados a todos os profissionais, de várias seções do HSVP, que se mostraram disponíveis para responder. Esses questionários possibilitaram traçar um perfil dos mesmos, além de conhecer o nível de capacitação em Reforma Psiquiátrica que estes se atribuem e a participação em eventos ou cursos que tratem desse tema. Na época, foi afirmado pelo administrador do 
hospital que o corpo profissional estaria em torno de 242 pessoas; dessa forma, foram questionados $17,7 \%$ dos profissionais. Pela simplicidade do questionário, não foi necessário agendar a pesquisa, a qual foi realizada durante o horário de trabalho dos profissionais.

A segunda parte da pesquisa foi construída a partir de entrevista semiestruturada com os profissionais responsáveis pela implementação de serviços substitutivos dentro do HSVP, e de análise dos documentos de criação, estabelecimento de rotinas, plano de atuação, entre outros, referentes a alguns desses serviços. Essa fase foi realizada em novembro de 2007.

As dificuldades encontradas para a realização da segunda fase da pesquisa dizem respeito, em grande medida, à ausência dos profissionais no hospital, pois muitos cumprem horários diferenciados de trabalho, além de participar de atividades externas. Havia também alguns profissionais em férias ou licenças.

\section{3 - Apresentação e discussão dos resultados}

A partir da metodologia descrita anteriormente, a apresentação e discussão dos resultados estão divididas de acordo com as fases que se seguiram, discutindo-se, primeiramente, os resultados dos questionários aplicados aos profissionais e, posteriormente, as entrevistas com os profissionais responsáveis pela implementação dos serviços substitutivos no HSVP.

\subsection{1- Perfil dos profissionais questionados}

Como afirmado, foram questionados 43 profissionais de diversas áreas do HSVP. Quanto à idade dos profissionais questionados, foi encontrada a seguinte realidade: 


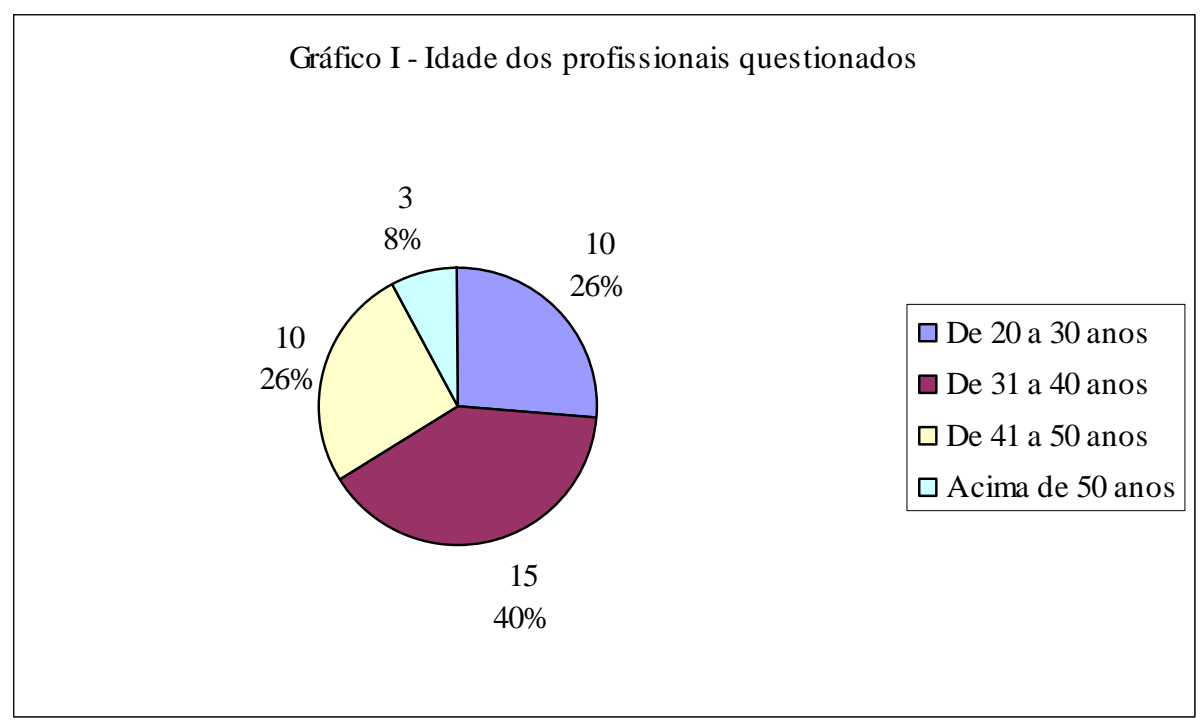

Os dados mostram que 10 pessoas afirmaram possuir entre 20 e 30 anos, constituindo 26\% do total dos profissionais. É interessante notar que, dentro dessa faixa etária está a maioria dos estagiários questionados de diversas áreas. Entre 31 e 40 anos tem a maioria dos profissionais que responderam à pesquisa, ou seja, $40 \%$ do total, somando 15 pessoas; 10 pessoas (26\%) afirmaram ter entre 41 e 50 anos; e 3 pessoas (8\%) estão com mais de 50 anos.

Relacionado à idade dos profissionais, em geral, está o tempo de serviço de cada um deles no HSVP:

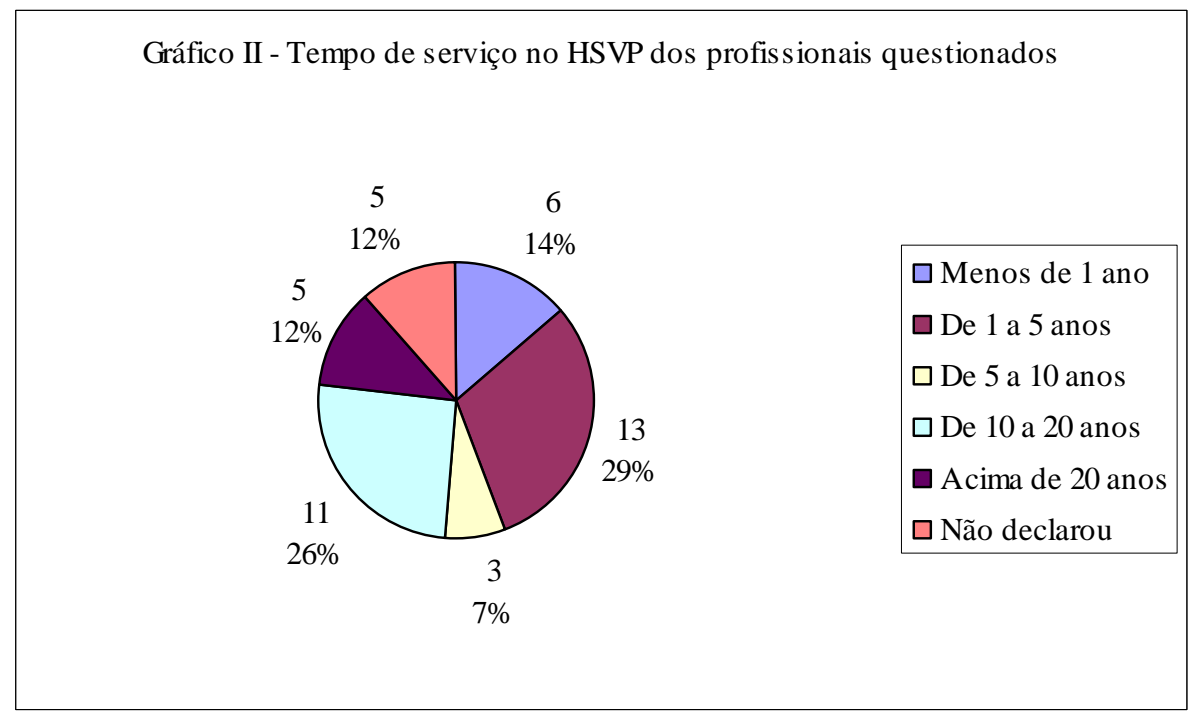

Os dados mostram que apenas 6 pessoas (14\%) estavam no hospital há menos de um ano; a maioria dos profissionais questionados - 13 pessoas (29\% do total) afirmaram trabalhar no HSVP entre 1 e 5 anos, grupo que representa várias categorias 
profissionais. Apenas 3 pessoas (7\%) trabalham no HSVP de 5 a 10 anos; 11 pessoas (26\%) trabalham no hospital entre 10 e 20 anos; acima de 20 anos, trabalham no hospital apenas 5 profissionais (12\%). As 5 pessoas (12\%) que não declararam o tempo de serviço no HSVP foram estagiários da área de Enfermagem, pois consideraram não fazer parte do quadro de funcionários.

Observa-se que 38\% dos profissionais que responderam ao questionário possuem mais de 10 anos de serviço no HSVP, mostrando que grande parte do quadro de funcionários já atuava na saúde mental antes da promulgação da Lei 10.216/01, que institui novos paradigmas para o atendimento em saúde mental. Ou seja, muitos profissionais vivenciaram as práticas manicomiais desenvolvidas no hospital quando esse ainda era o único modelo de atendimento previsto legalmente.

Os profissionais questionados fazem parte das seguintes seções:

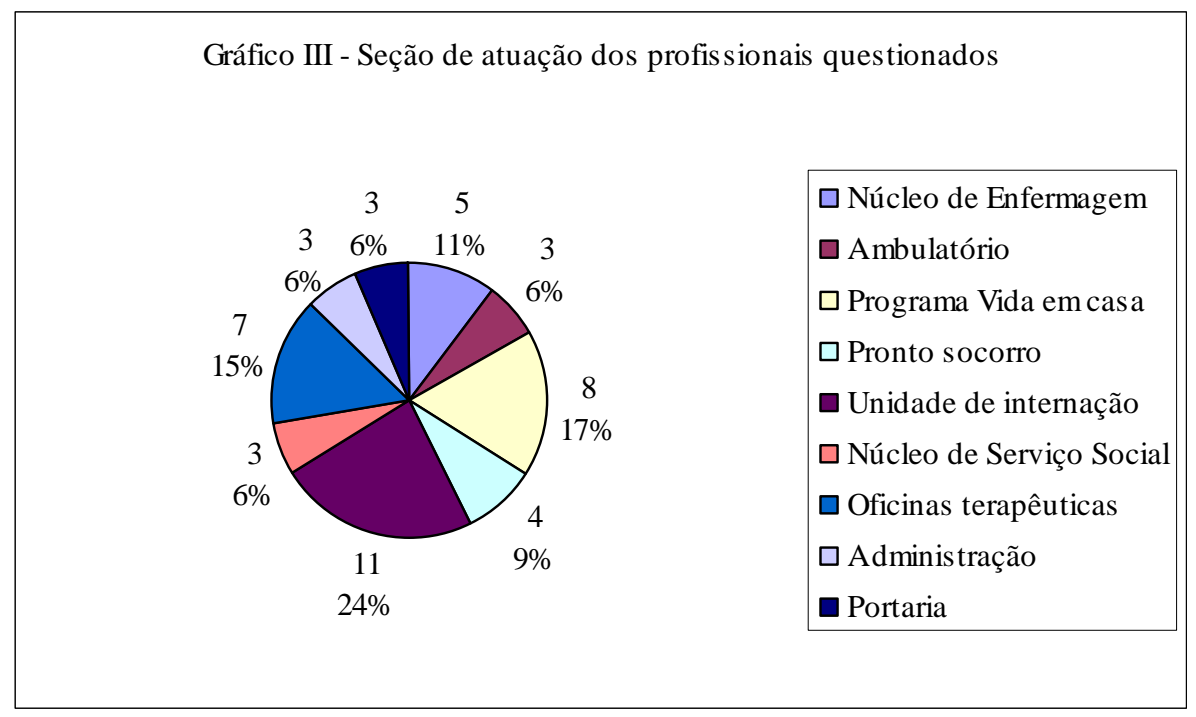

Dos profissionais questionados, 5 pessoas faziam parte do Núcleo de Enfermagem, o que equivale a $11 \%$ do total; no Ambulatório foi possível colher dados de 3 pessoas (6\%); do Programa Vida em Casa, foram questionados 8 profissionais (17\%); do Pronto-Socorro, 4 pessoas responderam ao questionário, (9\%); na Unidade de Internação foi respondida a maior parte dos questionários, somando 11 entrevistados, (24\%); 3 pessoas (6\%) faziam parte do Núcleo de Serviço Social; 7 pessoas (15\%), trabalhavam nas Oficinas Terapêuticas; da administração do hospital, foram questionadas 3 pessoas (6\%); o mesmo número de pessoas respondeu ao questionário aplicado nas Portarias. 
Observa-se a variedade de seções às quais pertenciam as pessoas que responderam aos questionários, sendo possível traçar o perfil de várias categorias profissionais atuantes no hospital. Dividindo os entrevistados por categorias profissionais, encontrou-se a seguinte realidade:

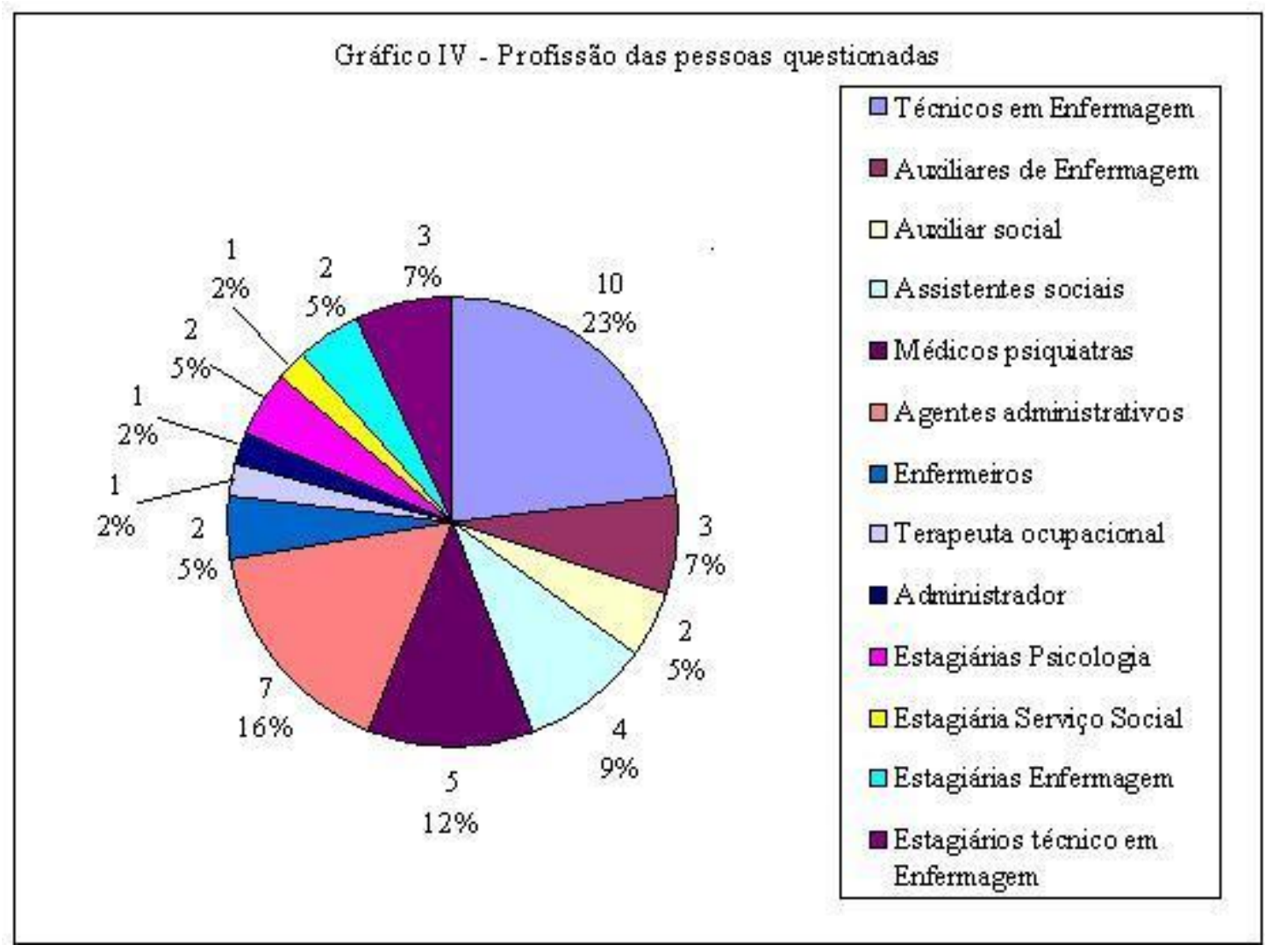

A maioria dos profissionais que responderam ao questionário, como se observa no gráfico, foi de técnicos em Enfermagem, representando 23\% do total (10 pessoas). Isso mostra a grande prevalência dessa categoria profissional sobre as demais que atuam no hospital. Entre os outros profissionais, se destacam os agentes administrativos, que foram 7 entrevistados (16\%) e as 4 assistentes sociais (9\%); no entanto, esse fato se explica pela facilidade de acesso a esses profissionais, pois permanecem em salas específicas, diferente de outros profissionais. Entre os demais, foram questionados 3 auxiliares de Enfermagem (7\%); 2 auxiliares sociais (5\%); 5 médicas psiquiatras (12\%); 2 enfermeiras (5\%); 1 terapeuta ocupacional (2\%); 1 administrador (2\%); 2 estagiárias de Psicologia (5\%); 1 estagiária de Serviço Social (2\%); 2 estagiárias de Enfermagem (5\%); e 3 estagiários de técnico em Enfermagem (7\%). 
A partir dessa diferenciação por categorias, é interessante dividir os profissionais de acordo com o sexo:

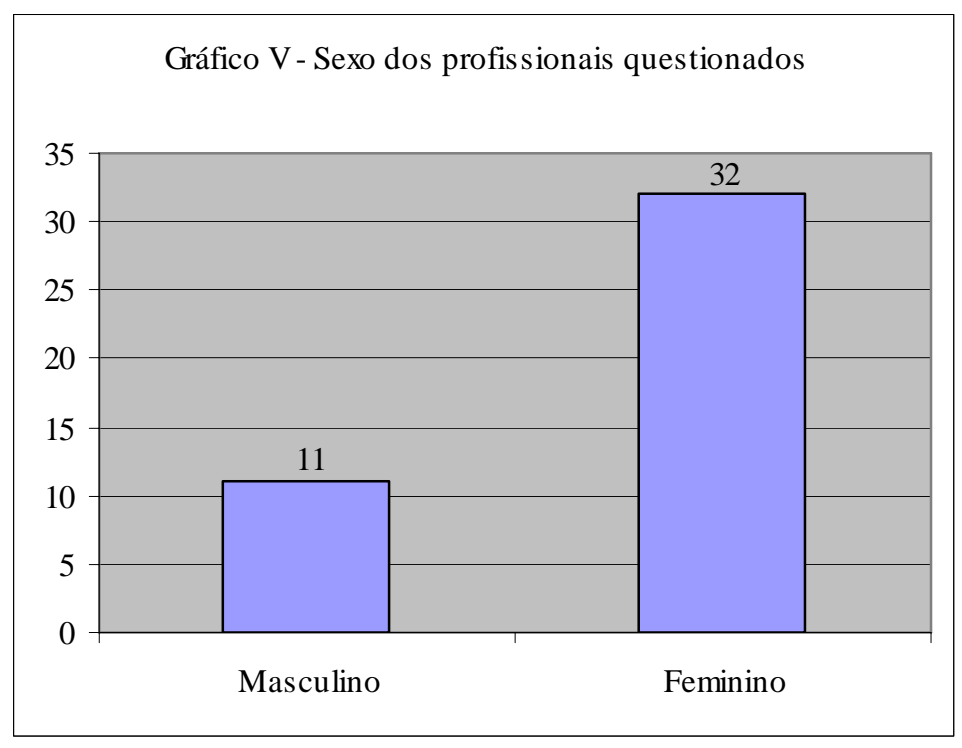

Observa-se a grande predominância de mulheres atuantes no hospital, o que se explica pela maioria dos questionários terem sido respondidos por profissionais da área da Enfermagem e da área social, como as auxiliares e técnicas em Enfermagem, enfermeiras e assistentes sociais. Ainda hoje, essas profissões são exercidas, em sua maioria, por mulheres.

Tendo traçado esse perfil dos profissionais, passa-se à segunda parte da análise dos questionários, referente à capacitação em Reforma Psiquiátrica.

\subsection{2- O conhecimento dos profissionais sobre a Reforma Psiquiátrica e a participação destes em eventos que tratam desse tema}

Os profissionais foram questionados quanto ao nível de conhecimento que eles se atribuíam sobre a Reforma Psiquiátrica, bem como a legislação atual da saúde mental e os serviços substitutivos ao modelo manicomial. Considerando todos os questionários, foram obtidos os seguintes dados: 


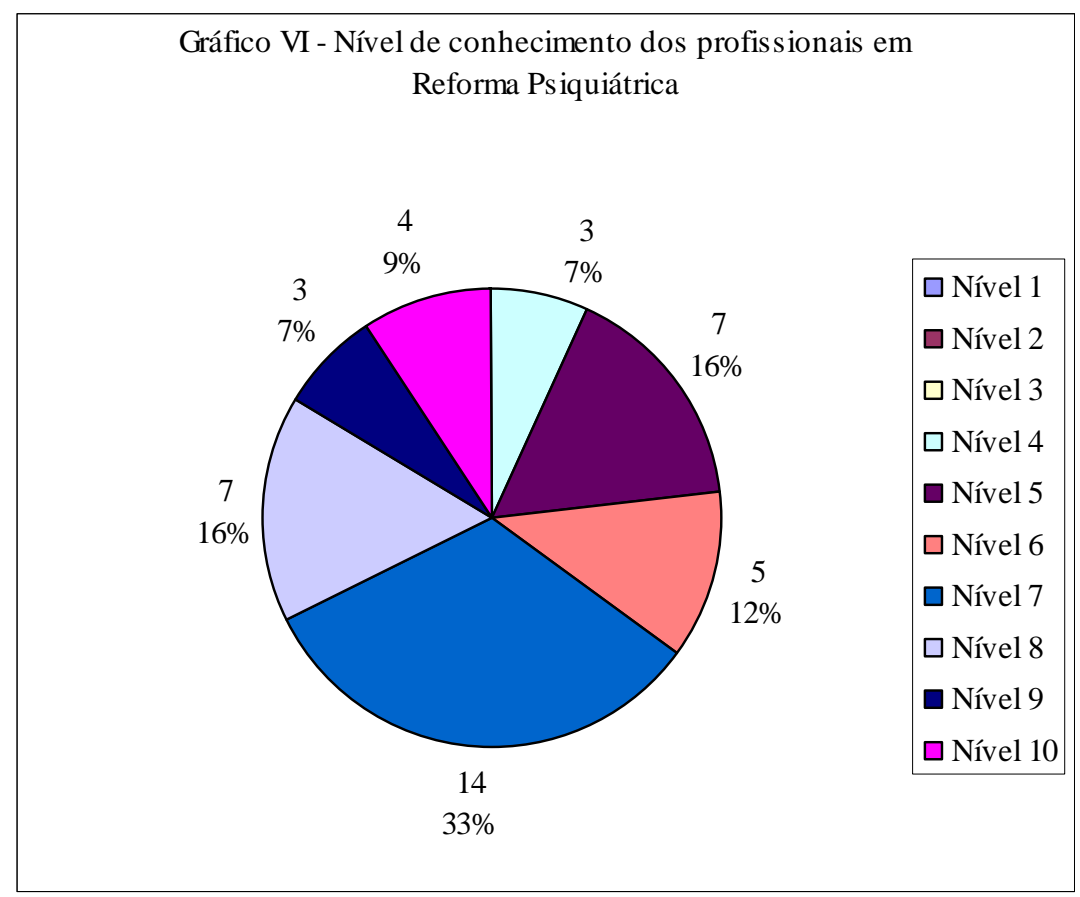

Os dados mostraram que a maioria dos profissionais atribuíam a si mesmos um nível elevado de conhecimento sobre a Reforma, considerando que o nível 7 foi respondido por 14 profissionais, o que representa 33\% do total. Os níveis 5 e 8 permaneceram iguais, escolhidos por 7 profissionais (16\%) cada. O nível 4 foi escolhido por 3 pessoas (12\%); 5 pessoas (12\%) marcaram nível 6; Os níveis mais elevados, 9 e 10, foram marcados por 3 pessoas (7\%), e 4 pessoas (9\%), respectivamente. Nenhum profissional atribuiu os níveis 1, 2 e 3 ao seu conhecimento acerca desse tema.

Embora esses dados revelem um nível elevado de conhecimento acerca da Reforma Psiquiátrica entre os profissionais do HSVP, quando perguntados sobre sua participação em cursos, eventos ou palestras acerca desse tema, o que se obtém é a seguinte realidade: 


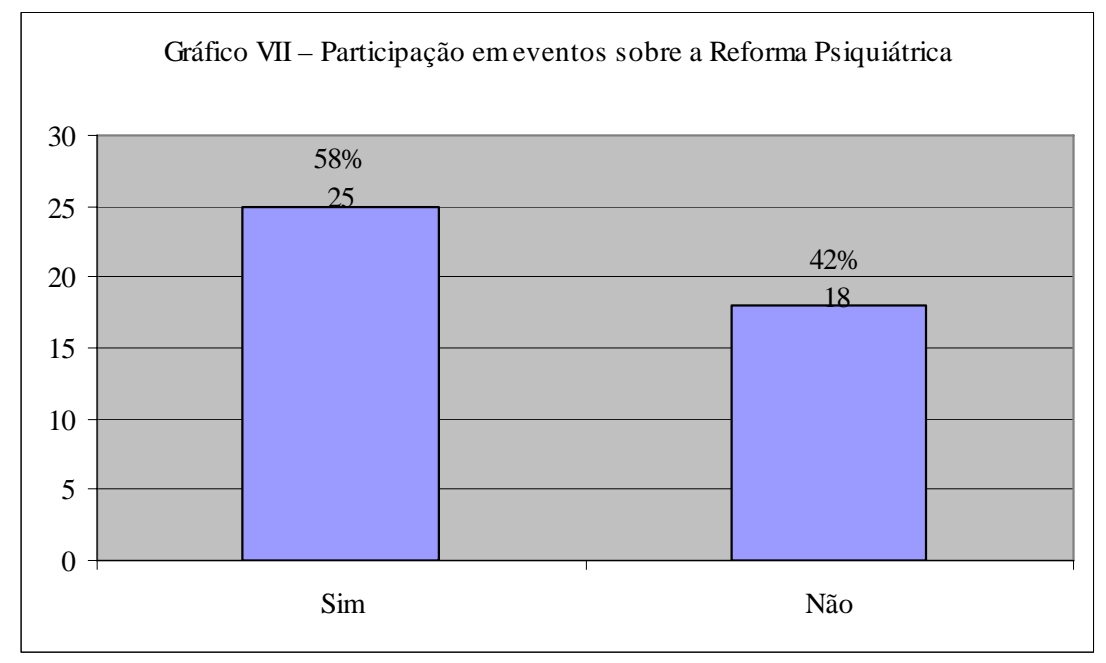

De acordo com o gráfico, a maioria dos profissionais já participou de eventos que tratassem desse tema; no entanto, considerando a especificidade da instituição e o tempo de implementação da lei que estabelece o novo modelo de atendimento, ainda é elevado o número de pessoas (42\% das questionadas) que nunca participaram de nenhum tipo de evento nessa área.

O quadro 1 mostra quais foram os eventos citados e a quantidade de profissionais que afirmaram ter deles participado. É importante notar que alguns profissionais citaram mais de um evento ou instituição realizadora, e também, que muitos apenas informaram ou a instituição ou o evento.

\begin{tabular}{|c|c|}
\hline \multicolumn{2}{|c|}{ Quadro 1 - Eventos informados pelos profisisonais. } \\
\hline Eventos informados & $\begin{array}{l}\text { Profissionais } \\
\text { participantes }\end{array}$ \\
\hline Não informou ou não lembra & 5 \\
\hline Associação Psiquiátrica de Brasília & 1 \\
\hline Congresso de Psiquiatria & 1 \\
\hline HSVP & 5 \\
\hline Fundação Oswaldo Cruz - RJ & 1 \\
\hline SES/DF & 2 \\
\hline Fórum sobre a Reforma & 3 \\
\hline ISM & 3 \\
\hline UNB & 1 \\
\hline Centro Universitário Uniceub - 18 de maio & 2 \\
\hline Câmara dos Deputados- Banalização da interdição judicial & 1 \\
\hline FEPECS - Curso de especialização em saúde mental & 1 \\
\hline Evento em Belo Horizonte & 1 \\
\hline Universidade Católica de Brasília & 1 \\
\hline Movimento Pró Saúde Mental & 1 \\
\hline
\end{tabular}


As instituições mais citadas foram o HSVP, por 5 pessoas, o ISM, por 3 pessoas, e a SES/DF, por 2 pessoas. Aquelas que colocaram o nome do evento citaram mais vezes o Fórum sobre a Reforma Psiquiátrica - 3 pessoas - e também o evento do dia 18 de maio, realizado pelo Centro Universitário Uniceub, lembrado por 2 pessoas. Os demais foram citados apenas por um dos profissionais, e cinco pessoas não informaram ou não lembraram qual foi o evento ou a instituição realizadora. A partir desses dados não foi possível conhecer a profundidade com que o tema foi abordado nos eventos, pois apenas uma pessoa especificou sua participação em Curso de Especialização.

Segundo o relatório de gestão 2003-2006 da Coordenadoria Geral de Saúde Mental, desde 2002 o Ministério da Saúde promove o Programa Permanente de Formação de Recursos Humanos para a Reforma Psiquiátrica, o qual, através de convênios com instituições de ensino, como universidades, incentiva, apóia e financia a implantação de núcleos de formação em saúde mental para a rede pública. Afirma-se no documento que, atualmente, estão em funcionamento 22 núcleos de formação em saúde mental espalhados pelo Brasil. No entanto, no anexo que especifica essa informação, mostra-se que, ao contrário de estados como São Paulo, Rio de Janeiro, Minas Gerais, Santa Catarina, Pará e Rio Grande do Sul, no Distrito Federal apenas um curso estava disponível, o qual se intitulava Atualização Atenção Álcool e Drogas, realizado pela UNB. (BRASIL, 2007).

Essa realidade mostra que a capacitação em Reforma Psiquiátrica ainda não é uma prioridade no DF e não está consolidada por meio de cursos de especialização específicos. Dessa forma, não há uma motivação intensa para que os profissionais participem de eventos que discutem essa temática.

Além de analisar a participação dos profissionais, a pesquisa colheu dados sobre o interesse dos mesmos em participar de cursos e eventos de capacitação em Reforma Psiquiátrica. Assim, obteve-se o seguinte gráfico, demonstrando que a maioria dos profissionais possui um grande interesse nesse tema: 
Gráfico VIII - Nível de interesse em conhecer a Reforma Psiquiátrica

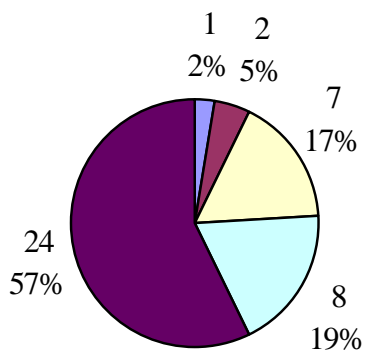

O nível mais alto de interesse foi marcado por 24 profissionais, representando 57\% do total; 8 pessoas (19\%) marcaram o nível 4; o nível 3 foi escolhido por 7 pessoas (17\%); os níveis 2 e 1 foram escolhidos, respectivamente, por 2 pessoas (5\%), e 1 pessoa (2\%).

Para estabelecer uma comparação entre o nível de participação, e o nível de interesse dos profissionais, os mesmos foram questionados sobre a carga horária disponível para participação em cursos de capacitação em Reforma Psiquiátrica:

\section{Gráfico IX - Disponibilidade de horas semanais para capacitação}

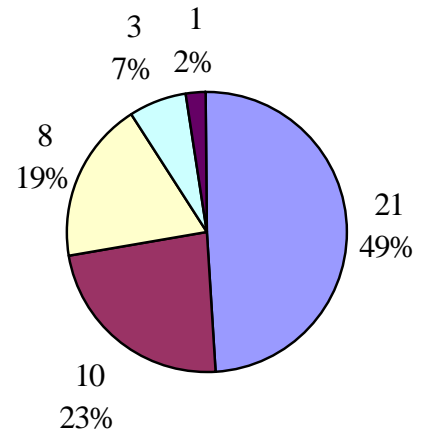

$\square$ De 1 a 2 horas

$\square$ De 2 a 3 horas

$\square$ De 3 a 4 horas

$\square$ Nenhuma

$\square$ Depende da chefia

$23 \%$

Os dados mostram que quase a metade dos profissionais (21, que corresponde a 49\% do total) dispõe somente de 1 a 2 horas semanais para participar de cursos desse tipo. 10 pessoas (23\%) responderam que poderiam dispor de 2 a 3 horas; 8 pessoas 
(19\%) marcaram a opção de 3 a 4 horas; 3 pessoas (7\%) disseram não ter nenhum tempo disponível para participar de um curso com esse tema; e 1 pessoa (2\%) afirmou que essa disponibilidade depende da chefia.

A indisponibilidade de tempo dos profissionais dos hospitais e instituições psiquiátricas para participar de eventos que tratam desse tema, muitas vezes, tem sido o empecilho para uma capacitação mais consolidada dos profissionais. Fagundes (1992) deixa clara essa dificuldade quando coloca que "a organização do trabalho [...] dificulta tanto a saída do serviço para a aprendizagem como a realização de atividades pedagógicas em horários e períodos não convencionais: férias e fins-de-semana” (FAGUNDES, 1992: 64).

Esses dados são referentes a todos os profissionais questionados. No entanto, nota-se que há uma diferenciação desses dados quando agrupados por categoria profissional, revelando a compatibilidade de algumas áreas com o modelo psicossocial de atendimento, além das relações de poder entre os saberes hegemônicos da instituição psiquiátrica. Fazendo-se uma média em relação ao nível de conhecimento que os profissionais de diversas áreas atribuíram a si mesmos foram obtidos os seguintes dados:

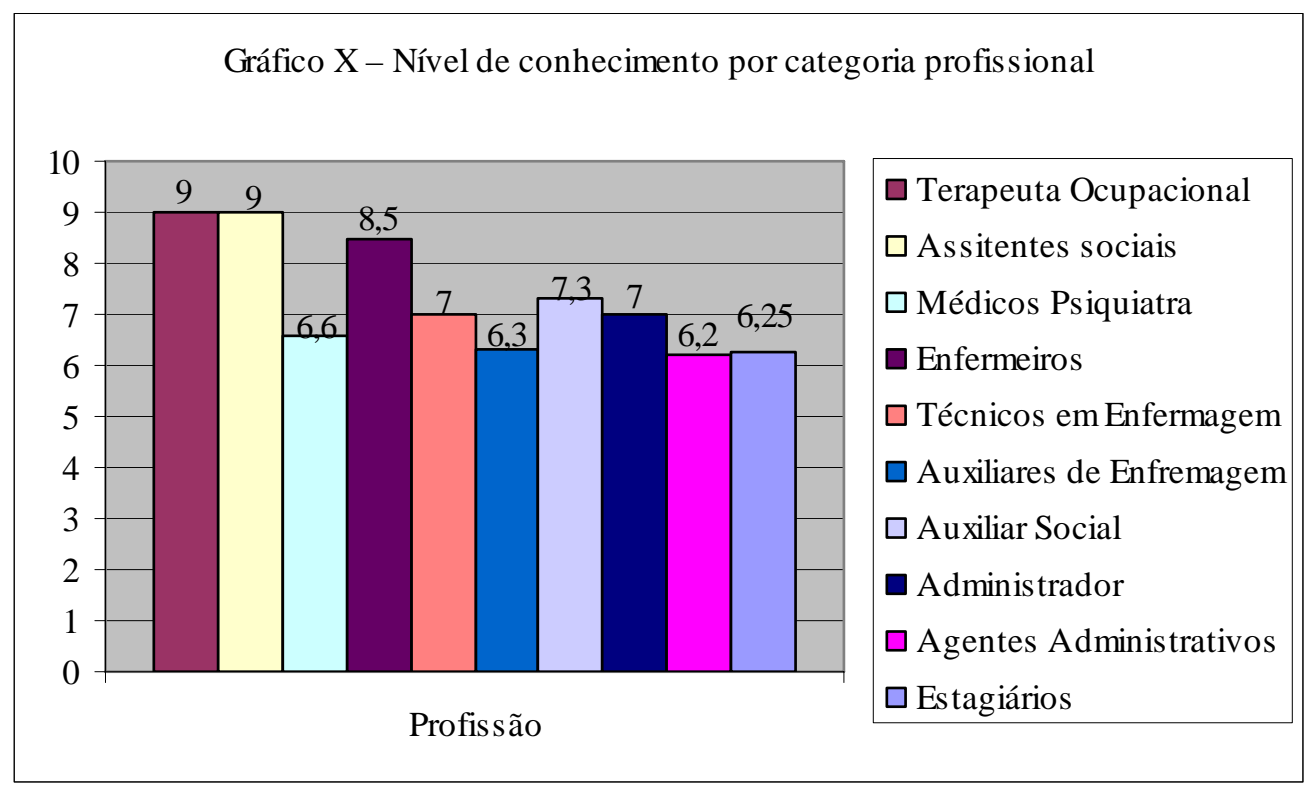

Observa-se que as áreas que se consideram mais bem informadas sobre a Reforma Psiquiátrica foram a Terapia Ocupacional e o Serviço Social, as quais 
marcaram o nível 9 de conhecimento. Isso se explica pelo fato de que, a primeira, carrega em si o paradigma da terapia como tratamento, muito além das funções do manicômio tradicional; e, o Serviço Social, por ser uma profissão que busca a garantia dos direitos dos cidadãos e a emancipação destes a partir da informação e do acesso aos processos de decisão. Em seguida, aparecem as enfermeiras, com o nível 8,5, o que pode ser explicado pela relação dessa profissão com a saúde mental, levantada no primeiro capítulo desse trabalho. Os médicos psiquiatras marcaram o nível 6,6 de conhecimento; os técnicos em Enfermagem, nível 7; auxiliares de enfermagem, nível 6,3; auxiliares sociais, nível 7,3; o administrador do hospital na época marcou o nível 7 de conhecimento, fato interessante, por fazer parte da direção de uma instituição psiquiátrica; os agentes administrativos tiveram uma média de 6,2 para seu nível de conhecimento; e, os estagiários, apontaram o nível de 6,25 de conhecimento, o que demonstra a falibilidade dos cursos superiores em estudar esse tema na academia, considerando que estes estavam se formando em Enfermagem, Psicologia, Serviço Social e técnico em Enfermagem.

O quadro seguinte resume esses dados a partir da auto-avaliação dos profissionais sobre seu conhecimento nesse tema:

\begin{tabular}{|l|l|}
\hline \multicolumn{2}{|c|}{$\begin{array}{r}\text { Quadro 2 - Auto-Avaliação do conhecimento dos } \\
\text { profissionais }\end{array}$} \\
\hline Profissão & Nível \\
\hline Terapeuta Ocupacional & Bom \\
\hline Assistentes sociais & Bom \\
\hline Médicos Psiquiatras & Regular \\
\hline Enfermeiras & Regular \\
\hline Técnicos em Enfermagem & Regular \\
\hline Auxiliares de Enfermagem & Regular \\
\hline Auxiliar Social & Regular \\
\hline Administrador & Regular \\
\hline Agentes Administrativos & Regular \\
\hline Estagiários & Regular \\
\hline
\end{tabular}

Como mostra o quadro 2, apenas as assistentes sociais e a terapeuta ocupacional afirmaram ter um conhecimento satisfatório sobre a Reforma Psiquiátrica.

A avaliação do interesse em conhecer a Reforma se faz muito importante por constatar que, em uma instituição psiquiátrica onde deveria ser cumprida a legislação 
sobre esse tema, apenas três das dez categorias profissionais questionadas mostraram ter o interesse máximo nessa questão.

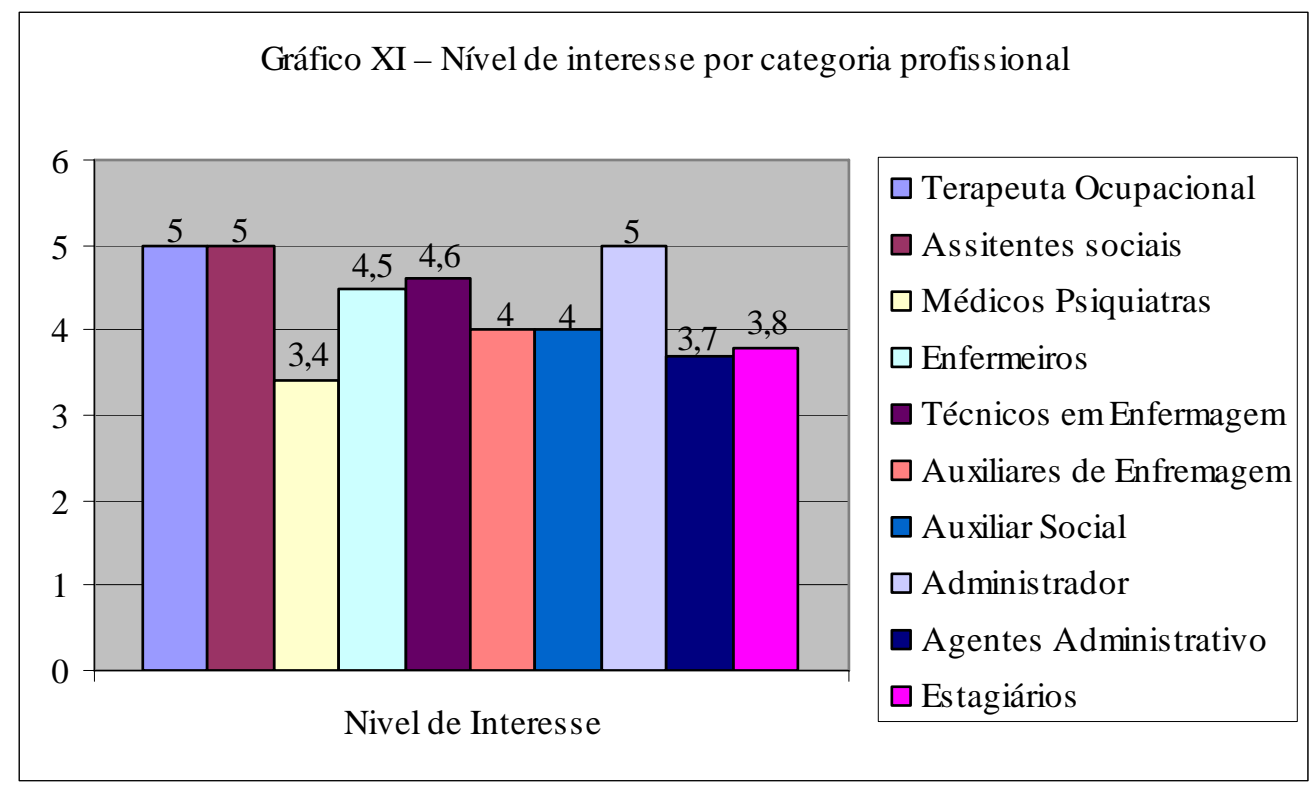

De acordo com o gráfico, a terapeuta ocupacional, as assistentes sociais e o administrador do hospital foram os únicos a marcar o nível máximo de interesse (5); os profissionais de enfermagem marcaram entre 4 e 4,6; a auxiliar social marcou o nível 4 de interesse; os agentes administrativos marcaram, em média, o nível 3,7; a média de interesse dos estagiários foi de 3,8, o que se pode explicar pela falta de motivação dentro da academia em conhecer e estudar esse tema; o nível mais baixo de interesse foi o dos médicos, que ficou em 3,4. Esse fato pode ser explicado pela característica da Reforma Psiquiátrica em superar o modelo centrado no hospital e no médico, retirando desse saber o controle total sobre o tratamento em saúde mental.

A participação em eventos e cursos de capacitação sobre a Reforma Psiquiátrica também foi avaliada de acordo com cada categoria profissional, coletando-se os dados esboçados no seguinte gráfico, considerando o resultado mostrado pelo gráfico VII, onde 25 pessoas (58\%) afirmaram ter participado de eventos desse tipo, e 18 pessoas (42\%) afirmaram nunca ter participado. 


\begin{tabular}{|l|l|l|l|}
\hline \multicolumn{5}{|c|}{ Gráfico XII - Participação em eventos por categoria profissional } \\
\hline \multicolumn{1}{|c|}{ Já participaram (sobre 25 pessoas) } \\
$\square$ Assitente social \\
$\square$ Auxiliar Social \\
$\square$ Enfermeiro \\
$\square$ Técnico em Enfermagem \\
$\square$ Auxiliar de Enfremagem \\
$\square$ Médico Psiquiatra \\
$\square$ Agente Administrativo \\
$\square$ Estagiários
\end{tabular}

A análise do gráfico permite perceber que, entre as categorias questionadas, aquelas em que todos os profissionais já haviam participado de eventos sobre a Reforma foram apenas quatro, cujos profissionais são a terapeuta ocupacional, as assistentes sociais, as enfermeiras e os auxiliares de Enfermagem. As outras áreas dividiram-se entre os que participaram desses eventos e os que nunca haviam participado. Dentre os primeiros estão: 2 auxiliares sociais (8\% do total de 25 pessoas); 8 técnicos em Enfermagem (32\%); 2 médicos psiquiatras (8\%); 2 agentes administrativos (8\%); e, 2 estagiárias (8\%). Os profissionais que nunca participaram são divididos em: 1 auxiliar social (6\% do total de 18 pessoas); 2 técnicos em Enfermagem (11\%); 3 médicos psiquiatras (17\%); o administrador do hospital na época (6\%); 5 agentes administrativos (28\%); e, 6 estagiários (32\%).

Esses dados sobre a participação dos profissionais em eventos sobre a Reforma revelam uma realidade importante para analisar a implementação dos serviços substitutivos dentro do HSVP. Em primeiro lugar, é interessante notar que o administrador do HSVP, na época, nunca havia participado desses eventos, revelando a pouca motivação da direção da época do hospital em conhecer a legislação e seus princípios. Em segundo lugar, os médicos psiquiatras, em sua maioria, nunca haviam participado, confirmando o baixo nível de interesse nesse tema, mostrado pelo gráfico XI. 
Em último lugar a grande maioria dos estagiários não havia participado de nenhum evento.

Considerando os cursos dos estagiários (Serviço Social, Psicologia, Enfermagem e Técnico em Enfermagem), pode-se afirmar que a capacitação neste tema precisa superar a barreira entre as universidades e os serviços de saúde mental pois, em geral, os cursos superiores da área da saúde não possuem disciplinas ou atividades específicas que preparem os estudantes para uma prática política de acordo com os princípios da Reforma. (FAGUNDES, 1992). No entanto, nota-se maior promoção e divulgação de eventos sobre essa temática na UNB, pelo curso de Psicologia.

\subsection{3- Serviços implementados por iniciativa de profissionais do HSVP}

No novo modelo de atenção à saúde mental, o hospital psiquiátrico é substituído por serviços que oferecem atenção integral à saúde, organizados de acordo com as necessidades apresentadas pela população. Entre esses serviços está a utilização de leitos psiquiátricos em hospitais gerais, serviços locais de atenção ambulatorial, residências públicas para abrigamento dos usuários crônicos sem referência familiar, centros de convivência nas comunidades, além de oficinas de trabalho e arte para promover a integração social e a expressão criativa dos usuários. (FAGUNDES, 1992).

De acordo com Fagundes (1992):

Tais serviços vão tecendo uma rede flexível e solidária de cuidados, de proteção, de emancipação, de atenção a diversas necessidades: educação, saúde, trabalho, lazer, afeto. Onde circulam diferentes trabalhadores: artistas, professores de educação física, recreacionistas, pedagogos, jornalistas, jardineiros, marceneiros, agricultores, além da equipe de saúde. Nesses serviços ocorrem a concretude da inter e transdisciplinaridade, da intersetorialidade, dos contratos sociais e terapêuticos. (FAGUNDES, 1992: $65)$.

A partir dessas afirmações e considerando o contexto de desestruturação da saúde mental no DF atualmente, essa parte da pesquisa busca conhecer quais os serviços que vêm sendo implementados pelos profissionais do HSVP, com a perspectiva de superar o modelo manicomial nos atendimentos. 


\subsubsection{1- Clube dos Amigos}

A partir do relato da assistente social do ambulatório do HSVP foi possível conhecer o Clube dos Amigos, o qual consiste num grupo de discussão de temas diversos coordenado por esta profissional.

O grupo foi criado em fevereiro de 2007 por iniciativa da assistente social, e é constituído por usuários do hospital e familiares, além de outras pessoas, pois é aberto a toda comunidade. De acordo com a assistente social, o número de participantes varia a cada encontro, mas permanece entre 30 e 40 pessoas. Os pacientes internados, em geral, não participam das reuniões, pois nas alas são realizadas atividades pela Terapia Ocupacional.

O Clube dos Amigos não tem documentação específica, pois não foi construída ainda pelos coordenadores, por indisponibilidade de tempo.

Os encontros ocorrem uma vez por semana, na quinta-feira, às dez horas da manhã, no Galpão Terapêutico ${ }^{18}$ do HSVP. Periodicamente são realizadas atividades na comunidade, como almoços, visitas culturais em exposições, entre outros.

Atualmente, o grupo conta apenas com a assistente social do ambulatório e a terapeuta ocupacional das Oficinas de Produção. Esporadicamente, participa das reuniões um médico psiquiatra, o qual, em 2007, esteve cinco vezes no grupo para esclarecer dúvidas de pacientes e familiares acerca das medicações e diagnósticos. A assistente social afirma que houve resistência de vários médicos para participar das reuniões do grupo, uma vez que todos foram convidados, mas apenas um se dispôs a participar.

Entre as dificuldades apontadas está a falta de recursos humanos e financeiros, pois não existe um fundo específico para realizar atividades com o grupo, e são apenas duas profissionais atuando nas reuniões, além das atividades cotidianas de cada uma em seus cargos. De acordo com a entrevistada, como o grupo foi criado por iniciativa da assistente social do ambulatório, e não pelo HSVP ou pela SES/DF, a participação dos profissionais é voluntária; assim, muitos são impedidos de ir às reuniões pelo

\footnotetext{
18 O Galpão Terapêutico foi criado em 2005 no hospital para ser um espaço de encontro entre a comunidade e os pacientes internados, através de atividades culturais. No entanto, está desativado para esse fim, pois está passando constantemente por várias reformas, sendo possível apenas o uso do espaço para reuniões de alguns grupos, como o Clube dos Amigos.
} 
cumprimento das suas atividades cotidianas; e outros, por não constituir parte integrante do seu papel no hospital, apenas não participam.

A assistente social aponta como resultados obtidos, principalmente, a interação entre usuários e familiares fora da instituição durante as saídas do grupo, a troca de informações e de vivências, e a promoção da autonomia dos usuários do ambulatório a partir do acesso às informações sobre suas patologias.

Para esta entrevista e a próxima não foi utilizado o instrumental construído para tais, pois, por incompatibilidade de horário, as mesmas foram realizadas fora do cronograma previsto. Consequentemente, não foram feitas algumas questões, como sobre a participação e conhecimento da profissional em relação à Reforma Psiquiátrica, tampouco sobre a avaliação de sua atuação.

\subsubsection{2- Time de Futebol Nacional Esporte Clube}

A mesma assistente social que coordena o Clube dos Amigos apresentou o Nacional Esporte Clube. Em maio deste ano foi criado esse time de futebol constituído por oito pacientes do ambulatório do hospital, coordenado pela assistente social e um paciente, que é o técnico do time. Assim como o Clube dos Amigos, o Nacional Esporte Clube ainda não tem documentação específica de criação e funcionamento.

Existe apenas um requisito para fazer parte do time: fazer uso de, pelo menos, um remédio controlado. Esse dado evidencia a centralidade da medicalização no tratamento oferecido no HSVP, reafirmando a manutenção do caráter manicomial em muitas práticas da instituição.

Os treinos ocorrem todas as quintas-feiras, na quadra de esportes do HSVP. Segundo a assistente social, essa estava inativa antes da criação do time.

A implementação dessa iniciativa esbarrou em uma dificuldade muito freqüente nos programas da saúde pública - os recursos financeiros. E, nesse caso, a inviabilidade do programa foi a falta de uma bola para os treinos e jogos.

Sem nenhum apoio do hospital, a bola foi obtida no Ministério dos Esportes. A assistente social conta que foi ao Ministério em seu carro particular, juntamente com os pacientes que montaram o time e, chegando lá, encontraram por acaso o ministro dos esportes, o qual, conhecendo a iniciativa, doou a bola para o Nacional Esporte Clube.

O nome do time foi escolhido após várias sugestões, como Haldol Esporte Clube, Carbamazepina Esporte Clube, Doidos por Bola, entre outros. No entanto, os 
jogadores preferiram tirar do nome do time o estigma da loucura que carregam, para ser considerado um time como qualquer outro.

\subsubsection{3- Oficinas de Produção}

As Oficinas de Produção são atividades desenvolvidas pelo Núcleo de Terapia Ocupacional, em salas do ambulatório do HSVP. A Terapia Ocupacional do HSVP foi criada por volta de 1992, pela equipe de enfermagem e uma médica que, na época, adotava os princípios de terapia para o tratamento. No início, a Terapia Ocupacional funcionava em uma pequena sala no prédio administrativo, onde, posteriormente, fundou-se o HDIA. Com o tempo, o trabalho foi crescendo e se transferiu para o ambulatório com uma nova perspectiva: não seria mais apenas terapia, mas produção.

A terapeuta ocupacional responsável pelas Oficinas atualmente afirma que, até onde conhece a história, na época de sua criação não houve apoio da SES/DF, mas a direção do hospital apoiou a iniciativa dos profissionais e tornou possível sua implementação.

Assim, foi dado o nome de Oficinas de Produção ao trabalho que, segundo a entrevistada, "objetiva a reinserção social e autonomia ao usuário de saúde mental, descobrindo as potencialidades e habilidades do sujeito" (informação verbal), pois, além de desenvolver atividades terapêuticas, os usuários aprendem a lidar com dinheiro e a melhorar suas relações interpessoais.

Embora já funcionem há vários anos, as Oficinas de Produção não têm um documento específico ainda; existe apenas o projeto inicial que foi reformulado com o passar do tempo e encontra-se em fase de reorganização pela equipe.

Atualmente, existem seis tipos de oficinas: Bijouteria, Trabalhos Manuais, Malharia, Serigrafia, Culinária e Tecelagem. Nestas são produzidos materiais pelos usuários do ambulatório do HSVP, os quais são expostos no bazar do hospital. As atividades ocorrem diariamente, de segunda a quinta, pois sexta-feira é dia de reunião da equipe. No entanto, os usuários freqüentam as Oficinas duas vezes na semana, intercaladamente.

A equipe é formada por uma terapeuta ocupacional, uma enfermeira, dois psicólogos, uma auxiliar de Serviço Social e 12 auxiliares de Enfermagem, os quais se dividem na coordenação das Oficinas. 
A direção atual apóia o trabalho das Oficinas, o que se afirma pela inclusão do Núcleo de Terapia Ocupacional no organograma do HSVP, em julho de 2007. Segundo a entrevistada, a questão do apoio “depende muito da visão do profissional que está gerenciando" (informação verbal); inclusive a relação com outros profissionais. Atualmente, a entrevistada considera que a terapia ocupacional conquistou espaço, pois "alguns profissionais encaminham para avaliação, mas ainda temos resistências" (informação verbal).

Entre as dificuldades apontadas pela entrevistada está a escassez de recursos humanos, materiais e verbas por parte da SES/DF, além da falta de estratégias de inserção no mercado de trabalho ou em outros tipos de atividades, o que possibilitaria maior emancipação dos usuários. Mesmo assim, o trabalho desenvolvido tem apresentado resultados satisfatórios, pois as internações têm diminuído, tem sido possível descobrir novas capacidades, habilidades, talentos e potencialidades dos usuários, além da promoção de autonomia dos mesmos.

Em relação à Reforma Psiquiátrica, a entrevistada afirma conhecer bem o assunto, inclusive informando que a lei “atualmente está sendo discutida no plenário da câmara federal, que infelizmente tem suas falhas, pois quem não a conhece direito, critica” (informação verbal). De acordo com ela, para que a Reforma possa acontecer, é preciso mais apoio do governo e parcerias com a sociedade.

A profissional reconhece seu trabalho como uma alternativa ao modelo manicomial, mas afirma que, para que possa desenvolvê-lo com êxito são necessárias parcerias, e também “a compreensão da população sobre o trabalho da Terapia Ocupacional, que visa o retorno do paciente ao trabalho, podendo ser através de cooperativas ou geração de renda" (informação verbal).

\section{Oficina de Serigrafia}

Durante a pesquisa, foi possível conversar com uma técnica de enfermagem do Núcleo de Terapia Ocupacional, a qual coordena, juntamente com outra técnica de enfermagem, a Oficina de Serigrafia, parte do trabalho das Oficinas de Produção.

De acordo com a entrevistada, a Oficina de Serigrafia, além da produção de camisetas, também trabalha com tapetes, tendo em vista o alto custo dos materiais específicos de serigrafia. Durante as atividades é possível observar as características do 
paciente, quanto à higiene, ao uso e efeito da medicação, entre outros aspectos. Ela afirma que o trabalho na Oficina possibilita a diminuição das internações e o controle da medicação, pois é criado um vínculo tanto entre profissional-paciente, quanto entre os pacientes, em que um incentiva o outro a aderir ao tratamento. Além disso, são realizadas parcerias, a fim de conseguir acesso a serviços, como o caso de terem conseguido tratamento dentário para um paciente.

Os profissionais que atuam na Oficina são duas técnicas de enfermagem, que coordenam o trabalho, além das duas psicólogas e a auxiliar social da equipe em geral, e a assistente social do ambulatório, que oferece atendimento aos pacientes encaminhados. A profissional afirma que há um médico psiquiatra do ambulatório que atende os pacientes das oficinas, quando são observados pelas técnicas de enfermagem efeitos colaterais da medicação, necessidade de alteração dessa, entre outros aspectos; no entanto, afirma que se não houvesse o apoio desse médico, "seriam muitos não na cara" (informação verbal), ao solicitar revisão do tratamento de algum usuário da Oficina aos outros psiquiatras do Ambulatório.

A entrevistada tem participado de eventos que tratam sobre a Reforma Psiquiátrica, com ênfase em um fórum sobre alcoolismo e saúde mental realizado recentemente, e percebe sua atuação como uma alternativa ao modelo manicomial, pela promoção da autonomia dos usuários. Inclusive, tem uma proposta de iniciar no HSVP um espaço de exposição de artes, aprofundando a proposta do artesanato das Oficinas para artes, pois é estudante de Artes Plásticas na Universidade de Brasília (UNB).

\subsubsection{4- Setor Terapêutico Ocupacional - Internação}

A pesquisa desse serviço foi feita a partir de análise documental do Plano de Atuação Terapêutica nos Serviços de Internação do HSVP, dos documentos que estabelecem as Rotinas Terapêuticas, além da descrição dos Grupos Terapêuticos, e entrevista com a terapeuta ocupacional responsável.

No meio das alas de internação do HSVP funciona o Setor Terapêutico Ocupacional, coordenado por uma terapeuta ocupacional, o qual tem como objetivo “organizar programação terapêutica para os pacientes das unidades de internação do HSVP, com integralidade às ações médicas e sociais.” (MALCHER: 1).

A entrevistada relata que quando chegou à internação do HSVP, em 2002, não havia no hospital, há mais de 10 anos, atividades terapêuticas destinadas aos pacientes 
que permaneciam internados nas alas. Então, propôs a realização de um trabalho que agregasse profissionais de várias áreas para criar espaços terapêuticos dentro da internação.

Essa proposta foi bem aceita entre os profissionais e a direção do hospital que, na época, de acordo com a terapeuta ocupacional, estava aberta às mudanças que deveriam acontecer no modelo de atendimento do hospital. Dessa forma, em 2003 foi criado este setor, o qual, de acordo com um documento do mesmo, datado de fevereiro de 2004, tem como função a realização do acolhimento individual ou em grupo dos pacientes internados, objetivando: a) a criação de vínculo terapêutico; b) envolvimento dos pacientes nas atividades terapêuticas; e, c) o conhecimento da história de vida e da doença do paciente. Além disso, esse setor foi responsabilizado por estabelecer e acompanhar o desenvolvimento de uma rotina terapêutica para os pacientes, desenvolver grupos semanais com esses e seus familiares, e promover uma semanal para a equipe profissional. (HSVP, 2004).

O trabalho do setor, então, foi organizado a partir do Plano de Atuação Terapêutica nos Serviços de Internação do HSVP, escrito pela terapeuta ocupacional entrevistada. Neste plano é colocado que “a abordagem terapêutica é um importante coadjuvante do tratamento médico.” (MALCHER: 1). De acordo com este documento, o paciente internado e do Pronto Socorro deve ter, durante sua estadia no hospital, acesso às informações sobre seu transtorno ou doença, acompanhamento médico e tratamento com medicamentos, suporte social, familiar e suporte terapêutico. A proposta era que a participação dos pacientes em uma rotina terapêutica durante sua internação favoreceria o seu relacionamento interpessoal, além de trabalhar sua autoestima, auto-imagem, e reestruturar dos hábitos e rotinas diárias.

Conforme estabelece o Plano de Atuação Terapêutica nos Serviços de Internação do HSVP, as atividades seriam assim divididas: 


\begin{tabular}{|c|c|c|}
\hline \multicolumn{3}{|c|}{$\begin{array}{c}\text { Quadro 3: Atuação das equipes do Setor de Terapia Ocupacional da Internação } \\
\text { dividido por atividades. }\end{array}$} \\
\hline ATUAÇÕES & EQUIPE & ATIVIDADES \\
\hline $\begin{array}{l}\text { Rotina de Atividades } \\
\text { Terapêuticas }\end{array}$ & $\begin{array}{l}\text { Auxiliares de Enfermagem } \\
\text { e/ou padioleiro, terapeuta } \\
\text { ocupacional (equipe fixa). }\end{array}$ & $\begin{array}{c}\text { Oficinas expressivas, auto } \\
\text { cuidado, atividades sócio- } \\
\text { recreativas etc... }\end{array}$ \\
\hline Grupo terapêutico & $\begin{array}{l}\text { Serviço Social, Residentes, } \\
\text { Terapeuta ocupacional }\end{array}$ & $\begin{array}{c}\text { Grupo Medicação, Grupo } \\
\text { Família, Grupo } \\
\text { Motivacional, Grupo } \\
\text { específico. }\end{array}$ \\
\hline Atividades lúdicas & Voluntários & Teatro, dança, etc. \\
\hline
\end{tabular}

Fonte: Plano de Atuação Terapêutica nos Serviços de Internação do HSVP, 2004.

A terapeuta ocupacional apresentou documentação de alguns grupos criados dentro do Setor de Terapia Ocupacional, os quais são:

- Grupo de Acolhimento: este grupo tinha como objetivo melhorar a receptividade do usuário pela internação e tratamento, estimulando entre os profissionais uma consciência crítica sobre o tratamento e a rotina e normatização das unidades do hospital, através da realização de reuniões semanais de, aproximadamente, uma hora e meia. Este grupo deveria ser constituído por residentes, terapeuta ocupacional, profissionais de Enfermagem, Serviço Social e Nutrição.

- Grupo Terapêutico de Pacientes: através de reuniões semanais de, aproximadamente, uma hora e meia, esse grupo pretendia criar interação terapêutica entre técnicos e pacientes para melhoria na evolução e tratamento do último. Antes e depois do grupo, a equipe, constituída de residentes e uma terapeuta ocupacional, deveria se reunir para discutir a organização do grupo e os papéis de cada profissional na reunião.

- Grupo Terapêutico de Família: contando com uma equipe interdisciplinar formada por residentes, terapeuta ocupacional e assistente social, esse grupo pretendia interagir com a família dos pacientes internados a fim de esclarecer dúvidas sobre o tratamento dos mesmos, visando também à criação de vínculos entre os familiares e a instituição. As reuniões deveriam acontecer semanalmente, com duração de, aproximadamente, uma hora e meia.

- Grupo Oficina de Expressão Corporal: através de uma programação que incluía brincadeiras corporais, danças, representação corporal e verbal e apresentações em datas festivas, esse grupo pretendia possibilitar a expressão de sentimentos, a reconstrução da auto-estima e a organização das funções mentais em torno do corpo, 
estimulando, ao mesmo tempo, as relações interpessoais e a convivência dos pacientes. Por meio de atividades de lazer realizadas semanalmente por, aproximadamente, uma hora e meia, seria possível melhorar a qualidade de vida dos pacientes, além de possibilitar a participação desses em apresentações durante atividades culturais desenvolvidas no hospital.

- Grupo de Música: este grupo pretendia trabalhar a auto-estima dos pacientes e criar vínculos interpessoais, através da música. As atividades, realizadas semanalmente por, aproximadamente, uma hora e meia, variavam desde a confecção dos instrumentos musicais com sucata, até a criação de pastas com letras de músicas e a organização e preparação de apresentações para datas festivas. O objetivo era promover a comunicação, a aprendizagem, a expressão e a organização através de atividades culturais.

Embora o serviço da terapia ocupacional estivesse bem organizado por meio da divisão dos grupos, atualmente, o trabalho encontra-se desestruturado. De acordo com a entrevistada, isso é resultado de vários fatores. Por um lado, houve a mudança da direção do hospital, a qual estabeleceu novas diretrizes para a terapia ocupacional do hospital em geral, centralizando os serviços em um núcleo único. Dessa forma, o Setor de Terapia Ocupacional da internação, que antes era independente, agora está subordinado ao Núcleo de Terapia Ocupacional do hospital. Além disso, atualmente a parte de emergência encontra-se em reforma, e os pacientes que ingressam no HSVP pelo Pronto-Socorro acabam sendo colocados nas alas de internação, causando superlotação das alas e, consequentemente, das salas onde aconteciam várias das atividades previstas.

A equipe de Terapia Ocupacional da internação também está bem reduzida. Atualmente é constituída apenas pela terapeuta ocupacional, quatro técnicos em Enfermagem, e estagiários de Psicologia que desenvolvem atividades com os internos, no entanto, sem continuidade.

Mesmo assim, ainda estão sendo desenvolvidas algumas atividades, visando principalmente, à elevação da auto-estima, à valorização da auto-imagem e ao desenvolvimento cognitivo. Para isso, semanalmente ocorrem algumas atividades, como o Auto-Cuidado, desenvolvido pelos técnicos de Enfermagem, um dia com os homens, e 
outro com as mulheres, onde são estimulados os cuidados com o corpo e a higiene pessoal.

As demais atividades são desenvolvidas em dias da semana específicos. Na segunda-feira à tarde, é apresentado um filme, ou são oferecidos livros para leitura e materiais para desenho. Sexta-feira é dia de passeio, quando os pacientes internados recebem roupas e sapatos diferentes do traje do hospital, e são levados a exposições, ao circo, ao cinema, ao Parque da Cidade, ao Jardim Zoológico, ao Parque Água Mineral, à Feira do Livro, entre outros eventos culturais. Nessas ocasiões, há a distribuição de lanche para os pacientes, os quais são estimulados a dividir com os demais, gerando maior interação e convivência no grupo.

As roupas utilizadas para os passeios, bem como nas apresentações desenvolvidas para datas festivas, em geral, são resultado de doações. Entre elas, há também vestimentas caipiras, utilizadas nas festas juninas realizadas todos os anos pelo hospital, ocasião em que pacientes e profissionais dançam juntos.

De acordo com a terapeuta ocupacional, a cultura do setor na internação é justamente essa: a participação do paciente no cotidiano da instituição, compartilhando com os profissionais suas habilidades e criatividade, como a ajuda na confecção de cartazes sobre eventos no hospital, a construção dos materiais de trabalho nesses eventos, além da ajuda na arrumação das salas, entre outras atividades. No momento da entrevista, pôde-se observar essa participação dos pacientes, pois logo após o término da atividade de Auto-Cuidado com as mulheres, desenvolvido por uma técnica em Enfermagem, um dos pacientes, por iniciativa própria, foi ajudar a profissional a recolher os materiais e organizar a sala.

Com isso, embora o trabalho não esteja ocorrendo na sua totalidade, a terapeuta ocupacional ressalta como resultados o estímulo à afetividade e criação de vínculos, tanto entre os pacientes, como com a equipe profissional, além de o setor servir como referência de escuta e imposição de limites às vontades dos internos.

Com relação ao seu conhecimento acerca da legislação da Reforma Psiquiátrica, a terapeuta ocupacional entrevistada julga satisfatório, pois todos os anos participa da Semana de Luta Antimanicomial (semana do 18 de maio), e também da organização de eventos que chamem a atenção da sociedade sobre essa causa. Este ano, participou dos eventos da referida semana, que aconteceram na Rodoviária do Plano Piloto e na Praça 
do Relógio, em Taguatinga. Nestes eventos, a profissional sempre tentar envolver os usuários. Atualmente, está iniciando um curso de especialização em Saúde Mental pela UnB, e acredita que este curso possibilitará um melhor desenvolvimento da Reforma Psiquiátrica no DF.

Apesar disso, a terapeuta ocupacional não acredita que seu trabalho possibilite a implementação da Reforma Psiquiátrica no âmbito do HSVP, pois, segundo ela, "o cartão de visita do HSVP deveria ser o ambulatório e serviços que estimulassem uma autonomia na sua realidade social” (informação verbal). Para ela, a internação deveria ser apenas um "recurso de suporte", e, por isso, a terapia ocupacional da internação ainda é pouco desenvolvida, pois está submetida à abordagem médica hospitalocêntrica oferecida pelas técnicas da internação.

\subsubsection{5- Grupo de Atendimento Pós-Internação (GAPI)}

O Grupo de Atendimento Pós-Internação (GAPI) é um serviço novo no hospital; foi implantado em maio de 2007. A idéia surgiu pela observação da equipe de Enfermagem da internação e da emergência, a qual constatou que os pacientes tinham um retorno rápido à internação, depois de receber alta; por exemplo, o paciente ficava internado durante 15 dias, e, após 5 ou 6 dias de alta, era levado novamente pela família ao hospital em situação de crise. Dessa forma, tornou-se necessário conhecer as causas pelas quais os pacientes entravam em crise novamente quando estavam em casa; assim, foi criado o GAPI, com o objetivo de acompanhar o paciente e sua família no período pós-alta.

Entre os membros da equipe de Enfermagem referida, foi escolhida a enfermeira entrevistada para chefiar o programa, o qual teve sua criação publicada no Diário Oficial; porém, não foi possível acessar este documento durante a pesquisa. A direção do hospital apoiou a criação do GAPI, inclusive tendo o diretor do HSVP acrescentado algumas idéias ao projeto inicial.

O GAPI possui uma sala no prédio da administração do hospital, de onde cumpre várias de suas atribuições. O trabalho do Grupo funciona da seguinte forma: todos os dias um membro da equipe vai até a Unidade de Internação do HSVP e colhe os dados pessoais de todos os pacientes aos quais foi dada alta naquele dia. Dois ou três dias depois, é feito um contato com a família dos mesmos para saber como estão, se aderiram ao tratamento, se estão dormindo e se alimentando adequadamente, se estão 
tomando a medicação corretamente, e como está a família. De acordo com a resposta do familiar, o mesmo é orientado quanto a estratégias para administrar a medicação, entre outras medidas.

A entrevistada disse que esse contato por telefone tem tido uma resposta muito positiva das famílias, pois acaba sendo um momento de desabafo, de pedido de ajuda para as mesmas, além de se sentirem acolhidas pelo acompanhamento oferecido pelo GAPI.

Muitas vezes, o GAPI, nesse contato com a família, encaminha-a ao Grupo de Terapia Comunitária (serviço do qual se tratará em seguida), ou para acompanhamento psicológico do ambulatório. Até hoje só foi possível promover uma reunião de família especifica do GAPI, pela quantidade de trabalho diário. No entanto, a enfermeira afirma que os outros serviços do HSVP têm suprido essa necessidade.

Além desse trabalho, o GAPI se responsabilizou pelo cadastro de todos os pacientes que recebem alta, os quais são agrupados em gráficos por cidades, sexo, idade, patologias, entre outros aspectos, gerando uma base de dados importante para o HSVP. Esses dados têm sido de grande importância para a proposta do GAPI de formar redes de atenção à saúde mental com os Centros de Saúde das cidades satélites, e com os CAPS, onde já estão implantados, o que possibilitaria o desafogamento do HSVP.

Este trabalho em rede tem acontecido de forma satisfatória em algumas cidades do DF, através da participação da Equipe Matricial do Ministério da Saúde. De acordo com a entrevistada, a Equipe Matricial é uma iniciativa do Programa Saúde da Família (PSF), e, no caso do HSVP, a enfermeira responsável por esta equipe faz um contato com a enfermeira do GAPI e colhe dados dos pacientes em alta de acordo com as cidades. Esses, então, são encaminhados aos Centros de Saúde ou CAPS para serem acompanhados em sua própria cidade. O GAPI fornece relatórios sobre os pacientes aos médicos das cidades satélites que os atenderão, com vistas a mudar o modelo centralizador do HSVP.

Atualmente, já estão formadas redes de forma efetiva nas cidades de Águas Lindas (Goiás), São Sebastião, Paranoá, Recanto das Emas, Sobradinho, Planaltina e Brazlândia.

A equipe do GAPI é composta pela enfermeira e dois técnicos em Enfermagem; segundo a entrevistada, não há necessidade de incorporação de novos profissionais, pois 
o trabalho integrad-se aos outros serviços do HSVP. Segundo ela, há um bom relacionamento com as outras áreas do hospital, como a Psicologia, o Serviço Social, a Terapia Comunitária, e recebe muita ajuda da direção; no entanto, tem encontrado dificuldades na relação com os médicos, que, segundo ela, "se acham os reis”, pois apenas um dos psiquiatras do ambulatório se dispôs a auxiliar no processo de remarcação de consultas dos pacientes atendidos pelo GAPI. De acordo com a enfermeira, pela via normal de marcação de consultas do ambulatório, seria impossível manter o acompanhamento proposto pelo GAPI, pois as mesmas têm sido marcadas para meses após a demanda.

Essa é uma das dificuldades para o desenvolvimento do trabalho: a marcação de consultas no ambulatório. Mas a enfermeira disse que já existem alguns profissionais do hospital fazendo parcerias com o GAPI, como a equipe do ambulatório imediato e de suicídio, atendendo aqueles pacientes que, constatado pelo GAPI, reincidem na crise num curto espaço de tempo.

Outra dificuldade apontada é a falta de abertura de novos serviços de saúde mental, como os CAPS, que possibilitariam uma maior articulação em redes.

A entrevistada afirma conhecer bem a proposta da Reforma Psiquiátrica; inclusive, recentemente, participou de um curso de 60 horas sobre a Reforma, promovido pela Fundação Oswaldo Cruz. Ela percebe que sua intervenção possibilita a implementação da Reforma no âmbito do HSVP, pois evita a reinternação, promovendo a mudança do modelo hospitalocêntrico através da desospitalização.

\subsubsection{6- Grupo de Terapia Comunitária}

O conhecimento desse serviço deu-se a partir de entrevista com a enfermeira responsável por sua criação e execução, pois não há ainda documentação específica sobre o mesmo.

Este grupo foi criado há apenas quatro meses no HSVP pela enfermeira que está lotada no Programa Vida em Casa, o qual oferece atendimento domiciliar aos pacientes. No entanto, o Grupo de Terapia Comunitária não está vinculado ao mesmo. Este foi criado a partir da participação da enfermeira no Curso de Terapia Comunitária, realizado pela Universidade do Ceará, o qual ainda está em andamento.

De acordo com a enfermeira, há aproximadamente oito anos, a direção do hospital buscou transformar o HSVP em um CAPS, sob a perspectiva do modelo 
psicossocial de atenção à saúde mental. ${ }^{19}$ Nessa época, a enfermeira entrevistada fazia parte da equipe do HDIA, o qual estava bem estruturado.

Com a diminuição desta equipe na direção seguinte, a enfermeira voltou a atuar na emergência, onde vários pacientes que, antigamente eram atendidos pelo HDIA, cobravam dela o desenvolvimento de atividades terapêuticas como as desenvolvidas por aquele serviço. A enfermeira afirma que, quando o HDIA estava bem estruturado, os pacientes que dele participavam diminuíram se índice de internação; mas quando este teve seu atendimento restringido, muitos voltaram a ter crises com mais freqüência.

Dessa forma, inspirada pela proposta da Terapia Comunitária, a qual busca responder às demandas dos indivíduos a partir de soluções imediatas presentes na comunidade, a enfermeira, juntamente com outra enfermeira, uma psicóloga, e uma voluntária, todas atuantes no CAPS de Taguatinga Sul, formaram o Grupo de Terapia Comunitária, que funciona tanto neste CAPS, como no HSVP.

Sua proposta é de promover terapia em grupo aberta à comunidade; no entanto, tem como principais participantes os familiares de pacientes internados, pacientes que receberam alta recentemente e pacientes e familiares atendidos pelo Programa Vida em Casa ou encaminhados pelo ambulatório ou pelo GAPI.

O número de participantes varia a cada reunião, pois como são buscadas respostas imediatas às questões dos participantes, muitos não retornam após terem resolvido seus problemas. As reuniões ocorrem no Galpão Terapêutico todas as quartas-feiras, às 14 horas.

A enfermeira afirma que recebeu apoio da direção para a criação do grupo, e que muitos profissionais do HSVP já participaram do grupo, mas não mantêm freqüência por conta da falta de tempo livre para esta atividade.

Em relação à Reforma Psiquiátrica, a enfermeira afirma que conhece bem os princípios e diretrizes do novo modelo proposto pela legislação, pois, desde o tempo em que atuava no HDIA, já tinha uma atuação baseada na perspectiva de transformação do modelo manicomial vigente no HSVP. Já participou de vários eventos que tratam desse tema, inclusive como palestrante, como os Encontros de Psiquiatria que acontecem todos os anos no hospital, promovidos pelos próprios profissionais e grupos de saúde mental da UNB.

\footnotetext{
${ }^{19}$ Este fato foi apontado anteriormente no Capítulo 2, onde trata sobre o Hospital São Vicente de Paulo.
} 
A profissional reconhece sua intervenção como uma alternativa ao modelo manicomial, pois está pautado pelos princípios da Reforma Psiquiátrica, uma vez que a Terapia Comunitária se baseia na descentralização do poder médico sobre a saúde mental, transferindo o poder de voz, transformação e tratamento à comunidade.

\subsubsection{7- $\quad$ Programa Vida em Casa (PVC)}

O conhecimento desse Programa deu-se a partir da análise dos documentos de criação (Portaria nº. 86, de 28 de junho de 2004), estabelecimento de diretrizes, (Projeto Vida em Casa: Programa de Saúde Mental Domiciliar, 2004), folder do Programa, além de entrevista com a assistente social responsável pelo mesmo e a própria experiência da pesquisadora, por ter sido seu campo de estágio durante um ano.

A idéia do Programa surgiu a partir do fechamento da Clínica de Repouso Planalto. Nessa época, a assistente social que o criou havia saído do HBDF, onde chefiava a Unidade de Psiquiatria. No entanto, foi convidada para participar da comissão de fechamento da referida clínica e, no caminho, conversou com o diretor do HSVP. Nessa conversa, a assistente social apontou a necessidade de se criar um serviço de atendimento aos pacientes que estavam saindo dessa instituição, após longos anos de internação, os quais deveriam ser atendidos no domicílio. O diretor aprovou a idéia e, posteriormente, perguntou se havia alguma restrição para que a assistente social fosse trabalhar no HSVP, implantando este Programa.

A assistente social, aceitando a proposta, foi convocada pelo diretor para implantar o programa de atendimento aos pacientes no domicilio, no âmbito do HSVP. Houve muito apoio da direção na época, tanto que o diretor se dispôs a providenciar o necessário para seu funcionamento. A entrevistada, então, pediu apenas uma sala com telefone, e a disposição de um carro para visitas. A equipe foi montada pela assistente social, de acordo com o perfil traçado pela mesma.

Vários fatores contribuíram para o fortalecimento do PVC. Um deles foi a criação, em 08 de maio de 2003, da Bolsa “De Volta Para Casa”, já citado em tópico anterior, motivando ainda mais a desospitalização; o PVC possibilitou que os usuários dos serviços de saúde mental de Brasília fossem beneficiados com a bolsa, através do pleito da assistente social, pois esses pacientes não tinham dois anos de internação ininterrupta, pela característica própria das instituições de Brasília. Atualmente, 370 
pacientes no DF recebem o benefício, e a assistente social entrevistada tornou-se referência da bolsa no DF.

Além disso, no início do funcionamento do PVC, a Residência Médica foi inserida no Programa, possibilitando atendimentos interdisciplinares.

O principal objetivo do PVC, em sua criação, era desenvolver os princípios da Reforma Psiquiátrica, da Política Nacional de Saúde Mental e do SUS, visando integrar a pessoa acometida por transtorno mental à vida comunitária.

Assim, o Programa Vida em Casa (Programa de Assistência Domiciliar a Pacientes Mentais Crônicos, como descrito em seu documento de criação) foi instituído por meio da Portaria $n^{\circ} .86$, de 28 de junho de 2004, com o objetivo de estabelecer, no âmbito da SES/DF, a modalidade de Assistência Domiciliar, tendo nela inclusos procedimentos médicos, de Enfermagem, fisioterapêuticos, nutricionais, psicológicos, e a assistência social, entre outros, necessários ao cuidado integral do paciente em domicílio. Essa mesma portaria estabeleceu que a Assistência Domiciliar só poderia ser realizada por indicação médica, com expressa concordância do paciente e/ou de sua família, por meio de equipes multidisciplinares que atuariam de forma preventiva, terapêutica e reabilitadora. O Programa foi criado para, implantado gradualmente, abranger todo o DF.

A análise documental do Programa mostra que sua proposta de implementação tem como objetivo atender pessoas acometidas por transtorno mental grave com índice de internações prolongadas e resistentes ao tratamento, propiciando suporte social, estimulando o fortalecimento dos laços familiares, no intuito de promover a desinstitucionalização e viabilizar a (re)inserção social. O folder do programa estabelece como objetivos a inclusão social dos usuários atendidos a partir de uma atuação profissional multidisciplinar em domicilio, com vistas à melhoria da qualidade de vida dos usuários, inserindo-os na vida comunitária e familiar. (HSVP, 2007).

Essa proposta aponta para as diretrizes estabelecidas pela Reforma Psiquiátrica, pois defende a substituição da estrutura manicomial por um tratamento aberto, ressocializante e interativo com a comunidade.

O público-alvo do PVC é formado por pacientes crônicos, com mais de dois anos de diagnostico do transtorno ou doença mental, com dificuldades de adesão ao tratamento, e também deficientes mentais e idosos com transtorno mental com 
dificuldades de locomoção. Atualmente são atendidos cerca de 370 pacientes no Programa.

O PVC tem como objetivos específicos: a) prevenir crises, recaídas e reinternações prolongadas dos usuários assistidos; b) desenvolver ações de promoção, proteção e recuperação da saúde mental dos usuários e familiares, articulado a redes sociais; c) inserir a família no processo terapêutico do paciente, com vistas à adesão ao tratamento; d) promover a inclusão social do paciente e a família na comunidade, desmistificando o estigma da doença mental; e) diminuir o número de reinternações psiquiátricas no DF e, com ela, os custos advindos de internações repetidas e longas; f) diminuir o volume excedente de atendimentos nos serviços de emergência psiquiátrica; g) realizar o tratamento medicamentoso de acordo com a necessidade clínica do paciente, incluindo medicação de alto custo; e, h) promover assistência psicológica de apoio a pacientes, familiares ou cuidadores.

Atualmente, a equipe do PVC é composta por uma enfermeira; seis técnicos de enfermagem; duas psicólogas, sendo uma exclusiva e a outra, com carga de 8 horas semanais; duas médicas psiquiatras, uma com carga de 12 horas, e a outra, com 8 horas; duas estagiárias de Serviço Social; e quatro estagiárias de Psicologia.

Por ser reconhecido não só no HSVP, mas como uma referência em saúde mental no DF, a relação com os profissionais de outras áreas do hospital tem sido satisfatória; foi citado como exemplo pela entrevistada o encaminhamento de pacientes ao Programa pelos médicos do ambulatório.

Os resultados do Programa têm se mostrado positivos, uma vez que a grande maioria dos pacientes reintegrou-se totalmente à família e tem sido atendida em casa, com o acompanhamento psicossocial e medicamentoso. A entrevistada afirma que $99 \%$ dos pacientes atendidos estão estáveis e sem necessidade de internação.

Para cumprir seus objetivos, recentemente o PVC começou a traçar algumas estratégias, que, de acordo com a entrevistada, foram resultado do aprendizado no cotidiano da atuação profissional. Exemplo disso é a articulação feita com a Unidade de Internação, quando da internação dos pacientes vinculados ao PVC, para que sejam atendidos pelas médicas do Programa, pois essas já têm um vínculo com os pacientes. Esses também são visitados pela equipe do PVC nas alas de internação, fortalecendo a idéia do acompanhamento, facilitando a adesão ao tratamento. 
Outro avanço alcançado com o trabalho do PVC foi a relação com o Instituto Nacional do Seguro Social (INSS) com relação à interdição judicial. Para a concessão do Beneficio de Prestação Continuada $(B P C)^{20}$, os peritos do INSS exigiam que a pessoa com transtorno mental fosse interditada, ou seja, tivesse um curador que respondesse por seus direitos civis. Assim, o HSVP pedia a interdição através de um laudo médico constando o número correspondente ao Código Internacional de Doenças e declarando a incapacidade do sujeito. No entanto, o PVC lançou uma estratégia em que, agora, não é mais expedido um laudo médico pedindo a interdição, mas sim um laudo médico psicossocial, constando toda a história do paciente e suas internações, conseguindo a concessão do beneficio sem que seja exigida a interdição judicial, garantindo o exercício dos direitos civis dos usuários.

Em nível interno ao PVC, os avanços dizem respeito à participação dos profissionais, recentemente, em um curso de visita domiciliar e de terapia comunitária, capacitando a equipe para a execução do trabalho. Além disso, a equipe de Enfermagem assumiu o Programa com relação à medicação e atendimento, e as questões sociais estão sendo resolvidas pelas estagiárias de Serviço Social. A Psicologia tem trabalhado com grupos de família.

A maior dificuldade apontada pela entrevistada é a falta de um carro para visitas, pois, a van que pertencia ao PVC foi emprestada em janeiro deste ano à Vigilância Sanitária da SES/DF e nunca mais devolvida, dificultando o trabalho do Programa, pois, nem sempre há um carro disponível para realizar as visitas domiciliares e, quando há, a equipe não pode ir completa à visita, pois os carros não comportam a quantidade de pessoas. No entanto, a assistente social aponta o apoio da direção e da equipe do transporte com relação à prioridade concedida ao Programa na concessão de carros para visitas.

Outra perda, segundo a assistente social, foi a extinção da Residência Médica do PVC, pois limitou o atendimento médico à carga horária cumprida pelas psiquiatras, que é escassa.

\footnotetext{
${ }^{20}$ O Benefício de Prestação Continuada consiste no pagamento de um salário mínimo pago à pessoa portadora de deficiência e ao idoso com mais de 65 anos que comprovem não possuir meios de prover a própria manutenção e nem de tê-la provida por sua família. Para o recebimento deste beneficio, a renda familiar per capita deve ser inferior a 1/4 do salário mínimo e, a pessoa com deficiência, deve ser incapacitada para a vida independente e para o trabalho. Este beneficio está previsto pela Constituição Federal de 1988, e regulamentada pela Lei Orgânica da Assistência Social (LOAS), de 1993.
} 
Além dessas dificuldades, está a vinculação do PVC ao HSVP, uma vez que, o primeiro deveria estar vinculado a um serviço especializado, como um CAPS. Por isso, o PVC não recebe recursos específicos para seu funcionamento - o que otimizaria o atendimento - e não tem total autonomia para formular ações compatíveis com a proposta da Reforma Psiquiátrica, por funcionar dentro de uma instituição que ainda reproduz o modelo manicomial nos atendimentos.

A assistente social possui um amplo conhecimento e participação em eventos sobre a Reforma Psiquiátrica, inclusive como palestrante em vários deles. Sua última participação foi no treinamento do Programa Saúde da Família (PSF), onde atuou como professora. Ela entende sua atuação como uma alternativa ao modelo manicomial, pelos princípios e objetivos do PVC, inclusive com a nova proposta de transformá-lo em um Programa volante, em que as equipes de outras instituições, como dos CAPS, passariam a atender os usuários de sua cidade satélite, com a participação da assistente social, nesse primeiro momento. Atualmente, o trabalho no Paranoá já acontece dessa forma, vinculando-se o PVC ao CAPS. Assim, o serviço seria descentralizado e as equipes dos CAPS e PSF estariam preparadas para atender a essa demanda específica, que hoje fica a cargo do PVC.

Esses foram todos os programas e serviços conhecidos durante a pesquisa. Não se descarta a possibilidade de haver outras iniciativas no HSVP com o caráter psicossocial de atenção, no entanto, foram pesquisados aqueles reconhecidos como de maior relevância no hospital, indicados pelos profissionais dos serviços que já eram do conhecimento da pesquisadora.

\subsection{4 - Comparativo entre os resultados}

Finalizada a segunda parte da pesquisa, foi possível relacionar a capacitação dos profissionais em Reforma Psiquiátrica com a implementação de serviços substitutivos dentro do HSVP por iniciativa dos profissionais.

Fagundes (1992) considera que a capacitação dos profissionais que atuam na saúde mental é um importante aspecto para a implantação efetiva da Reforma a partir de novas alternativas de atendimento. Segundo a autora "a força de trabalho em saúde 
mental é constituída por pessoas e não por recursos humanos. Pessoas necessitam de capacitação, não de treinamentos”. (FAGUNDES, 1992: 63).

Tendo em vista essa perspectiva, constatou-se que algumas categorias profissionais se destacam no que diz respeito à implementação de serviços substitutivos no HSVP, conforme o quadro seguinte:

\begin{tabular}{|l|l|}
\hline \multicolumn{2}{|c|}{ Quadro 4 - Profissionais que implementaram os serviços } \\
\hline Clube dos Amigos & Assistente social \\
\hline Nacional Esporte Clube & $\begin{array}{l}\text { Assistente social e terapeuta } \\
\text { ocupacional }\end{array}$ \\
\hline Oficinas de Produção & $\begin{array}{l}\text { Terapeuta ocupacional e técnicos em } \\
\text { Enfermagem }\end{array}$ \\
\hline Setor Terapêutico Ocupacional - Internação & Terapeuta ocupacional \\
\hline Grupo de Atendimento Pós-Internação (GAPI) & Enfermeira \\
\hline Grupo de Terapia Comunitária & Enfermeira \\
\hline Programa Vida em Casa (PVC) & Assistente social \\
\hline
\end{tabular}

Os dados sobre capacitação em Reforma Psiquiátrica obtidos pelos questionários mostram que essas categorias foram as mesmas que marcaram os maiores níveis de conhecimento sobre esse tema, os quais foram 9 para a terapeuta ocupacional e as assistentes sociais, e 8,5 para os enfermeiros.

Quanto à capacitação, também estas três categorias estão entre as quatro em que todos os profissionais questionados já participaram de eventos sobre a Reforma Psiquiátrica. Estes dados se comprovam com as entrevistas realizadas com os profissionais, em que todos afirmaram já ter participado de eventos ou cursos de capacitação em Reforma Psiquiátrica.

Dessa forma, fica evidente a relação entre a capacitação e a implementação dos serviços substitutivos ao modelo manicomial. Ou seja, embora o modelo psicossocial de atenção à saúde mental no DF ainda não esteja consolidada por meio dos CAPS, Residências Terapêuticas, leitos em hospitais gerais, entre outros, a capacitação dos profissionais que atuam nessa área pode ser uma estratégia importante para a mudança do paradigma manicomial, a partir de iniciativas de serviços dentro das instituições já existentes.

Além disso, essa capacitação é responsável, em grande medida, por transformar as relações de poder dentro da instituição psiquiátrica, uma vez que "o vínculo do 
trabalhador, enquanto cidadão e profissional é com pessoas. A relação funcionáriodoença é rompida e transformada.” (FAGUNDES, 1992: 65).

Todos esses aspectos reafirmam a importância da capacitação dos profissionais que atuam na saúde mental para a construção efetiva do modelo psicossocial de atenção à saúde mental. No Brasil, existem muitos lugares onde a Reforma já está implantada de forma efetiva, e se investe em capacitação para os profissionais; esses constituem exemplos de como a Reforma Psiquiátrica pode acontecer no DF tanto por iniciativa da SES/DF, como dos profissionais das instituições psiquiátricas.

\section{4 - Acontecimentos recentes na saúde mental do DF}

A entrevista com a assistente social do PVC também forneceu dados importantes sobre a estruturação da Reforma no DF atualmente. A entrevistada conta que, recentemente, foi convidada a participar de uma audiência pública que aconteceu na Câmara dos Deputados, chamada pelo ex-coordenador da COSAM federal, com o objetivo de rever a Lei 10.216/01, que determina a mudança no paradigma do atendimento em saúde mental.

A proposta dessa revisão era desfazer a portaria que institui os CAPS como alternativa ao atendimento nessa modalidade, e voltar a centralizar a atenção à saúde mental na Psiquiatria e na medicalização. Para fortalecer essa proposta, o excoordenador formou um bloco com vários diretores de hospitais e clinicas psiquiátricas privadas, além de três deputados que defendiam a perspectiva manicomial.

O argumento desse bloco era que a lei não tinha possibilidade de ser cumprida e, por isso, deveria ser alterada. No entanto, um deputado da Região Sul criticou essa proposta, afirmando que era contraditório alterar uma lei que havia sido votada pela mesma casa; segundo ele, o problema não está na legislação, mas sim na gestão local de saúde, que pode ou não estabelecer suas ações para cumpri-la.

A assistente social entrevistada foi chamada para fazer parte do bloco que defendia a permanecia e execução efetiva da lei. No fim da audiência, não houve alteração da legislação, pois o atual coordenador da COSAM federal apresentou ao presidente da mesa um relatório sobre a implantação da Reforma Psiquiátrica, mostrando os resultados positivos já alcançados. 
O Ministério da Saúde tem mostrado a preocupação de supervisionar as ações desenvolvidas pelos CAPS, para que nesses não se reproduza a institucionalização a partir da ação dos profissionais, importante medida para transformar o modelo de atenção à saúde mental.

Em notícia de maio de 2007, publicada pelo sítio do GDF, afirma-se que o atual governador do DF está disposto a alterar o panorama da saúde mental no Distrito Federal. Entre suas ações está o investimento de R\$ 660 mil para reformar a estrutura física do prédio da internação do HSVP, que já está em andamento, cuja nova cobertura, metálica, vai abranger uma área de 3.300 metros quadrados.

Em visita ao hospital, o mesmo afirmou que pretende ampliar o quadro de profissionais do HSVP, destinando a esta unidade parte dos aprovados no concurso público da SES/DF. Além disso, declarou que vai implantar os CAPS e as residências terapêuticas nas cidades satélites, oferecendo melhores serviços de atenção aos pacientes.

De acordo com a assistente social, alguns avanços foram alcançados com relação aos CAPS, pelo compromisso de implantar a Reforma por parte de alguns profissionais; exemplo disso são os CAPS de Sobradinho e Guará (neste último, o CAPS ad), cuja direção está a cargo de duas assistentes sociais capacitadas com relação ao modelo psicossocial de atenção.

No entanto, em Brasília, a questão política ainda tem barrado a implantação da Reforma. 


\section{Considerações Finais}

Os resultados desta pesquisa permitiram, em primeiro lugar, traçar um perfil da capacitação dos profissionais do Hospital São Vicente de Paulo em Reforma Psiquiátrica, e, a partir daí avaliar como essa tem sido aplicada por meio de serviços implementados por iniciativas dos profissionais.

Foi possível perceber como esse hospital tem sido palco de grandes contradições no que diz respeito ao atendimento oferecido. Por um lado, são reproduzidas práticas tradicionalmente manicomiais, uma vez que a porta de entrada do mesmo ainda é a emergência psiquiátrica, mostrando o falho atendimento ambulatorial e comunitário na prevenção de crises. Por outro lado, alguns profissionais têm imprimido em suas ações a perspectiva psicossocial de atenção, formando equipes multidisciplinares para oferecer, aos usuários e familiares um atendimento integral em saúde mental, por meio de atividades terapêuticas e atendimento domiciliar, ações que possibilitem a (re)integração social e a participação nos processos de decisão de forma humanitária e emancipadora.

A relação que se estabelece entre a capacitação dos profissionais em Reforma Psiquiátrica e a implementação de serviços substitutivos no âmbito do Hospital São Vicente de Paulo mostra que o investimento na primeira pode ser uma alternativa de transformação do paradigma manicomial que ainda hoje norteia grande parte do atendimento em saúde mental do Distrito Federal. Os profissionais, motivados pelo conhecimento e participação no processo de implantação da Reforma Psiquiátrica, podem criar serviços por iniciativa própria, pautados no paradigma psicossocial de atenção, como tem acontecido na referida instituição.

Não obstante a existência dessas iniciativas percebe-se, no entanto, que o caráter manicomial impregnado no hospital não permite que suas ações promovam total autonomia dos usuários de forma que possam atuar como sujeitos no seu tratamento, pela institucionalização e centralidade do atendimento ao qual estão submetidos.

Dessa forma, para a implantação efetiva da Reforma Psiquiátrica no Hospital São Vicente de Paulo, é necessária uma reestruturação do atendimento, ampliando a capacidade de consultas ambulatoriais, a disposição de todos os recursos necessários à criação de novos serviços de acordo com o modelo psicossocial; mas não somente isso, também é necessário implantar a Reforma de forma concreta no Distrito Federal, 
criando leitos psiquiátricos nos hospitais gerais, Residências Terapêuticas, Centros de Atenção Psicossocial, de forma humanizada, negando o caráter manicomial do tratamento do transtorno mental, para que seja possível expandir o trabalho em redes.

Considerando as perspectivas de expansão da rede de atenção à saúde mental no Distrito Federal, a capacitação dos profissionais nesse tema torna-se novamente imprescindível, para que nos novos serviços implementados pela Secretaria de Saúde não se reproduza o modelo manicomial nas práticas dos profissionais. 


\section{Referências Bibliográficas}

AMARAL, Marcela Corrêa Martins. Narrativas de Reforma Psiquiátrica e cidadania no Distrito Federal. 2006. 204 f. Dissertação (mestrado) - Universidade de Brasília.

AMARANTE, Paulo; ROTELLI, Franco. Reformas Psiquiátricas na Itália e no Brasil: aspectos históricos e metodológicos. In: JR., Benilton Bezerra; AMARANTE, Paulo (orgs.) Psiquiatria sem hospício: contribuições ao estudo da reforma psiquiatria. Rio de Janeiro: Relume-Dumará, 1992. (p. 41-55).

BASAGLIA, Franco. As instituições da violência. In: BASAGLIA, Franco (coord.). A instituição negada: relato de um hospital psiquiátrico. Tradução de Heloisa Jahn. 3. ed. Rio de Janeiro: Edições Graal, 1985. (p. 99-133).

BRASIL. Constituição, 1988. Constituição da República Federativa do Brasil: Artigos 196 a 200.

BRASIL. Lei Orgânica da Assistência Social (1993). LOAS: lei orgânica da assistência social: legislação suplementar / Ministério da Assistência Social; 3. ed. Brasília: MAS, 2003. 72 p.

BRASIL. Ministério da Saúde. Manual do Programa “De Volta para Casa”. Brasília, 2003.

BRASIL. Ministério da Saúde. Secretaria Executiva. Legislação em saúde mental 1990-2002 / Ministério da Saúde, Secretaria Executiva - 3. ed. revista e atualizada. Brasília: Ministério da Saúde, 2002, 166 p.

CASTEL, Robert. A Ordem Psiquiátrica: a idade de ouro do alienismo / Robert Castel; tradução de Maria Thereza da Costa Albuquerque. Rio de Janeiro: Edições Graal, 1978.

COOPER, David Graham. Psiquiatria e antipsiquiatria. 2. ed. São Paulo: Perspectiva, 1989. $162 \mathrm{p}$.

COSTA, Jurandir Freire. História da psiquiatria no brasil: Um corte ideológico. Rio de janeiro: Documentário, 1976. 135 p.

DELGADO, Pedro Gabriel Godinho. Perspectivas da psiquiatria pós-asilar no Brasil. In: TUNDIS, Silvério Almeida; COSTA, Nilson do Rosário. (orgs.) Cidadania e Loucura. Políticas de Saúde Mental no Brasil. Petrópolis: Vozes, 1987. (p. 171-189).

FAGUNDES, Sandra. Saúde Mental coletiva: a construção no Rio Grande do Sul. In: JR., Benilton Bezerra; AMARANTE, Paulo (orgs.) Psiquiatria sem hospício: contribuições ao estudo da reforma psiquiatria. Rio de Janeiro: Relume-Dumará, 1992. (p. 41-55).

FILHO, João Ferreira da Silva. A medicina, a psiquiatria e a doença mental. In: TUNDIS, Silvério Almeida; COSTA, Nilson do Rosário. (orgs.) Cidadania e Loucura. Políticas de Saúde Mental no Brasil. Petrópolis: Vozes. 1987. (p. 75-102). 
GOFFMAN, Erving. Manicômios, prisões e conventos / Erving Goffman; [tradução Dante Moreira Leita]. - São Paulo: Perspectiva, 2007. - (Debates; 91 / dirigida por J. Guinsburg). - original: Asylums: essays on the social situation of mental patients and other inmates, 1961.

HSVP. Equipe do Serviço Social. O Papel do Serviço Social no HSVP. Brasília, 1994.

HSVP. Equipe do Serviço Social. Projeto Vida em Casa: Programa de Saúde Mental Domiciliar. Brasília, 2004.

HSVP. Programa Vida Em Casa. Folder do Programa. Brasília, 2007.

LOBOSQUE, Anna Marta. A luta antimanicomial: construção de um lugar. 2001. In: Revista da Saúde. Ano II - nº 2. Brasília. 2001.

MACHADO, Daniela Martins. A desconstrução do manicômio interno como determinante para a inclusão social da pessoa em sofrimento mental. 2006. $172 \mathrm{f}$. Dissertação (mestrado) - Universidade de Brasília.

MALCHER, Maria de Nazarth. Plano de atuação terapêutica nos serviços de atuação do HSVP. Brasília, s.d.

MOREIRA, Diva. Psiquiatria: Controle e repressão social. Petrópolis: Editora Vozes Ltda, 1983. $206 \mathrm{p}$

RESENDE, Heitor. Política de saúde mental no Brasil: uma visão histórica. In: TUNDIS, Silvério Almeida; COSTA, Nilson do Rosário. (orgs.) Cidadania e Loucura. Políticas de Saúde Mental no Brasil. Petrópolis: Vozes, 1987. (p. 15-73).

ROTELLI, Franco; LEONARDIS, Ota de; MAURI, Diana. Desinstitucionalização, uma outra via. In: NICÁCIO, Fernanda (org). Desinstitucionalização. São Paulo: Hucitec, 1990.

SERRANO, Alan Indio. Que é psiquiatria alternativa (o). 7. ed. São Paulo: Brasiliense, 1992. 107 p. (Coleção primeiros passos).

SISTEMA ÚNICO DE SAÚDE. Conselho Nacional de Saúde. Comissão Organizadora da III CNSM. Relatório Final da III Conferência Nacional de Saúde Mental. Brasília, 11 a 15 de dezembro de 2001. Brasília: Conselho Nacional de Saúde/Ministério da Saúde, 2002, 213 p.

TEIXEIRA, Mario. Hospício e poder. Brasília: Senado Federal, 1993. 90 p

TEIXEIRA, Sônia Fleury; MENDONÇA, Maria Helena. Reformas sanitárias na Itália e no Brasil: Comparações. In: TEIXEIRA, Sônia Fleury (org.). Reforma sanitária: Em busca de uma teoria. São Paulo: Cortez; Rio de Janeiro: Associação Brasileira de Pós-Graduação em Saúde Coletiva, 1989. 2 ed. 232 p.

VIANEY, Edilene Lima. Saúde mental do trabalhador de enfermagem em instituições psiquiátricas. 2005. 119 f. Dissertação (mestrado) - Programa 
Multiinstitucional de Pós-Graduação em Ciências da Saúde, convênio Centro-Oeste, UnB, UFG, UFMS, 2005.

Referências da Web:

AMARANTE, Paulo; TORRE, Eduardo. A constituição de novas práticas no campo da Atenção Psicossocial: análise de dois projetos pioneiros na Reforma Psiquiátrica no Brasil. In: Saúde em Debate, Rio de Janeiro, v. 25, n. 58, p. 26-34, maio/ago. 2001. Disponível em:

< http://recantodasletras.uol.com.br/arquivos/542863.pdf > . Acesso em 8 nov 2007.

BRASIL. Câmara Legislativa do Distrito Federal. Lei Orgânica do Distrito Federal. Brasília, 1993. Disponível em:<http://www.cl.df.gov.br/portal/legislacao>. Acesso em 16 nov 2007.

BRASIL. Decreto $\mathbf{n}^{\circ}$ 24.559, de 3 de julho de 1934. Dispõe sobre a assistência e proteção à pessoa e aos bens dos psocipatas. Disponível em:

<http://www.mp.ba.gov.br/atuacao/cidadania/gedef/legislacao/decreto_24_559_34.asp> Acesso em: 15 nov 2007.

BRASIL. Presidência da República. Casa Civil. Lei $\mathbf{n}^{0} 8.080$ de 19 de Setembro de 1990. Dispõe sobre as condições para a promoção, proteção e recuperação da saúde, a organização e o funcionamento dos serviços correspondentes e dá outras providências. 1990. Disponível em: <https://www.planalto.gov.br/ccivil_03/LEIS/L8080.htm>. Acesso em 10 nov 2007.

BRASIL. Presidência da República. Casa Civil. Lei n. 8142 de 28 de dezembro de 1990. Dispõe sobre a participação da comunidade na gestão do Sistema Único de Saúde - SUS - e sobre as transferências intergovernamentais de recursos financeiros na área da saúde e dá outras providências. 1990. Disponível em:

< http://www.sjc.sp.gov.br/sms/downloads/LEI8142.htm>. Acesso em 15 nov 2007.

BRASIL. Ministério da Saúde. $8^{\mathrm{a}}$ Conferência Nacional de Saúde. Relatório Final,1986. Disponível em:

<http://portal.saude.gov.br/portal/arquivos/pdf/8_CNS_Relatorio\%20Final.pdf>. Acesso em 15 nov 2007.

BRASIL. Ministério da Saúde. Portaria/GM nº 106 de 11 de fevereiro de 2000. Institui os Serviços Residenciais Terapêuticos. Disponível em:

$<$ http://200.214.130.38/portal/saude/cidadao/visualizar_texto.cfm?idtxt=23119>.

Acesso em 15 nov 2007.

BRASIL. Ministério da Saúde. Secretaria de Atenção à Saúde/DAPE. Coordenação Geral de Saúde Mental. Reforma Psiquiátrica e política de saúde mental no Brasil. Documento apresentado à Conferência Regional de Reforma dos Serviços de Saúde Mental : 15 anos depois de Caracas. OPAS. Brasília, 2005.

Disponível em: 
$<$ http://portal.saude.gov.br/portal/arquivos/pdf/Relatorio15\%20anos\%20Caracas.pdf>. Acesso em 15 nov 2007

BRASIL. Ministério da Saúde. Secretaria de Atenção à Saúde/DAPE. Saúde Mental no SUS: acesso ao tratamento e mudança do modelo de atenção. Relatório de Gestão 2003-2006. Ministério da Saúde: Brasília, 2007. Disponível em: $<$ http://portal.saude.gov.br/portal/saude/cidadao/area.cfm?id_area=925>. Acesso em: 05 dez 2007.

BRASIL. Ministério da Saúde. Portaria n. ${ }^{\circ}$ 44/GM de 10 de janeiro de 2001. Disponível em:

$<$ http://dtr2001.saude.gov.br/sas/PORTARIAS/Port2001/Gm/GM-044.htm>. Acesso em 15 nov 2007.

DELGADO, Paulo. Abaixo à Barbárie. In: Revista Cidadania. Disponível em: <http://www.paulodelgado.com.br/revista/barbarie.htm>. Acesso em 15 nov 2007.

GOVERNO DO DISTRITO FEDERAL. Secretaria de Estado da Saúde. Coordenadoria de Saúde Mental. Brasília, 2007. Disponível em:

<http://www.saude.df.gov.br/005/00502001.asp?ttCD_CHAVE=6839>. Acesso em 16 nov 2007.

GOVERNO DO DISTRITO FEDERAL. Secretaria de Estado da Saúde. Exibição de Notícia. Centro de Orientação Médico Psicopedagógico. Brasília, 2006. Disponível em:

<http://www.saude.df.gov.br/003/00301009.asp?ttCD_CHAVE=22736>. Acesso em 17 nov 2007.

GOVERNO DO DISTRITO FEDERAL. Secretaria de Estado da Saúde. Exibição de Notícia. Saúde implanta mais um Caps no DF. Brasília, 2006. Disponível em: $<$ http://www.saude.df.gov.br/003/00301009.asp?ttCD_CHAVE=44900>. Acesso em 19 nov 2007

FREITAS, Conceição. Rede pública do DF ignora doentes mentais. Correio Web. Notícias. 15 abr 2007. Brasília, 2007. Disponível em:

$<$ http://noticias.correioweb.com.br/materias.php?id=2704742\&sub=Distrito $>$. Acesso em 19 nov 2007.

GONÇALVES, Amadeu de Matos. A Doença Mental e a Cura: Um Olhar Antropológico. In: Revista do Instituto Superior Politécnico de Viseu. No 30. Millenium. Portugal. Outubro de 2004. Disponível em:

<http://www.ipv.pt/millenium/Millenium30/13.pdf>. Acesso em: 05 dez 2007.

INVERSO, Contando Nossa História. Brasília, 2007. Disponível em:

<http://www.inverso.org.br/index.php/content/view/7066.html>. Acesso em 17 nov 2007. 
MOURA, Mariluce. Os eugenistas do Brasil. Evolucionarte: Arroubos e cometimentos. 2005. Disponível em <http://maldonado.squarespace.com/os-eugenistasdo-brasil>. Acesso em 10 nov 2007.

RODRIGUES, Lorenna. Doentes mentais vivem no caos. SES/DF. Exibição de Notícia, em11 jan 2006. Disponível em:

<http://www.saude.df.gov.br/003/00301009.asp?ttCD_CHAVE=28976>. Acesso em 19 nov 2007.

SILVA, Marcos Virgílio. Detritos da civilização: eugenia e as cidades no Brasil. 2004. In: Arquitextos. Periódico mensal de textos de arquitetura. Texto Especial 235. Maio 2004. Disponível em

<http://www.vitruvius.com.br/arquitextos/arq000/esp235.asp>. Acesso em 10 nov 2007. 


\section{Apêndice}

- Questionário de pesquisa

Público-alvo: profissionais do Hospital São Vicente de Paulo

Seção de atuação no HSVP:

Profissão:

Idade: anos.

Sexo: $\square$ Feminino $\square$ Masculino

Tempo de Serviço no HSVP:

1 - Como você avalia o seu conhecimento sobre a Reforma Psiquiátrica Princípios, Legislação e Serviços Substitutivos ao modelo manicomial?

Conheço bem o assunto $\square$ Conheço de forma regular $\square$ Não conheço

Em uma escala de 1 a 10, que valor você daria para o seu nível de conhecimento sobre o assunto?

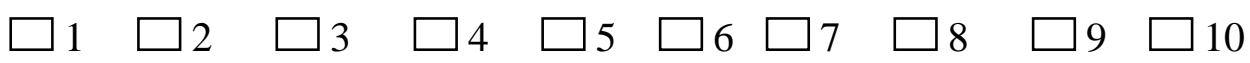

2- Você já participou de algum evento que tratasse a respeito desse tema?

$\square$ Já participei - Instituição realizadora do evento:

$\square$ Nunca participei

3- Qual o seu interesse, numa escala de 1 a 5 , em participar de um programa de capacitação sobre o tema da Reforma Psiquiátrica?

$\square 1 \quad \square 2 \quad \square 3 \quad \square 4 \quad \square 5$

4- Qual o tempo que você poderia dispor semanalmente para participar desse programa?

$\square 1$ a 2 horas $\square 2$ a 3 horas $\square 3$ a 4 horas $\square$ Nenhum 


\section{- Roteiro de entrevista semi-estruturada}

Público-alvo: profissionais que implementaram Serviços Substitutivos no âmbito no HSVP

\section{Questões:}

1- Qual é o serviço? (Nome, objetivo, como se divide).

2- Por quem foi criado? (iniciativa dos profissionais, pacientes, direção do HSVP ou da SES/DF).

3- Qual é o tempo de criação e funcionamento?

4- Existe documentação de criação? (Portarias, Planos, etc).

5- Onde ocorre?

6- Qual a periodicidade? (diário, semanal, mensal).

7- Quais são as demandas atendidas?

8- Na época de sua implementação, houve apoio do HSVP ou da SES/DF? E atualmente?

9- Como é composta a equipe atualmente?

10- Como acontecem as relações com profissionais de outras áreas? (Se há interesse ou participação de profissionais de outros setores do hospital para o desenvolvimento das atividades).

11- Quais são as dificuldades enfrentadas atualmente para o desenvolvimento das atividades?

12- Quais são os principais resultados obtidos?

13- Como você avalia o seu conhecimento a respeito da Lei 10.216/01, que determina a Reforma Psiquiátrica? Você já participou de cursos de capacitação, eventos ou palestras, a respeito desse tema?

14- Você percebe a sua intervenção, a partir desse serviço, como uma alternativa ao modelo manicomial? 